\title{
Oxidized Zinc Deposits of the United States
}

\section{Part 3. Colorado}

By ÁLLEN V. HEYL

G E O L O G I A L S U R V E Y B U L L E T I N 1135 -C

The geology of the known deposits and the resources of oxidized zinc ores in Colorado

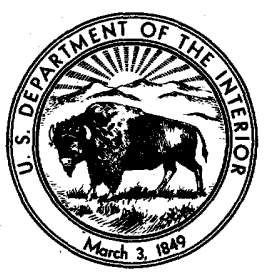




\title{
UNITED STATES DEPARTMENT OF THE INTERIOR
}

\author{
STEWART L. UDALL, Secretary
}

\section{GEOLOGICAL SURVEY}

Thomas B. Nolan, Director

The U.S. Geological Survey Library has cataloged this publication as follows: Heyl, Allen Van, 1918-

Oxidized zinc deposits of the United States. Part 3. Colorado. Washington, U.S. Govt. Print. Off., 1964. vi, 96 p. illus., maps (part fold., 2 col., part in pocket) diagrs., tables. $24 \mathrm{~cm}$. (U.S. Geological Survey. Bulletin 1135-C)

Bibliography : p. 88-91.

1. Zinc ores-Colorado. 2. Zine mines and mining-Colorado. I. Title. (Series) 


\section{CONTEN T S}

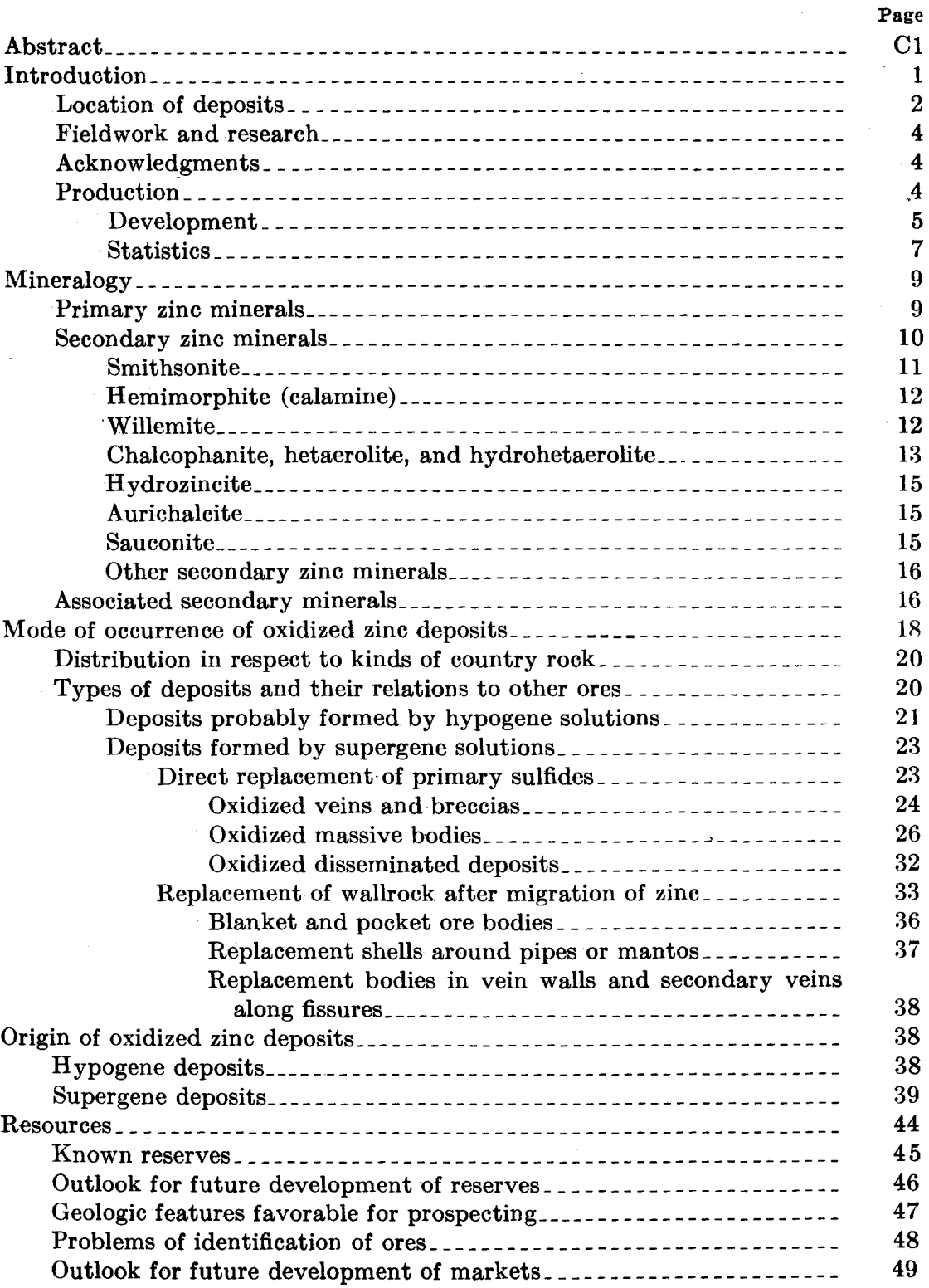


Page

Descriptive summaries of oxidized zinc deposits by districts__._.

Moffat County

Massadona-Youghall (Douglas Mountain) district_...... 50

Routt County

Hahns Peak district._... 51

Garfield County

Carbonate district.

Rifle Creek district.

Clear Creek County

Georgetown-Silver Plume district._... 55

Jefferson County

Malachite (Pipe) district.

Eagle County

Red Cliff (Gilman) district._...

Summit County

Kokomo (Ten Mile) distriat $\ldots \ldots \ldots 7$

Breckenridge district.......... 58

Pitkin County . . 59

Lenado district............. 59

Aspen district

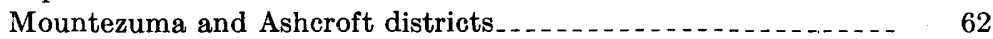

Lake County

Leadville (California) district $\ldots \ldots \ldots 2$

Mosquito Range district, including some outlying parts of the Leadville district.

Weston Pass district.

Park County

Alma (Buckskin) district.

Horseshoe district.

Gunnison County

Tomichi (White Pine) district

Quartz Creek district.

Tincup district.

Gold Brick district._._. 73

Taylor Park district._.

Spring Creek district._._._.

Rock Creek (Marble) district_._.

Chaffee County .

Monarch district. .

Chalk Creek (Romley) district.

Cottonwood Creek district

Sedalia mine

Fremont County $\ldots \ldots$

Cotopaxi district.

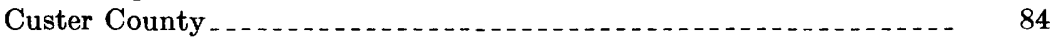

Silver Cliff, Ilse, and Rosita districts.............. 84

San Miguel County ................ 84

Placerville district

Dolores County ...

Rico district.

San Juan County .................. 86

Red Mountain and Needle Mountain districts_............. 86 
Descriptive summaries of oxidized zine deposits by districts-Con.

Mineral County ...

Sunnyside district

Creede district.

Spar district.

Costilla County

Selected references

Index .

\section{ILLUSTRATIONS}

[Plates are in pocket]

Plate 1. Map showing oxidized zine deposits of Colorado.

2. Map showing ore bodies and location of known oxidized zine deposits in Leadville mining district, Colorado.

3. Oxidized zinc deposits of the Monarch, Tomichi, and Tincup districts, Gunnison and Chaffee Counties, Colorado, and deposits in the Chalk Creek and part of the Quartz Creek and Cottonwood Creek districts.

4. Sketch map of the accessible workings of the Doctor mine, Spring Creek district, Gunnison County, Colorado.

5. Geology of the Sunshine Lode mine, Rifle Creek district, Colorado.

6. Map of the Madonna mine, Monarch, Colorado, showing the general geology of level 6 , mine workings below level 6 , and main ore bodies.

FigURe 1. Brown massive zine carbonate with hemimorphite from Leadville.

2. Hemimorphite crystal clusters, Leadville, Colo $\ldots . . . . . . .$.

3. Manganese-zinc oxides associated with other oxidized zinc minerals, and sauconite at Leadville, Colo ..............

4. Diagrammatic sections of Smuggler and Molly Gibson ore bodies at Aspen . .

5. Diagrams illustrating relation of oxidized zinc ore bodies to lead carbonate stopes in the Oro La Plata mine, Leadville..-

6. Sketch map of some of the oxidized zinc-lead deposits near Carbonate, Garfield County, Colo .....................

7. Diagrammatic sections through oxidized zinc-bearing ore bodies

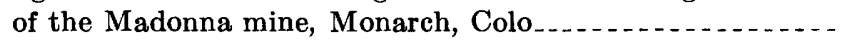




\section{TABLES}

TABLE 1. Zine production in Colorado, 1900-52

2. Generalized stratigraphic section of the Paleozoic sedimentary rocks in the Sawatch Range area

3. Analyses of oxidized zinc-lead ores, Aspen, Colo

4. Analyses of oxidized zinc-lead ores from the Tincup district...

5. Analyses of oxidized zinc ores from wallrock-replacement

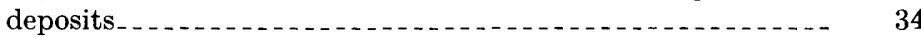

6. Recorded production of the Sunshine Lode mine

7. Production of oxidized zinc-bearing ores from several mines at Aspen and Lenado, 1911-26.

8. Oxidized zinc ores produced in the Leadville district, 1910-50_- 63

9. Production of oxidized zinc ores from Doctor mine, 1914-38_- 75

10. Range in composition of the oxidized zinc ores, Monarch district, Colorado 


\title{
OXIDIZED ZINC DEPOSITS OF THE UNITED STATES
}

\section{PART 3. GOLORADO}

\author{
By Allen V. Heyl

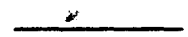

\begin{abstract}
Deposits of oxidized zinc ore are widely distributed in the western part of Colorado in the Rocky Mountains west of the Front Range and in the uplifted plateaus that border the main area of the Colorado Plateau. The principal production and reserves are restricted to several mining districts-Leadrille, Aspen, Monarch. Spring Creek, Horseshoe, Tomichi, Tincup, and Rico-in all of which limestone and dolomites of Paleozoic age are the main host rocks. One deposit, that of the Sedalia mine near Salida. has produced commercial quantities of oxidized zinc-copper ore from noncarbonate host rocks, but other known deposits in noncarbonate rocks are mostly low grade.

Oxidized zinc ore and zinc-lead ore occur, for the most part, in lead-zincsilver deposits that have been deeply oxidized. The principal ore minerals are smithsonite and hemimorphite, which are associated with smaller quantities of sauconite, hetaerolite, hydrohetaerolite, chalcophanite, hydrozincite, aurichalcite. willemite, and the secondary minerals of lead. copper. and silver. Oxidized zinc minerals directly replace primary sulfide minerals in reins, massive replacement bodies, and disseminated masses. The zine from the primars bodies may also be leached by acidic solutions of meteoric origin and migrate into the wallrock. Chemical reaction between these solutions and the limestone or feldspathic wallrocks has produced deposits of oxidized zinc minerals in blankets. pockets, veins, sheaths. and irregular bodies. A very few deposits of zinc carbonate ores are known in which the minerals may have been deposited directly from hrpogene carbonated solutions.
\end{abstract}

Not much high-grade ore (containing 25 to 50 percent zinc or at least 20 percent zinc and lead combined) remains. but large quantities of low-grade material (10 to 25 percent zinc) await better methods of beneficiation and better market conditions.

\section{INTRODUCTION}

The term "oxidized," which is used here in its geological sense, is applied to deposits or parts of deposits containing oxides, carbonates. silicates, sulfates, or vanadates of zinc which result not only from the weathering process (that is, are of supergene origin) but also from processes other than weathering (that is, are of hypogene origin). 
Although most deposits of oxidized zinc minerals in the United States are of supergene origin, a few deposits in Colorado are possibly of hypogene origin. Chemists, unlike geologists, define "oxidized" as denoting an increase in positive valence or a decrease in negative valence.

Oxidized zinc ores were first exploited in Colorado in the Aspen dis. trict about 1900. Later, in 1909, they were discovered in the walls of stopes at Leadville. These and other deposits in western Colorado were a major source of zinc for about 15 years and aided in the growth of the commercially important zinc mining and smelting industry in Colorado during the early part of the 20th century. Production of oxidized zinc ore almost ceased about 1929, and since then it has been small.

\section{IOCATION OF DEPOSITS}

Productive oxidized zinc deposits in Colorado are restricted to the Rocky Mountains west of the Front Range and to the mountains and uplifted plateaus that border the main area of the Colorado Plateau in the western part of the State (pl.1).

The principal known deposits are in the following mining districts, given in the general order of decreasing size of the oxidized zinc. deposits :

1. Leadville (San Francisco) district, Lake County

2. Aspen and Lenado districts, Pitkin County

3. Monarch district, Chaffee County

4. Spring Creek district, Gunnison County

5. Horseshoe district, Park County

6. Sedalia mine, Chaffee County

7. Creede district, Mineral County

8. Tomichi district, Gunnison County

9. Tincup district, Gunnison County

10. Rico district, Dolores County

The Leadville district is near the headwaters of the Arkansas River on the east side of the Sawatch Range, and the Monarch, Tomichi, and Tincup areas are in the southern Sawatch Range near Monarch Pass. The Monarch district is on the eastern flank of the range, and the Tomichi and Tincup districts are on the western flank.

The many mines in the Leadville district that are known to contain or to have produced oxidized zinc ores are shown on plate 2. Several other districts and the mines known to contain or to have produced oxidized zinc ores in the area of the Monarch quadrangle west of Salida are shown on plate 3 .

All the major districts except Rico and Creede lie in a nearly continuous oval belt of folded and faulted pre-Pennsylvanian Paleozoic 
limestone, dolomite, shale, and quartzite that surrounds the Sawatch Range and is elongated northwest. Large deeply oxidized zinc-rich base- and precious-metal deposits in limestone and dolomite are most abundant in this belt, and such deposits are the most favorable environment for commercial oxidized zinc ores. Also in the belt are smaller oxidized zinc deposits in ores that replace limestone in the Red Cliff (Gilman), Taylor Park, Weston Pass, Gold Brick, Cottonwood Creek, and Quartz Creek districts. One productive oxidized zinc-copper deposit, that of the Sedalia mine, is in schists of Precam. brian age in the noncarbonate core that the limestone belt encircles.

Outside the main oval limestone belt, most of the known oxidized zinc deposits are of minor commercial importance. In the San Juan Mountain area, most of the large and important lead, zinc, silver, and gold deposits are little oxidized. In a few places where oxidation is deep, such as at the Lark mine on Red Mountain, lead is the principal mineral, and the wallrocks are volcanic rocks of Tertiary age; in these places, oxidized zinc minerals, though common, occur in insufficient quantities to be potential zinc ores. At Creede, sufficient zinc is concentrated during the oxidation of the silver-lead-zinc sulfides to form zincy bodies of oxidized lead-zinc-silver ores.

To the west and northwest of the main oval belt, small oxidized zinc deposits are in outlying areas of pre-Pennsylvanian Paleozoic limestones and dolomites, as at the Montezuma mine near Ashcroft, the Snowmass Mountain area near Marble (Vanderwilt, 1937, p. 10-26), the Canbonate and Rifle Creek deposits in White River Mesa, deposits reported east of Hahns Peak (T. S. Lovering, oral communication, 1955), and the isolated mines and prospects along the south edge of Dinosaur National Monument (Untermann and Untermann, 1954, p. 10,149-152).

No occurrences of oxidized zinc minerals east and southeast of the main oval belt are of commercial size except a few deposits in the Alma district on Mount Bross and Mount Lincoln and local pockets of oxidized lead-zinc-silver ores in the Silver Cliff district.

The Precambrian gneisses and schists which form the core of the Front Range, Colo., are unfavorable host rocks for oxidized zinc deposits, even though many of the metal deposits in this eastern part of the Colorado Mineral Belt contain zinc and are deeply oxidized. The most notable of the many small deposits are at the Defender and Bull Domingo mines in the Silver Cliff district, where smithsonite is deposited in lead-silver carbonate ores in gneisses and felsic volcanic rocks (Lindgren, 1908, p. 169), and at the Augusta mine south of Evergreen, where willemite was noted with supergene copper and lead minerals in a fluorite-barite vein in gneiss of Precambrian age (Pough, 1941, p. 92). 


\section{FIELDWORK AND RESEARCH}

This report is a compilation of data available on the oxidized zinc deposits of Colorado; consequently, it contains information from many sources including field examinations, published literature, mining companies, and individuals. Other reports produced by this study are listed under Heyl and under Heyl and Bozion in the "Selected references" (p. C89). Loughlin $(1918,1926)$ and Emmons, Irving, and Loughlin (1927) spent many years studying the Leadville ore deposits, especially the oxidized zinc ores, and their reports are principal sources of information. Recent studies of districts that contain oxidized zinc deposits include those by Behre (1953), Singewald and Butler (1941), and Dings and Robinson (1957). Many mineral occurrences of oxidized zinc minerals are listed by Eckel (1961).

Most of the deposits were visited by the author during the summers of 1954, 1955, and 1956 as part of a regional study of oxidized zinc deposits in the Western States. C. N. Bozion and Priestley Toulmin, 3d, ably helped with the field examinations. T. S. Lovering, C. S. Robinson, A. L. Bush, T. A. Steven, Q. D. Singewald, Ogden Tweto, M. R. Brock, W. S. Burbank, and M. G. Dings, all of the U.S. Geological Survey, were especially helpful and provided much useful information, constructive discussion, and aid in field examinations in districts which they were mapping. Studies of some of the oxidized minerals in the Sedalia mine were conducted by Mary E. Mrose.

\section{ACKNOWLEDGMENTS}

The freely given cooperation of the many mining companies, mine owners, operators, and consulting geologists greatly aided in the study. The writer is particularly indebted to Mr. H. W. Pinger, consulting geologist; Mr. S. E. Jerome, geologist, Gulf Minerals; Prof. C. H. Behre, Jr., Department of Geology, Columbia University; Messrs J. H. and William Herron, mine owners, Aspen; Mr. A. L. Pearson, mine owner, Pitkin; Mr. S. Jackson, Creede; Mr. John Sondheim, superintendent, Bonanza Consolidated Mining Co.; Mr. J. H. Ratliff, Vernal, Utah; Mr. W. I. Hoklass, Steamboat Springs, Colo.; Mr. Frank Hoheizel, Gunnison; Mr. Sherman Hinckley, general manager, Rico Argentine Mining Co.; Mr. John Lambertson, mine operator, Italian Peak; Messrs A. J. Martin, Paul Luff, and John Kelley, U.S. Bureau of Mines; Mr. Lale Harmon, mine operator, and Mr. H. R. Koster, treasurer, Utze Lode Co.

\section{PRODUCTION}

Colorado has been among the chief zinc-producing States in the country for many years. It was third in zinc production in 1952, 
when it produced 53,203 short tons of recoverable zinc metal from its mines (U.S. Bureau of Mines, 1952). By 1954 its production had sharply declined to 35,150 short tons of zinc, and its position nationally as a source of primary zinc had dropped to fifth largest (U.S. Bureau of Mines, 1954). Between 1858 and 1952, inclusive, Colorado produced $1,625,503$ short tons of zinc metal valued at $\$ 287,424,322$. Since 1941 the Gilman (or Eagle) mine of the Empire (New Jersey) Zinc Co. has been by far the main producer.

During the first part of the 20th century, much of the zinc produced in Colorado came from oxidized zinc or zinc-lead ores (table 1). In the decade 1911-21, from 10 to nearly 50 percent of the metallic zinc came from this source-much of it from Leadville, but also notable quantities from the Monarch, Spring Creek, Aspen, and Horseshoe districts and the Sedalia mine.

\section{DEVELOPMENT}

Oxidized zinc ores were first reported in Colorado in 1882 "**** in the vicinity of Leadville $* * * "$ by . Konig (Loughlin, 1918, p. 8 ). The ores were not of commercial value at that time because they were too far west to be shipped to the eastern markets at a profit, and no interest in them was developed until many years later. Production of zinc sulfide ores began in 1885 from Clear Creek, Lake, and Summit Counties (Henderson, 1926, p. 82). However, during the 19th century, zinc was " $* * *$ considered something to be avoided and cursed when found with other ores; often called 'poison' by operators $* * *$ " of mines and mills (Henderson, 1926, p. 11). Major production of zinc sulfide ores began in 1899 from the Leadville, Creede, and Georgetown districts (Henderson, 1926, p. 12).

The two main silver-bearing ore bodies in the Smuggler and Molly Gibson mines, two of the largest ore bodies at Aspen, grade up-plunge into low-grade oxidized zinc ore (Spurr, 1898, p. 193) that contains lead and, locally, silver in economic quantities. By 1900 the rich silver ores had been mined out, and the parts of these zinc ore bodies that contained 4 to 6 ounces per ton of silver were being mined selectively (Hodges, 1901, p. 128-131; 1902, p. 136-139). The ores were finely ground and were concentrated by gravity methods into silver-lead and zinc-silver-lead concentrates. The silver-lead concentrates were sold immediately, but the zinc-silver-lead concentrates were collected in slime ponds; later, from 1904 to 1908, they were shipped to Canon City, where they were used for zinc-lead pigments. Several million pounds of zinc was produced from these ores, which constituted the first mine production of zinc-oxide ores in Colorado.

The first oxidized zinc ores that were mined and shipped immediately in Colorado were produced in the Monarch district from 
the Madonna, Monarch Pool, and Eclipse mines. The reported date of shipment varies. J. B. McDonald (oral communication to G. F. Loughlin, pre-1918, in Loughlin, 1918, p. 12) states that several hundred tons of zinc silicate ore was shipped from the Madonna mine in 1902 and that mixed zinc carbonate and silicate ores were shipped from the Eclipse mine by Mr. Harry Paul and himself in 1903. Henderson (1926, p. 107) reports that zinc was produced in 1903 in Chaffee County, partly verifying McDonald's statements; but Craw. ford $(1913$, p. 250), in his comprehensive report on the Monarch district, mentions that the Paul brothers were producing oxidized zine ores from the Eclipse mine in 1905-06, and he infers that this was the first production of these ores. Although he does not credit the Madonna mine with production of oxidized zine ores until 1906, Crawford notes elsewhere in his report that the records of many of the Monarch mines were incomplete.

Loughlin (1918, p. 12) states that McDonald in the spring of 1906 found oxidized zinc ores at the Hill Top mine, Horseshoe district, Park County. From 1907 to 1916, inclusive, large quantities of these ores were produced from the mine. From 1907 to 1910, oxidized zinc ores were produced from the mines previously mentioned and from the Morning Star and Victor mines, Tomichi district; the Doctor mine, Spring Creek district; the Silent Friend, Great Monarch and Wilson mines, Monarch district; the Nelson mine, Alma district; and possibly from the Rock Creek district near Marble. In 1907, copper-zinc ore from the Sedalia mine near Salida was shipped to the Canon City zinc-lead paint plant, which used the zinc for paint and smelted the residues for copper matte (Lindgren, 1908, p. 161).

The first high-grade oxidized zinc ore body found at Leadville (pl. 2) was hemimorphite ore, which was discovered at the May Green mine and was shipped in 1910 by H. E. Burton, H. K. White, and Alfred Thielen (Loughlin, 1918, p. 12-13). D. S. Nicholson, manager of the Western Mining Co., then found the largest bodies of oxidized zinc ore known in the district. These discoveries started a general search for such ore throughout the Leadville and nearby districts, and it was found and mined on many properties from 1910 to 1927, inclusive (Emmons, Irving, Loughlin, 1927). Most of the zinc ore mined in Leadville from 1910 to 1920 was oxidized and apparently was mined at a profit.

Discovery of large ore bodies and production of oxidized zinc ore at Leadville stimulated greatly the search elsewhere in Colorado after 1910. In addition to the districts previously described, the Red Cliff district, the Doctor mine in the Spring Creek district, the Lenado district, the Sedalia mine near the Turret district, the Tincup, Pitkin, Weston Pass districts, and possibly the Massadona district on the 
Yampa River all produced some oxidized zine ore between 1911 and 1925. The Aspen, Monarch, and Spring Creek, districts in particular, continued to be major but little-known producers of oxidized ores.

The Western Zinc Mining and Reducing Co. erected a zinc oxide plant in 1914 at Leadville that was designed to treat zinc carbonate ore containing 16 percent or less zinc. It was operated for only a short time in 1914, but the following year it was successfully operated by the Western Zinc Oxide Co. and produced 150 tons per month of a product that contained 70 to 80 percent zinc and sold for $\$ 100$ a ton. This plant was enlarged and operated successfully until 1926, when it was closed because of lack of ore rather than economic failure of the plant. During this same period, Colorado was briefly the center of a major zinc-smelting industry. Zinc smelters were in operation at intervals at Pueblo, Salida, Canon City, and Florence, as were two zinc oxide plants at Canon City and one at Leadville. Coal and flux supplies are abundant nearby. The closing of these plants in later years made zinc mining a much less profitable venture in the Rocky Mountains because of the greatly increased costs of shipping ore and concentrates to distant smelters in Utah, Idaho, Texas, or central States and the decrease in competitive pricing in the refining industry; so, once again, zinc became a less desirable metal in many Colorado ores.

By 1926, most of the higher grade oxidized zinc ores that were known in Colorado had been mined, and market conditions for both the ores and zinc oxide were much less favorable. The Leadville oxide plant was closed in that year, and the industry rapidly declined (table 1). Practically no oxidized zinc ore was produced during the depression years of 1929-36, but since then a small tonnage has been produced annually and shipped to eastern oxide plants or to zinc smelters that have fuming plants in other States.

Although zinc is still produced in quantity in Colorado, nearly all of it is from sufide ores, and it is almost entirely a not-very-profitable byproduct that is concentrated during the milling of silver-lead-zinc ores. The only recently active base-metal smelter in Colorado is the Arkansas Valley lead-silver smelter at Leadville; consequently, all kinds of zinc ore have to be shipped out of the State. Zinc concentrates from Gilman are roasted and separated magnetically at the former Empire zinc smelter at Canon City, but the rest of the smelting operations are completed east of the Mississippi River.

\section{STATISTICS}

Table 1 shows the production of zinc in Colorado and, incompletely, the production of oxidized zinc ores. The production of oxidized zinc ores has been published with that of sulfide zinc ores without distinction except at Leadville in the period from 1910 to 1930 (Henderson, 
TABLE 1.-Zinc production in Colorado, 1900-52

[Data compiled from U.S. Geol. Survey (1900-23), U.S. Bur. Mines (1924-31), U.S. Bur. Mines (1932-52) Henderson (1926), Emmons, Irving, and Loughlin (1927)]

\begin{tabular}{|c|c|c|c|c|c|c|}
\hline Years & $\begin{array}{l}\text { Total zinc } \\
\text { ore and } 7 \text { inc- } \\
\text { lead ore } \\
\text { sold or } \\
\text { treated } \\
\text { (short tons) }\end{array}$ & $\begin{array}{l}\text { Oxidized } \\
\text { zinc ore and } \\
\text { oxidized } \\
\text { zinc-lead ore } \\
\text { sold or } \\
\text { treated } \\
\text { (short tons) }\end{array}$ & $\begin{array}{l}\text { Average } \\
\text { grade of } \\
\text { oxidized } \\
\text { zinc ore and } \\
\text { zinc-lead } \\
\text { ore } \\
\text { (percent } \mathrm{Zn} \text { ) }\end{array}$ & $\begin{array}{l}\text { Recoverable } \\
\text { metallic zinc } \\
\text { in oxidized } \\
\text { zinc ore and } \\
\text { oxidized } \\
\text { zinc-lead ore } \\
\text { (short tons) }\end{array}$ & $\begin{array}{l}\text { Recoverable } \\
\text { metallic } \\
\text { zinc in } \\
\text { all ores } \\
\text { (short tons) }\end{array}$ & $\begin{array}{l}\text { Total value } \\
\text { zinc in } \\
\text { all ores }\end{array}$ \\
\hline $\begin{array}{l}1900-04 \\
1905 \\
1906 \\
1907 \\
1908 \\
1909 \\
1910 \\
1911 \\
1913 \\
1914 \\
1915 \\
1916 \\
1917 \\
1918 \\
1920 \\
1921 \\
1922 \\
1923 \\
1924 \\
1925 \\
1926 \\
1927 \\
1928 \\
1929 \\
1930 \\
1935 \\
1940 \\
1945 \\
1950\end{array}$ & \begin{tabular}{l}
\multicolumn{1}{l}{$(1)$} \\
$(1)$ \\
218,826 \\
350,422 \\
241,517 \\
226,206 \\
326,655 \\
325,230 \\
407,071 \\
344,662 \\
313,289 \\
384,373 \\
442,986 \\
552,826 \\
351,546 \\
116,667 \\
281,670 \\
9,905 \\
65,728 \\
307,185 \\
369,099 \\
459,897 \\
503,791 \\
509,071 \\
492,593 \\
458,251 \\
716,986 \\
243,179 \\
$2,804,365$ \\
$2,942,112$ \\
$3,070,177$
\end{tabular} & $\begin{array}{r}(2) \\
(2) \\
2923 \\
410,000 \\
4700 \\
(1) \\
413,000 \\
485,000 \\
5144,482 \\
5137,240 \\
5114,860 \\
589,697 \\
596,648 \\
579,847 \\
527,838 \\
521,832 \\
619,404 \\
5,677 \\
11,707 \\
20,513 \\
18,801 \\
712,294 \\
78,616 \\
392 \\
(8) \\
\text { None } \\
(8) \\
10641 \\
114,615 \\
112628 \\
11413\end{array}$ & $\begin{array}{l}(2) \\
(2) \\
234.04 \\
(1) \\
(1) \\
(1) \\
(1) \\
(1) \\
529.2 \\
527.49 \\
524.34 \\
623.18 \\
522.24 \\
520.87 \\
521,57 \\
(1) \\
(1) \\
40.66 \\
21.64 \\
20.84 \\
19.45 \\
720.9 \\
719.4 \\
22.56 \\
(8) \\
\text { None } \\
(9) \\
(1) \\
(1) \\
(1) \\
(1)\end{array}$ & $\begin{array}{l}\text { (2) } \\
(2) \\
23236 \\
(1) \\
(1) \\
(1) \\
(1) \\
(1) \\
3531,600 \\
3528,200 \\
3517,700 \\
(1) \\
(1) \\
512,926 \\
54,829 \\
52,655 \\
(1) \\
\\
2930 \\
2,027 \\
3,421 \\
2,898 \\
72,041 \\
71,320 \\
\text { (8) } 71 \\
\text { (8) } \\
\text { None } \\
\text { (8) } \\
10102 \\
11579 \\
11297 \\
1174\end{array}$ & $\begin{array}{r}121,584 \\
41,781 \\
43,006 \\
42,524 \\
15,065 \\
25,605 \\
38,545 \\
47,304 \\
66,112 \\
59,673 \\
48,387 \\
52,297 \\
67,143 \\
60,158 \\
44,567 \\
18,610 \\
24,395 \\
1,180 \\
11,629 \\
27,076 \\
28,364 \\
30,811 \\
32,500 \\
35,865 \\
35,731 \\
29,431 \\
54,566 \\
13,004 \\
137,956 \\
203,532 \\
154,693\end{array}$ & $\begin{array}{r}\$ 12,099,581 \\
4,930,123 \\
5,246,787 \\
5,017,865 \\
1,416,110 \\
2,765,354 \\
4,162,841 \\
5,392,625 \\
9,123,374 \\
6,683,400 \\
4,935,523 \\
12,969,799 \\
17,994,252 \\
12,272,209 \\
8,111,185 \\
2,717,096 \\
3,952,050 \\
118,000 \\
1,325,706 \\
3,682,336 \\
3,687,255 \\
4,683,196 \\
4,875,000 \\
4,590,656 \\
4,359,182 \\
3,884,826 \\
4,891,850 \\
1,372,450 \\
27,621,894 \\
50,267,916 \\
50,943,676\end{array}$ \\
\hline $1900-52 \ldots$ & $1417,836,285$ & 12948,000 & $1319.4-40.66$ & 12167,000 & $1,613,094$ & $286,094,117$ \\
\hline
\end{tabular}

1 Not recorded.

2 A large tonnage of zinc-lead-silver oxidized ore was produced at Aspen from 1900 to at least 1904. Silver-lead concentrates were marketed in the years mined, but the zincsilver-lead concentrates were stored and marketed in 1904-08. The zinc-silver-lead concentrates yielded several million pounds of zinc, but exact production is not known. Oxidized zinc ore production was also reported from the Madonna, Monarch Pool, and Eclipse mines during 1902-05 in substantial tonnages. Listed 1906-08 data are from the latter mines only and do not include production from Aspen.

3 Estimated from known production on a basis of 75-percent recovery.

4 Estimated from semicomplete production data.

5 Does not include a small but commercially important production from Smuggler, Durant, Late Acquisition, and Great Western mines, Aspen, at intervals during the years 1912-19.

6 Not total, as some additional oxidized zinc-lead ores are known to have been produced.

7 Includes State production as recorded in Mineral Resources for 1925 and 1926, plus an appreciable tonnage of silver-bearing zinc oxide ore from Aspen. Estimated zinc-metal content of that ore is based on a 70-percent recovery.

8 A small tonnage of custom-treated zinc carbonate ore was shipped to Leadville smelter.

${ }^{\ominus}$ None reported in these years.

10 Incomplete data. Figure is for years 1937-38 and may include a little zinc sulfide ore. Some ore was produced in 1936 and 1939 from Leadville. None was produced in 1935.

11 May include some zinc sulfide ores. In 1948 and 1949 some additional oxidized zinclead ores were probably produced.

12 Total short tons of ore and metal produced including estimates for the missing data based on data that is available. Should be used only to indicate approximate order of magnitude of total production.

${ }^{13}$ Minimum and maximum range in grade. Data too incomplete to estimate average grade of total; best guess by author would be about 24 percent.

14 1906-52, inclusive. Because of lack of data, total does not include the years 1900-05, inclusive. 
1926, p. 164-175 ; U.S. Geological Survey, 1910-23 ; and U.S. Bureau of Mines, 1924-30). In recent years the U.S. Bureau of Mines has not distinguished between oxidized and unoxidized ores. The table is thus incomplete for other years and for other districts, including such major ones as Monarch, Spring Creek, Aspen, and Horseshoe.

\section{MINERALOGY}

Many of the minerals in the oxidized zine deposits in Colorado are listed below, including the main primary minerals from which the secondary minerals are derived and with which they may be associated if oxidation is not complete. All the known secondary zinc minerals are listed in the relative order of their abundance; also listed are the principal secondary minerals of other metals deposited with the zinc minerals. At least one-half of the associated minerals listed are common to most oxidized zinc deposits, and the others are abundant in some localities.

\section{Main primary minerals}

Ore and sulfide minerals:

Galena [PbS]

Sphalerite [ZnS]

Pyrite $\left[\mathrm{FeS}_{2}\right]$

Chalcopyrite $\left[\mathrm{CuFeS}_{2}\right]$

Pyrrhotite $\left[\mathrm{Fe}_{1-x} \mathrm{~S}\right]$

Argentite $\left[\mathrm{Ag}_{2} \mathrm{~S}\right]$

Polybasite [ $(\mathrm{Ag}, \mathrm{Cu})_{18} \mathrm{Sb}_{2} \mathrm{~S}_{11}$ ]

Pearceite [( $\left.\mathrm{Ag}, \mathrm{Cu})_{18} \mathrm{As}_{2} \mathrm{~S}_{11}\right]$

Magnetite $\left[\mathrm{Fe}_{3} \mathrm{O}_{4}\right]$

Hematite $\left[\mathrm{Fe}_{2} \mathrm{O}_{3}\right]$

Tennantite $\left[(\mathrm{Cu}, \mathrm{Fe})_{12} \mathrm{As}_{4} \mathrm{~S}_{13}\right]$

Gold [Au]

Bismuthinite $\left[\mathrm{Bi}_{2} \mathrm{~S}_{3}\right]$

Tetrahedrite $\left[(\mathrm{Cu}, \mathrm{Fe}){ }_{12} \mathrm{Sb}_{4} \mathrm{~S}_{13}\right]$

Bornite $\left[\mathrm{Cu}_{5} \mathrm{FeS}_{4}\right]$

Pyrargyrite [ $\mathrm{Ag}_{,} \mathrm{SbS}_{3}$ ]

Gahnite $\left[\mathrm{ZnAl}_{2} \mathrm{O}_{4}\right]$

Zincian siderite [ $(\mathrm{Fe}, \mathrm{Zn}) \mathrm{CO}_{3}$ ]

Helvite [ $(\mathrm{Mn}, \mathrm{Fe}, \mathrm{Zn})_{4} \mathrm{Be}_{3} \mathrm{Si}_{3} \mathrm{O}_{12} \mathrm{~S}$ ]

Genthelvite [ $\mathrm{ZnBe}_{3} \mathrm{Si}_{3} \mathrm{O}_{12} \mathrm{~S}$ ] ngue minerals:

Dolomite $\left[\mathrm{CaMg}\left(\mathrm{CO}_{3}\right)_{2}\right]$

Quartz and jasperoid $\left[\mathrm{SiO}_{2}\right]$

Siderite $\left[\mathrm{FeCO}_{3}\right]$

Manganosiderite [ $(\mathrm{Fe}, \mathrm{Mn}) \mathrm{CO}_{3}$ ]

Barite $\left[\mathrm{BaSO}_{4}\right]$

Calcite $\left[\mathrm{CaCO}_{3}\right]$

Sericite $\left[\mathrm{KAl}_{3} \mathrm{Si}_{3} \mathrm{O}_{10}(\mathrm{OH})_{2}\right.$ ]

Kaolinite $\left[\mathrm{Al}_{2} \mathrm{Si}_{2} \mathrm{O}_{5}(\mathrm{OH})_{4}\right]$

Alunite $\left[\mathrm{KAl}_{5}\left(\mathrm{SO}_{4}\right)_{2}(\mathrm{OH})_{8}\right]$

Chlorite [ $(\mathrm{Mg}, \mathrm{Fe})_{5}\left(\mathrm{Al}, \mathrm{Fe}^{+3}\right)_{2} \mathrm{Si}_{3} \mathrm{O}_{10}$ $\left.(\mathrm{OH})_{8}\right]$

Tremolite $\left[\mathrm{Ca}_{2} \mathrm{Mg}_{5} \mathrm{Si}_{8} \mathrm{O}_{22}(\mathrm{OH})_{2}\right]$

Garnet $\left[\mathbf{R}_{3}^{+2} \mathbf{R}_{2}^{+3}\left(\mathrm{SiO}_{4}\right)_{3}\right]$

Actinolite $\left[\mathrm{Ca}(\mathrm{Mg}, \mathrm{Fe})_{5} \mathrm{Si}_{8} \mathrm{O}_{22}(\mathrm{OH})_{2}\right]$

Halloysite $\left[\mathrm{Al}_{2} \mathrm{Si}_{2} \mathrm{O}_{5}(\mathrm{OH})_{4} \cdot \mathrm{H}_{2} \mathrm{O}\right]$

Rhodocrosite $\left[\mathrm{MnCO}_{3}\right]$

Albite $\left[\mathrm{NaAlSi}{ }_{3} \mathrm{O}_{8}\right]$

Serpentine $\left[\mathrm{Mg} \mathrm{Si} \mathrm{S}_{2} \mathrm{O}_{5}(\mathrm{OH})_{4}\right]$

Ankerite $\left[\mathrm{Ca}(\mathrm{Fe}, \mathrm{Mg})\left(\mathrm{CO}_{3}\right)_{2}\right]$

Fluorite $\left[\mathrm{CaF}_{2}\right]$

\section{PRIMARY ZINC MINERAIS}

Sphalerite, the isometric zinc sulfide, is the only commercially valuable primary zinc mineral in Colorado, and it is the source of the oxidized zinc deposits in the State. Sphalerite is very common in many base- and precious-metal deposits, and lead-silver deposits completely free of sphalerite are uncommon.

Sphalerite commonly contains some iron, manganese, cadmium, and germanium as isomorphous constituents. Chalcopyrite, galena, pyrite, and stannite are common impurities, the chalcopyrite and stannite as oriented inclusions within the sphalerite. Native gold 
(Emmons, Irving, and Loughlin, 1927, p. 168) and silver are reported as constituents in some places; the form of the silver is not known. Sphalerite is one of the most easily oxidized sulfides. Iron-rich sphalerites are much less resistant to oxidation than are the zinc-rich varieties, and many of the sphalerites in Colorado are iron rich-in places, as at the Sedalia mine, reaching marmatite.

Other zinc-bearing hypogene (or probably hypogene) minerals, of mineralogic interest only or as contributing ore minerals, are (1) gahnite, a zinc spinel found as green crystals and grains in sphalerite and galena veins and in garnet gneiss gangue at the Bon Ton mine near Maysville, Monarch district (Crawford, 1913, p. 205, 280), at the Cotopaxi mine at Cotopaxi, and at the Sedalia mine near Salida; (2) helvite, an uncommon contact metamorphic mineral containing some zinc that is found locally near Ouray in the San Juan Mountains (Robert Luedke, oral communication, March 1957) and at Sunnyside in the Silverton district (Burbank, 1933, p. 513-527), and genthelvite, the zinc end member of the helvite group that is a rare mineral in the Sangre de Cristo Range (Eckel 1961, p. 180) ; and (3) zincian siderite, containing as much as 9.3 percent zinc, which is deposited with pyrite in fissure veins cutting a massive sulfide ore body at the F. M. D. mine near Evergreen (Lindgren, 1908, p. 168). Zinc, probably in the form of smithsonite, is a minor constituent of the possibly hypogene lead carbonate deposits of Ilse and the Lark mine.

\section{SECONDARY ZINC MINERALS}

The principal secondary zinc minerals found in Colorado are listed below, in order of their decreasing abundance.

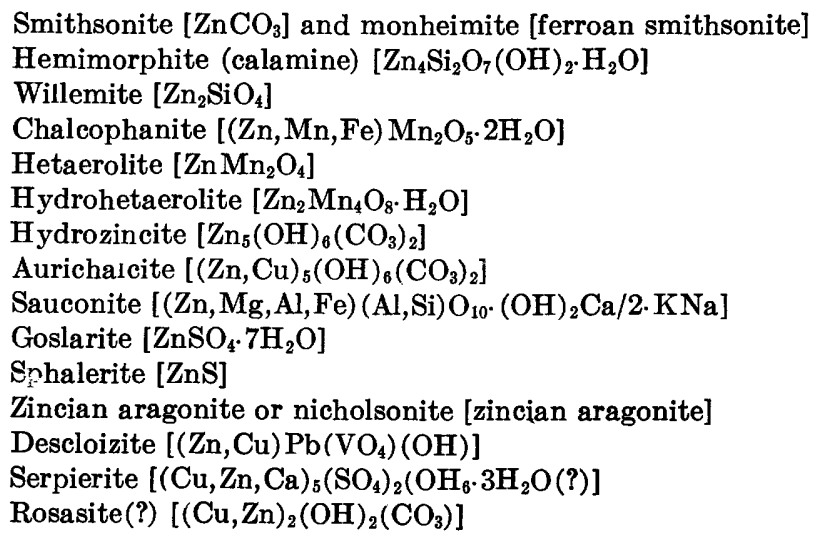

Smithsonite and hemimorphite are the main oxidized zinc minerals in Colorado. Chalcophanite, hydrohetaerolite, and aurichalcite have been produced for their zinc content at Leadville, and hydrozincite 
is a major constituent of the oxidized zinc ores in the northwestern part of the State and at the Sedalia mine. Sauconite may occur in quantities large enough to be considered ore bodies at Leadville, but it is questionable whether the zinc can be recovered at a profit by methods known at present (1963). Willemite at the Sedalia mine is locally sufficiently abundant to be a contributing ore mineral, and supergene sphalerite is a similar constituent of the ores at Aspen.

\section{SMITHSONITE}

Smithsonite, the carbonate of zinc (and a ferroan variety of it that approaches monheimite), is the most abundant oxidized zinc mineral in Colorado. Much of it is in dense gray, brown, or red granular masses that resemble impure weathered limestone (fig. 1) or in porous, spongy, drusy crystalline incrustations which, very locally, may grade into pale-green or white translucent reniform crystalline crusts. The crystalline crusts approach pure smithsonite,

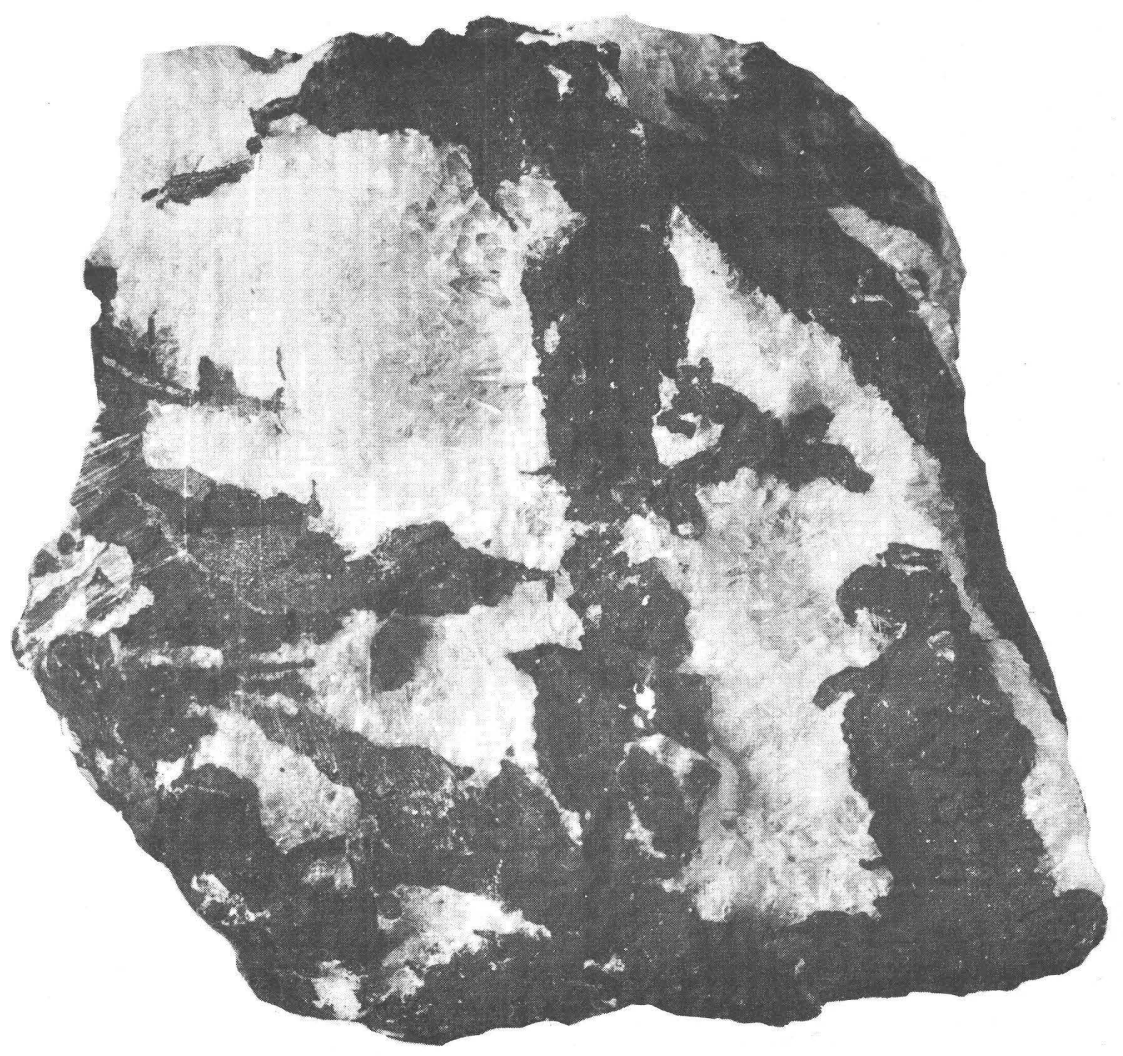

FIGURE 1.-Brown massive zinc carbonate with cavities filled with druses of hemimorphite, Leadville, Colo. From Loughlin (1918, pl. 4A). 
which contains 52 percent metallic zinc; the other much more abundant varieties contain from 15 to 45 percent zinc, owing to isomorphous mixtures of ferrous iron and manganese, and closely associated minerals such as limonite, quartz, chalcophanite, and psilomelane. Most of the smithsonite shipped as ore in the past contained from 25 to 48 percent zinc. Much of the unmined mineral contains only 10 to 20 percent zinc, but some contains enough lead, silver, copper, manganese, or gold to add to its value. Eckel (1961, p. 305) lists a few localities for smithsonite not noted in this report.

The various habits of smithsonite have been described by Loughlin (1918, p. 17-18). They are briefly listed below in their general sequence of deposition:

1. Direct replacements of the primary sphalerite and gangue carbonate minerals as fine cellular boxworks or massive pseudomorphs.

2. Massive, coarsely cellular, and curved lamellar replacements of the limestone and dolomite wallrocks (fig. 1).

3. Banded mammillary, drusy, and fibrous masses, as well as coarse crystals in fractures and vugs that, more commonly than the other varieties ,are colorless, white, pale green, or blue.

\section{HEMIMORPHITE (CALAMINE)}

The mineral hemimorphite, if pure, contains 54.2 percent metallic zinc. It occurs typically in clusters of small colorless, white, or gray bladed and sheaflike crystals (fig. 2); it also occurs in dirty gray or brown porous masses or aggregates of small radiating crystals, commonly mixed with remnants of galena, limonite, jasperoid, cerussite, manganese oxides (fig. $3 A$ ), and, in places, cerargyrite. Hemimorphite is common in Colorado and occurs in commercial quantities in many places, but it is not as abundant as smithsonite at most localities. Eckel (1961, p. 182,360-361) describes a few localities for hemimorphite not noted in this report.

Hemimorphite commonly replaces the primary sulfide ores as they oxidize or is deposited in crusts, fills fractures, or lines vugs in smithsonite (fig. 1) or in limonite, hydrozincite, quartz, and calcite formed by the weathering of smithsonite. A more complete description is given in a report on oxidized zinc deposits in Utah (Heyl, 1963).

\section{WILLEMITE}

Willemite in small white, gray, and pale-brown tabular crystals and hexagonal prisms is one of the early supergene minerals deposited in schists of Precambrian age at the Sedalia mine, north of Salida. The small crystals are coated with ferroan smithsonite, hydrozincite, and other oxidation products. Willemite is abundant enough to be at least a contributing mineral in the oxidized zinc ores of the deposit. The mineral was first described by Penfield (1894). 


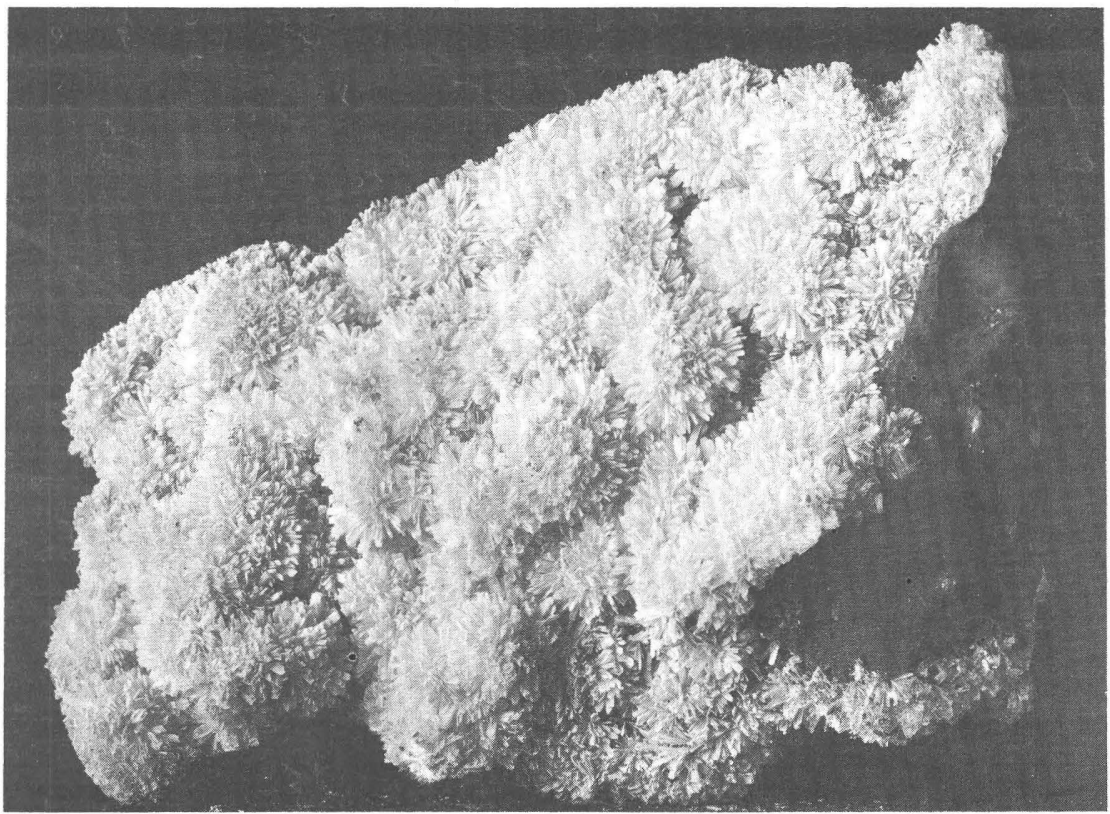

FIgURE 2.-Hemimorphite showing typical radiating crystal clusters, Leadville, Colo. From Loughlin (1918, pl. $4 B$ ).

Willemite is deposited in small quantities at the Augusta mine at Evergreen (Pough, 1941, p. 97) as small black prismatic crystals associated with azurite, malachite, cerussite, and barite in pockets in a thin copper-silver-crustified quartz-fluorite vein in rocks of Precambrian age (Lovering and Goddard, 1950, p. 279).

\section{CHALCOPHANITE, HETAEROLITE, AND HYDROHETAFROLITE}

These three maganese-zinc oxides are widespread at Leadville in close association with the other oxidized zinc minerals; locally, as at the Wolftone mine, they are abundant enough to have been produced as zinc ores. Hydrohetaerolite was described in detail as "hetaerolite" or "wolftonite" by Loughlin (1918, p. 21-23), and chalcophanite was described by Emmons, Irving, and Loughlin (1927, p. 159-160). When pure, hydrohetaerolite contains about 37.5 percent $\mathrm{ZnO}$ and chalcophanite contains about 21 percent $\mathrm{ZnO}$. Hewett and Fleischer (1960, p. 8,12-13) had X-ray analyses made of Leadville material and found that hetaerolite is more abundant than hydrohetaerolite. All three minerals closely resemble the manganese oxides pyrolusite and psilomelane, which are also abundant at Leadville in oxidized ores other than those of zinc; but chalcophanite, at least, has a distinctive blueblack color and occurs in mammillary crusts (fig. $3 A$ ). Probable zincian manganese oxides were noted by the author also in the Mon- 


\section{C14 OXIDIZED ZINC DEPOSITS OF THE UNITED STATES}
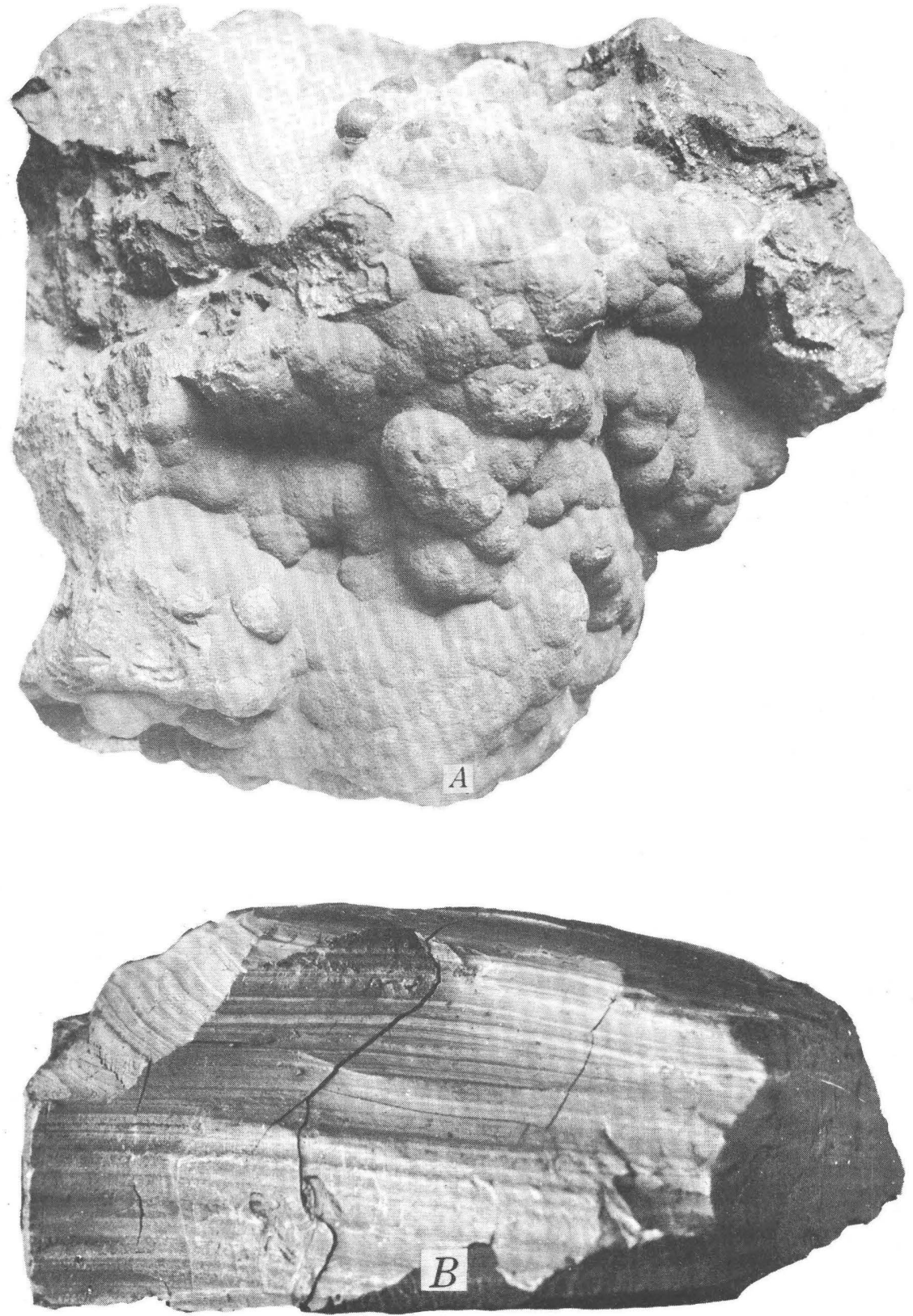

FIGURE 3.-Manganese-zinc oxides associated with other oxidized zinc minerals, and sauconite at Leadville, Colo. A, Chalcophanite and hemimorphite coating brown zinc carbonate ore (from Loughlin, 1918, pl. $1 B$ ); $B$, brown banded zinc clay, sauconite, showing characteristic conchoidal fracture (from Loughlin, 1918, pl. 6C). 
arch and Aspen districts, and by Behre (1953, p. 92; 1932) in the "South workings" of the Continental Chief mine, which is on the crest of the Mosquito Range east of Leadville, and in the Weston Pass district farther south in the Mosquito Range.

\section{HYDROZINCTTE}

This chalky white basic zine carbonate is commonly in the form of eggshell-like platy masses that replace and coat smithsonite. The mineral contains a maximum of about 74 percent zinc oxide.

Hydrozincite is a major constituent of the oxidized zinc deposits at Rifle, Colo., at the small mines and prospects on the south side of the Yampa River along the south boundary of Dinosaur National Monument, and at the Sedalia mine near Salida. It is a fairly common mineral at Rico and possibly in the Horseshoe district. Elsewhere, however, it is either absent or very common in the oxidized zinc deposits.

\section{AURICHALCTTE}

Aurichalcite, the basic carbonate of zinc and copper, is a pale-green to sky-blue mineral that has a pearly or silky luster and is commonly in radiating clusters of small columnar, platy, or needlelike crystals. The metallic content ranges from 40 to 47.5 percent zinc and from 15 to 22 percent copper.

In most places the mineral is uncommon, but it has been produced commercially from one or two mines at Leadville and is common at the Mantle mine in Dinosaur National Monument, at many of the smaller replacement deposits on Mount Sherman in the Alma district, at the Sedalia mine near Salida, and locally at the Doctor mine on Spring Creek west of Taylor Park. Eckel (1961, p. 62) states that aurichalcite is reported from the Jones mine in the Central City district.

\section{SAUCONITE}

White, brown, and black zinc clays (fig. $3 B$ ) are locally abundant at Leadville and at the Continental Chief mine on Mount Sherman in the Mosquito Range (Behre, 1953, p. 93). At these localities the clays are found in quantities large enough to constitute ore bodies. The purer zinc clays contain between 20 and 25 percent zinc and are the clay mineral sauconite. As far as is known, recovery of the zinc from sauconite is too difficult to yield a profit. The reader is referred to Loughlin (1918, p. 24-28, 47), Emmons, Irving, and Loughlin (1927, p. 160-162, 264-270), and Ross (1946, p. 411-424) for detailed descriptions of sauconite, its composition, and its origin. 


\section{OTHER SECONDARY ZINC MINERALS}

None of the other oxidized zinc minerals are abundant enough to constitute ore. The zinc sulfate, goslarite, is common in small quantities in the zone of oxidation of zinc sulfide deposits; but, because it is water soluble, it rarely accumulates in minable quantities. Creede is an example of a district where goslarite is in sufficient quantity to be an ore mineral. Serpierite, a rare copper-zinc sulfate, is reported from near Salida, Colo. (Mary Mrose, U.S. Geol. Survey; oral communication, 1958), but the exact locality is not known. A creamywhite or brown very fine grained zinc sulfide determined by $\mathrm{X}$-ray analysis as sphalerite is a common but minor constituent of the oxidized zinc ore bodies at Aspen and Lenado. The sphalerite was probably deposited as a supergene sulfide around nuclei of galena in the acid solutions that were formed during oxidation of the primary lead and zinc sulfide ores. Zincian aragonite, nicholsonite, was described by Butler (1913, p. 8-9) at Leadville, but most of the aragonite at Leadville contains little zinc. It is in white acicular crystals or radiating aggregates that resemble hemimorphite, but it lacks the sheaflike bladed form of that mineral. Eckel (1961, p. 57) describes an occurrence of nicholsonite in the Carbonate district north of Glenwood Springs. The zinc-lead vanadate, descloizite, was reported by Emmons and Irving $(1907$, p. 33) in the downtown part of the Leadville district as uncommon thin reddish-brown crystallized crusts. Descloizite becomes much more abundant in the States to the west, south, and southwest.

Rosasite (?), a zinc-rich analog of malachite that is not fully established as a mineral species, may be a minor constituent of ore at the Sedalia mine. Here occurs dark-blue-green mammillary radial fibrous crusts that closely resemble rosasite(?) from the type locality in Sardinia. The rosasite (?) from the two localities has very similar X-ray patterns, and these patterns show the mineral to be isostructural with malachite (Mary Mrose, U.S. Geol. Survey, oral communication, 1959), but further studies are in progress to fully establish the mineral as a species. An associated fibrous mineral that closely resembles rosasite(?) but is bright blue has a distinctive X-ray pattern unlike that of any other known mineral.

\section{ASSOCIATED SECONDARY MINERALS}

Secondary minerals commonly found in oxidized zinc deposits in Colorado include the following:

\footnotetext{
Goethite $\left[\mathrm{HFeO}_{2}\right]$ and limonite [hydrous iron oxides]

Cerussite $\left[\mathrm{PbCO}_{3}\right]$ (possibly hypogene in places)

Jarosite $\left[\mathrm{KFe}_{3}\left(\mathrm{SO}_{4}\right)_{2}(\mathrm{OH})_{6}\right]$

Plumbojarosite $\left[\mathrm{PbFe}_{6}\left(\mathrm{SO}_{4}\right)_{4}(\mathrm{OH})_{12}\right]$
} 
Pyrolusite $\left[\mathrm{MnO}_{2}\right]$

Psilomelane [near $\mathrm{BaMnMn}_{8} \mathrm{O}_{16}(\mathrm{OH})_{4}$ ] or cryptomelane [near $\mathrm{K}_{2} \mathrm{Mn} \mathrm{Mn}_{7} \mathrm{O}_{16}$ ]

Calcite and travertine $\left[\mathrm{CaCO}_{3}\right]$

Opal $\left[\mathrm{SiO}_{2} \cdot n \mathrm{H}_{2} \mathrm{O}\right]$

Anglesite $\left[\mathrm{PbSO}_{4}\right]$

Cerargyrite [AgCl]

Argentite $\left[\mathrm{Ag}_{2} \mathrm{~S}\right]$

Wulfenite $\left[\mathrm{PbMoO}_{4}\right]$

Kaolinite $\left[\mathrm{Al}_{2} \mathrm{Si}_{2} \mathrm{O}_{5}(\mathrm{OH})_{4}\right]$

Malachite $\left[\mathrm{Cu}_{2}(\mathrm{OH})_{2}\left(\mathrm{CO}_{3}\right)\right]$

Azurite $\left[\mathrm{Cu}_{3}(\mathrm{OH})_{2}\left(\mathrm{CO}_{3}\right)_{2}\right]$

Pyromorphite $\left[\mathrm{Pb}_{5}\left(\mathrm{PO}_{4}, \mathrm{AsO}_{4}\right)_{3} \mathrm{Cl}\right]$

Mimetite $\left[\mathrm{Pb}_{5}\left(\mathrm{AsO}_{4}, \mathrm{PO}_{4}\right)_{3} \mathrm{Cl}\right]$

Gypsum [CaSO $4 \cdot 2 \mathrm{H}_{2} \mathrm{O}$ ]

Gold [Au]

Silver $[\mathrm{Ag}]$

Tenorite [CuO] and copper pitch [a massive form of tenorite]

Chrysocolla [CuSiO $\left.3 \cdot 2 \mathrm{H}_{2} \mathrm{O}\right]$

Cuprite $\left[\mathrm{Cu}_{2} \mathrm{O}\right]$

Minium $\left[\mathrm{Pb}_{3} \mathrm{O}_{4}\right]$

Chalcocite $\left[\mathrm{Cu}_{2} \mathrm{~S}\right]$

Hematite $\left[\mathrm{Fe}_{2} \mathrm{O}_{3}\right]$

Phosgenite $\left[\mathrm{Pb}_{2}\left(\mathrm{CO}_{3}\right) \mathrm{Cl}_{2}\right]$ (possibly hypogene in places)

Ferrimolybdite $\left.\left[\mathrm{Fe}_{2}\left(\mathrm{MoO}_{4}\right)_{3} \cdot 8 \mathrm{H}_{2}\right)\right]$

Chalcanthite [CuSO${ }_{4} \cdot 5 \mathrm{H}_{2} \mathrm{O}$ ]

Aragonite $\left[\mathrm{CaCO}_{3}\right]$

Bismutite $\left[(\mathrm{BiO})_{2}\left(\mathrm{CO}_{3}\right)\right]$

The most abundant minerals associated with the oxidized zinc ores in Colorado are goethite and limonite, quartz, dolomite, calcite, siderite and manganosiderite, cerussite, galena, jarosite and plumbojarosite, barite, psilomelane and pyrolusite, malachite, and cerargyrite. The rest of the more common associated minerals, both primary gangue minerals and secondary oxidation products, have been listed previously (p. C9).

Limonite and goethite occur as yellow, brown, and dark-brown masses that coat and replace weathered smithsonite. In some localities such as the Doctor mine in the Spring Creek district, the ironoxide minerals are probably mainly oxidation products of pyrite, which was an abundant constituent of the primary ores; elsewhere, where siderite and manganosiderite are abundant gangue minerals, at least some of the limonite is formed by the oxidation of these ironrich carbonates. Most of the manganese in the manganosiderite, in turn, is redeposited as pyrolusite, psilomelane, and cryptomelane. At many of the deposits, much soft brown and yellow material that resembles earthy limonite in general appearance is composed of minute granular hexagonal flakes of jarosite or plumbojarosite.

Calcite is found in many of the ores as bands of smithsonitelike travertine and as small transparent scalenohedral or rhombohedral 
crystals. At Leadville, acicular white crystals and radiating masses of aragonite are common secondary constituents of small veins and vugs. Chemical, X-ray, refractive-index, and other optical tests are needed to distinguish much of this calcium carbonate from smithsonite, although the greater specific gravity of the latter is commonly helpful.

Silica is a common gangue mineral, mostly in dense forms such as jasperoid, chalcedony, or opaline jasper. The silica replaces the more massive varieties of smithsonite where they have been further weathered and leached; partial replacements are even more common. Jasperoid and chalcedony are closely associated with hemimorphite in many places, the latter filling cavities in the quartz.

Galena is the only abundant sulfide in some oxidized zinc deposits, where it occurs as unoxidized remnants partly replaced and encased in oxidized lead minerals. However, it is only in deposits where the zinc ores oxidized virtually in place without much migration, as at Aspen. In such deposits, cerussite, anglesite, plumbojarosite, and, less commonly, wulfenite and pyromorphite are constituents of the ores. At the Doctor mine in the Spring Creek district, oxidation is so complete that nearly all the galena is altered to oxidized lead minerals, and a careful search yielded but a single grain of galena. In contrast, the oxidized lead minerals are rare or absent in most oxidized zinc deposits in which the zinc-bearing solutions migrated during oxidation and replaced the limestone and dolomite wall rocks.

Silver, probably in the form of cerargyrite, is a notable constitutent of the oxidized zinc ores in the Tincup district; some of these ores contain as much as 25 to 50 troy ounces of silver per ton.

Malachite, azurite, wulfenite, pyromorphite, and descloizite are much less common in the oxidized zinc deposits of Colorado than in the deposits in States to the west and south; and zinc arsenates, which occur in these other States, are not known in Colorado. In contrast, the usually uncommon minerals minium, bismutite, native silver, and chalcanthite were all locally abundant at Leadville in the rich oxidized ores mined prior to World War I.

\section{MODE OF OCCURRENCE OF OXIDIZED RINC DEPOSITS}

Most oxidized zinc deposits in Colorado are in areas where an abundance of limestone and dolomite wallrock is combined with welldeveloped open fracture systems and with a water table that was greatly lowered sometime during the more recent periods of geologic history to provide ideal conditions for oxidation of the primary ore deposits by carbonated, lateral-moving, and descending ground waters. In most places the deposits are not restricted to certain limestones but may occur in any of the carbonate rock units of pre-Pennsylvanian age. 
TABLe 2.-Generalized stratigraphic section of the Paleozoic sedimentary rocks in the Sawatch Range area

\begin{tabular}{|c|c|c|c|c|c|c|}
\hline \multicolumn{2}{|c|}{ System and series } & $\begin{array}{l}\text { Group and } \\
\text { formation }\end{array}$ & Member & \multicolumn{2}{|c|}{$\begin{array}{c}\text { Thickness } \\
\text { (feet) }\end{array}$} & Description \\
\hline \multicolumn{2}{|c|}{$\begin{array}{c}\text { Pennsylvanian and } \\
\text { Permian }\end{array}$} & \multirow{2}{*}{$\begin{array}{l}\text { Maroon } \\
\text { Formation } \\
\text { Onconformity } \\
\text { (in south) } \\
\text { Minturn } \\
\text { Formation }\end{array}$} & $\begin{array}{l}\text { Pony Spring } \\
\text { Siltstone } \\
\text { (Gould, 1935) } \\
\text { Chubb Silt- } \\
\text { stone (Gould, } \\
\text { 1935) } \\
\text { Coffman con- } \\
\text { glomerate } \\
\text { (Gould, 1935) }\end{array}$ & & $0-2,000$ & $\begin{array}{l}\text { Red beds; arkose, grit, } \\
\text { shale, conglomerate, sand- } \\
\text { stone, siltstone, argillite, } \\
\text { thin lenses. Not differ- } \\
\text { entiated, if present near } \\
\text { Monarch; absent at } \\
\text { Leadville }\end{array}$ \\
\hline \multicolumn{2}{|c|}{$\begin{array}{c}\text { Pennsylvanian and } \\
\text { Permian(?) }\end{array}$} & & $\begin{array}{l}\text { Mostly undiffer- } \\
\text { entiated; } \\
\text { lower part } \\
\text { divided into } \\
\text { members at } \\
\text { Pando }\end{array}$ & \multicolumn{2}{|c|}{$2,000-6,000$} & $\begin{array}{l}\text { Gray sandstone, gray and } \\
\text { black shale, and thin } \\
\text { limestones and dolomites } \\
\text { near base; called Weber(?) } \\
\text { by Behre (1953) at Lead- } \\
\text { ville }\end{array}$ \\
\hline \multicolumn{2}{|c|}{ Pennsylvanian } & \multirow{5}{*}{$\begin{array}{c}\text { (locally) } \\
\text { Leadville Lime- } \\
\text { stone } \\
\text { (not differ- } \\
\text { entiated in } \\
\text { south) } \\
\text { - Unconformity - } \\
\text { Chaffee Forma- } \\
\text { tion }\end{array}$} & Undifferentiated & & $25-2,000$ & $\begin{array}{l}\text { Dark carbonaceous argillite } \\
\text { and thin-bedded lime- } \\
\text { stones, and a few beds } \\
\text { of quartzite. Not recog- } \\
\text { nized at Lead ville (Behre, } \\
\text { 1953). Called Weber(?) } \\
\text { at Aspen (Vanderwilt, } \\
\text { 1935) }\end{array}$ \\
\hline \multirow{2}{*}{\multicolumn{2}{|c|}{ Mississippian }} & & $\begin{array}{l}\text { Unnamed lime- } \\
\text { stone and } \\
\text { dolomite } \\
\text { member }\end{array}$ & $0-350$ & (in north) & $\begin{array}{l}\text { Upper part of Blue Lime- } \\
\text { stone of earlier reports. } \\
\text { Massive gray erystalline } \\
\text { cherty dolomite and } \\
\text { limestone; upper part } \\
\text { limestone Nearly all } \\
\text { dolomite between Lead- } \\
\text { ville and Minturn, Colo. }\end{array}$ \\
\hline & & & $\begin{array}{c}\text { Gilman Sand- } \\
\text { stone }\end{array}$ & & (in north) & $\begin{array}{l}\text { Dolomitic sandstone, chert, } \\
\text { and dolomitic breccia, } \\
\text { conglomerate }\end{array}$ \\
\hline \multirow[t]{2}{*}{ Devonian } & \multirow[t]{2}{*}{ Upper } & & Dyer Member & & $15-115$ & $\begin{array}{l}\text { Lower part of Blue Lime- } \\
\text { stone of earlier reports. } \\
\text { Dyer is mostly gray dolo- } \\
\text { mite and limestone. } \\
\text { Parting is white quartz- }\end{array}$ \\
\hline & & & Parting Quartz- & & $27-65$ & $\begin{array}{l}\text { mitic limestone inter- } \\
\text { bedded with sandstone } \\
\text { and shale in south }\end{array}$ \\
\hline \multirow{3}{*}{ Ordovician } & $\begin{array}{l}\text { Middle } \\
\text { and } \\
\text { Upper }\end{array}$ & \multirow{4}{*}{$\begin{array}{c}\begin{array}{c}\text { Fremont Lime- } \\
\text { stone } \\
\text { - Unconformity - } \\
\text { Harding quartz- } \\
\text { ite }\end{array} \\
\text { - Unconformity - } \\
\begin{array}{c}\text { Manitou Forma- } \\
\text { tion }\end{array} \\
\text { - Unconformity - } \\
\text { Peerless Forma- } \\
\text { tion }\end{array}$} & Undifferentiated & & $0-135$ & $\begin{array}{l}\text { Bluish-gray mottled mas- } \\
\text { sive limestone; crystal- } \\
\text { line dolomite, present } \\
\text { locally, especially in } \\
\text { south }\end{array}$ \\
\hline & Middle & & Undifferentiated & & $0-38$ & $\begin{array}{l}\text { Bluish-gray, tan, or white } \\
\text { quartzite or sandstone. } \\
\text { Absent at Lead ville and } \\
\text { Aspen }\end{array}$ \\
\hline & Lower & & Undifferentiated & & $0-250$ & $\begin{array}{l}\text { The White Limestone of } \\
\text { earlier reports. Not pres- } \\
\text { ent near Pando Light- } \\
\text { gray or gray dolomitic } \\
\text { limestone or dolomite }\end{array}$ \\
\hline \multirow{2}{*}{ Cambrian } & \multirow{2}{*}{ Upper } & & Undifferentiated & & $0-112$ & $\begin{array}{l}\text { Thin-bedded buff, green, } \\
\text { and reddish sandy dolo- } \\
\text { mite and sandstone. Not } \\
\text { present in south }\end{array}$ \\
\hline & & $\begin{array}{l}\text { Sawatch } \\
\text { Quartzite }\end{array}$ & Undifferentiated & & $100-185$ & $\begin{array}{l}\text { Fine-grained quartzite, and } \\
\text { sandstone; pink or purple } \\
\text { near base and top; thin } \\
\text { conglomerate near base }\end{array}$ \\
\hline \multicolumn{2}{|c|}{ Precambrian } & Undifferentiated & & & & $\begin{array}{l}\text { Granite, gneiss, schist, and } \\
\text { local marble lenses }\end{array}$ \\
\hline
\end{tabular}




\section{DISTRIBUTION IN RESPECT TO KINDS OF COUNTRY ROCK}

Table 2 is a generalized stratigraphic section of the Paleozoic rocks that include the oval belt of limestones which surround the Sawatch Range. In parts of the area, such as at Leadville (Behre, 1953, p. 2542) and Aspen (Vanderwilt, 1935, p. 224-230, fig. 1), the Pennsylvanian and (or) Permian rocks have not been differentiated but are listed in part under the name Weber(?) Formation from rocks of equivalent age in Utah. The section of pre-Pennsylvanian rocks at Aspen is different from the section elsewhere mainly in the absence of Fremont Limestone and Harding Quartzite of Ordovician age and in a marked local thinning of the Leadville Limestone owing to an unconformity at the base of the overlying Pennsylvanian rocks.

The great deposits of oxidized zine ores at the Leadville, Monarch, Spring Creek, and Horseshoe districts are all within the Manitou Formation, the Fremont and Leadville Limestones or in the Dyer Member of the Chaffee Formation. At Aspen, all ore production has been from the contact of the Leadville Limestone with the overlying shaly rocks of Pennsylvanian age or along the contact between limestone beds and the dolomite beds within the Leadville Limestone.

Elsewhere in western Colorado, except at Rico, Creede, and the Sedalia mine, the limestones and dolomites of Ordovician, Devonian, and Mississippian age--equivalents of the limestone rocks of the main oval belt-are principal host rocks for the oxidized zinc deposits of commercial size.

The oxidized zinc ores at Rico occur at the margins of oxidized replacement and blanket deposits in thin limestone bands in the middle part of the Hermosa Formation of Pennsylvanian age. A noteworthy feature of the deposits, both primary and secondary, is their restriction to the middle part of this formation; there, the deposits show a marked preference for replacing the limestone beds that are interbedded with shales, sandstones, and conglomerates. Elsewhere in Colorado, no oxidized zinc deposits of commercial size are known in the thin limestone units of the clastic formations of Pennsylvanian and (or) Permian age.

Oxidized zinc ores have been produced from Precambrian rocks at the Sedalia mine (pl. 1, no. 101). The host rocks are dark-gray schists including actinolite, quartz-biotite-sillimanite-garnet, and chloritic varieties.

\section{TYPES OF DEPOSITS AND THEIR RETATIONS TO OTHER ORES}

Some distinct types of oxidized zinc deposits occur in Colorado, some of which have been described by Loughlin (1918, p. 36-47, 54-61, 
69-85). The types can be classified by composition, genesis, position, shape, degree of oxidation, and composition as follows:

I. Deposits probably formed by hypogene solutions: epithermal(?) veins and massive sulfide deposits.

Examples:

F. M. D. mine, Evergreen district

Bon Ton mine, Monarch district

II. Deposits formed by supergene solutions.

A. Deposits formed by direct replacement of primary sulfides:

1. Oxidized veins and breccias:

a. Early progressive oxidation stage:

Examples:

New York mine, Monarch district

Carbonate mines, Carbonate district

Amethyst-Happy Thought mine, Creede district

b. Late progressive oxidation stage

Example: Mantle mine, Massadona-Youghall district

2. Oxidized massive bodies:

a. Early progressive oxidation stage:

Examples:

Smuggler and Molly Gibson mines, Aspen district

Doctor mine, Spring Creek district

Tincup district

b. Late progressive oxidation stage:

Example: Sedalia mine, Turret district

3. Oxidized disseminated deposits

Example: Sunshine Lode mine, Rifle Creek district

B. Deposits formed by replacement of the wallrock after migration of zinc (early progressive oxidation stage):

1. Blanket and pocket ore bodies

Examples:

Carbonate Hill mines (Maid of Erin, Brookland,

Tucson, Wolftone), Leadville district

Madonna mine, Monarch district

2. Replacement shells around pipes or mantos

Example: Hilltop mine, Horseshoe district

3. Replacement bodies in vein walls and secondary veins along fissures

Examples:

Belgian mine, Leadville district

Tucson and Oro LaPlata mines, Leadville district

\section{DEPOSITS PROBARLY FORMED BY HYPOGENE SOLUTIONS}

Genetically the most unusual deposit of zinc-bearing carbonate in Colorado, though it is of no commercial value, is in the F.M.D. mine (pl. 1, no. 13) in the Malachite or Pipe district near Evergreen, where thin vuggy veins of dark-brown fine-grained zincian siderite fill fissures and cement rock and sulfide breccias in veinlike massive sulfide 
ore bodies (Lindgren, 1908, p. 168-169). The massive sulfide bodies are in shear zones in hornblende-biotite gneiss that is cut by pegmatite and altered mafic dikes. The primary minerals of the massive sulfide ore bodies, in their relative order of abundance, are pyrrhotite, magnetite, chalcopyrite, iron-rich black sphalerite, pyrite, and molybdenite. Fractures in both the sulfide ore and the gneiss wallrock are filled with veins of zincian siderite, small cubes of lustrous pyrite, a little black sphalerite, calcite, and stilbite. According to Lindgren (1908, p. 169), the siderite (analyzed by Dr. E. C. Sullivan) contains 11.6 percent zinc oxide (9.3 percent zinc) and is allied to monheimite. A partia] analysis of a sample of the zincian siderite, selected from the dump and containing small quantities of impurities including pyrite and rock gouge, was made with the following results:

\section{Partial analysis of selected dump sample of zincian siderite}

[Analyst, Deason and Nichols, Salt Lake City, 1955, except antimony and selenium, which were determined by H. E. Crowe, U.S. Geol. Survey, 1955]

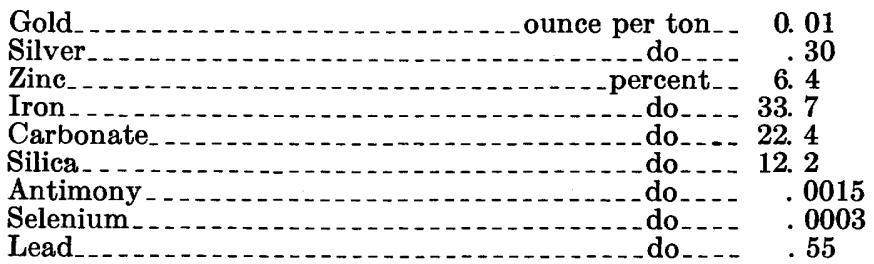

Zincian siderites are rare, and this variety falls in a reported gap in the series between smithsonite and siderite (Palache and others, 1957, p. 178-179). Further mineralogic work and a complete chemical analysis of the pure mineral should be done to fully establish its composition.

Gahnite, zinc spinel, is a high-temperature vein mineral occurring with sphalerite and pyrite in the vein, and it also occurs replacing the nearby garnetiferous gneiss of Precambrian age at the Bon Ton mine southeast of Monarch. Gahnite is common in the massive sulfide copper-zinc ores at the Cotopaxi mine near Cotopaxi and at the Sedalia mine near Salida.

Lead carbonate deposits containing a little zinc carbonate, which may have been deposited as primary minerals directly from hydrothermal carbonated solutions, are known at Ilse in the Wet Mountains (Hunter, 1914, p. 25-37; Emmons, 1896, p. 405-472) and at the Lark mine (pl. 1, no. 111) in the San Juan Mountains (Wilbur Burbank, oral communication, 1954). The amount of zinc in these lead deposiits is apparently small, ranging between 0.1 and 3 percent in several rich ore samples collected from outcrops, but parts of the Lark deposit are reported to be rich in zinc carbonate. 
All the cerussite seen in the mine at Ilse apparently was deposited directly from solution in coarsely crystalline white masses and thin white veinlets that fill fractures and cement breccia in a wide major fault zone in gneisses of Precambrian age. The cerussite and the less common phosgenite closely resemble vein quartz. No remnants of partly oxidized galena or cavities of leached sulfides were noted in the deposit. Limonite also is uncommon, being restricted to brown stains throughout the fault zone. Calcite and a little smithsonite are the only other minerals present.

The lead carbonate pipes at the Lark mine cut vertically through silicic volcanic rocks of Tertiary age and are not known to contain sulfides. The cerussite is massive, earthy, or thinly banded, and most of it is white, pale gray or buff. However, a very few grains having concentrically banded dark-gray centers were seen, and these grains could be cerussite which recently replaced galena and still retains the dark color. A network of lead carbonate pipes is known to extend vertically for 1,000 feet; these pipes surround a central leadzinc-silver sulfide pipe that crops out at the surface (Wilbur Burbank, oral communication, 1954).

\section{DEPOSITS FORMED BY SUPERGENE SOLUTTONS}

All known oxidized zinc deposits of commercial value have been formed by supergene solutions that have oxidized zinc sulfide deposits. Deposits formed by direct replacement of primary ore bodies are common in Colorado, but they have produced a much smaller volume of ore than have the deposits formed by migration of the zinc and redeposition in pockets, blankets, and sheaths in the wallrock. Deposits of the latter type have been described by Loughlin (1918), but deposits formed by direct replacement of primary ores have been little described and therefore receive the emphasis in the following descriptions. Similar deposits in Utah have been described in some detail by the author (Heyl, 1963).

\section{DIRECT REPLACEMENT OF PRIMARY GULFIDES}

Zinc-rich oxidized deposits that were formed by direct replacement of primary sulfide ores are much more abundant than is commonly realized. Many of the deposits were mined years ago for their silver and lead content; the zinc was not recovered because it was of little value. Direct-replacement deposits in (a) veins and breccias, (b) massive bodies that originally replaced wallrock, and (c) disseminations may be in either an early or a late stage of progressive oxidation and leaching. In the early stage of oxidation, all three types commonly contain incompletely replaced grains of galena and, less commonly, sphalerite. In Colorado, deposits in the early stage are most 
abundant, and only a few in the late stage are known. In the more arid parts of the West such as Nevada and southern California, latestage deposits are more abundant and show features. of deep and intense oxidation that are very uncommon in the Colorado deposits.

Smithsonite that directly replaced sphalerite is commonly in porous brown masses and in coarse cellular, spongy boxworks with a rudely triangular pattern that is the result of partial selective replacement of the sphalerite along cleavage planes. Crystallized gray and white crusts of smithsonite are uncommon except locally within the boxwork vugs. Hemimorphite is abundant in deposits with siliceous gangue and (or) wallrock in the form of drusy crystal crusts, masses, or discrete crystals and clusters in vugs. Boxworks of limonite are common, and platy and massive limonite much less so. Hydrozincite, chalcophanite, sauconite, and willemite are less common.

Deposits in the late stage of oxidation are characterized by an abundance of hydrozincite, aurichalcite, and willemite and by the rarity of smithsonite and of lead, copper, and zinc sulfides, especially galena. In the final stages, approaching a gossan, only a little zinc remains as hemimorphite or willemite; and supergene calcite, lamellar limonite, and jasperoid are very abundant.

\section{OXIDIZED VEINS AND BRECCIAS}

The Iron (or Irony) vein of the New York Tunnel (pl. 3; Ames, 1946, p. 4, figs. 2, 3) in the Garfield part of the Monarch district is an excellent example of a direct-replacement fissure-vein deposit in the early stage of oxidation. Here, a vein 180 feet long and, on the average, 6 feet wide of fine-grained smithsonite, hemimorphite, and gouge dips steeply westward in limestone. The ore is fairly rich and is stained with iron oxides; it contains about 20 to 25 percent zinc, 1 to 2 ounces of silver per ton, and nearly 1 percent lead. Partly replaced sphalerite remains in the vein at floor level, particularly at the northeast end. A crosscutting vein contains oxidized silver minerals and a little smithsonite. Similar veins and breccias in limestone in the Carbonate district north of Glenwood Springs are described in a later section of this report (p. C52).

Oxidized zinc-bearing lead-silver ore occurs in noncarbonate rocks in parts of the Amethyst-Happy Thought vein at Creede (Emmons and Larsen, 1913). Silver-lead fissure veins with quartz and barite gangue cut rhyolites and other related volcanic rocks and are oxidized to depths of 500-800 feet below the surface. The primary sulfide ore, which is rich in sphalerite, loses most of its zinc during oxidation. Some zinc remains as smithsonite, hemimorphite, and goslarite, so that the oxidized lead-silver ores contain 1 to 3 percent zinc. Locally the zinc minerals are more concentrated: about 5 percent of 
the ore in the oxidized zone contains 3 to 10 percent zinc, and some contains as much as 12 percent. A partial analysis of low-grade zincbearing material containing anglesite, goslarite, and smithsonite(?) is given below :

\section{Grab sample from oxidized vein, Creede}

[Analyst, Deason and Nichols, Salt Lake City, 1955, except for antimony and selenium, which were determined by H. E. Crowe, U.S. Geol. Survey Geochemical Exploration Laboratory, 1955]

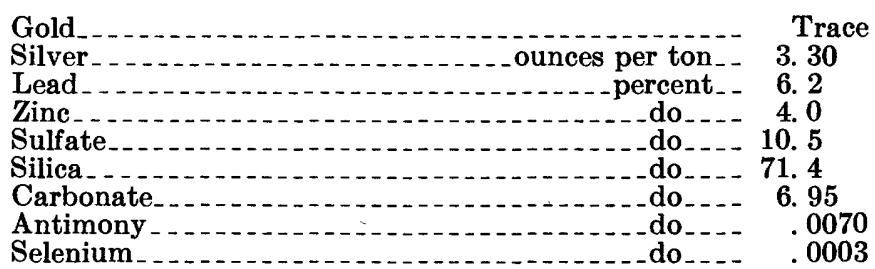

Similar concentrations of oxidized zinc minerals in silver-lead veins in noncarbonate rocks are known in the Spar district southwest of Creede, in the Breckenridge district, and in the Silver Cliff district; but such deposits are not common in Colorado. More commonly, all or nearly all the zinc is leached during oxidation, and no secondary zinc minerals are formed.

Oxidized zinc veins in limestone that are in the late stage of progressive oxidation are along the south boundary of the Colorado part of Dinosaur National Monument. The largest of several small deposits is that of the Mantle mine, which is in a weak shear zone of nearly vertical fractures that contain veins and mineralized breccias of oxidized zinc and copper ore. The veined shear zone is exposed for about 100 feet vertically in the south side of Yampa Canyon, extending across the contact between quartzite and shale of Cambrian age below and limestone of Mississippian age above (Untermann and Untermann, 1954, p. 10, figs. 8, 9). No sulfides remain, but the secondary copper minerals (mostly in the parts of the veins cutting quartzite and shale below the contact) and the zinc minerals (mostly in the parts of the veins cutting limestone) appear to have directly replaced the original sulfide minerals.

The secondary zinc minerals are hydrozincite and pale blue-green radiating hemimorphite; no smithsonite was seen. They are in banded masses, open-textured cavity fillings, and delicate boxworks of zine minerals and gossans, some of which retain the outlines of the leached sulfide grains. The gangue minerals are cleavage masses of calcite and travertine, quartz and jasperoid in veinlets, and finegrained dolomite that has replaced the limestone wallrock and is stained with hematite. Cerussite and a little lead arsenate and yellow lead-antimony ochers are the only lead minerals present.

An analysis of oxidized zinc ore from the upper adit of the Mant' mine is given below : 
412-foot channel sample across the main vein in the floor of upper adit, Mantle mine Massadona-Younghall district

[Analyst, Deason and Nichols, Salt Lake City, 1955]

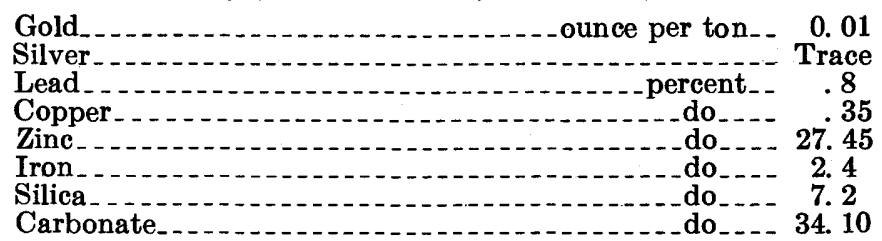

The sample shows that the ores are unusual among those that directly replace original sulfides because they are lean in iron, lead, and silver. The near absence of silver suggests that the primary ores were deposited by rather low temperature epithermal solutions far from their source. The presence of small quantities of gold and copper, however, is unusual in such ores.

\section{OXIDIZED MASSIVE BODIES}

Some of the largest oxidized zinc ore bodies known in Colorado are those that have directly replaced massive sulfide ores and have retained their form. Several examples are in the Aspen, Lenado, and Spring Creek districts. The Aspen and nearby Lenado districts are best known for their large and rich silver-lead sulfide bodies (Spurr, 1898) and their large but low-grade lead-zinc sulfide bodies. The upper parts of several of the largest silver-lead ore bodies are leached to silver-bearing oxidized zinc-lead ores (fig. 4) that have directly replaced the sulfides. These massive podlike ore bodies are commonly along the brecciated contacts between massive dolomite and limestone units of the Leadville Limestone or between the Leadville Limestone and overlying Belden Shale. They are several hundred feet long and lie at the intersections of cross faults with bedding-plane faults (Spurr, 1898, p. 229-231) or with unfaulted bedding planes (Vanderwilt, 1935, p. 235-241). They are zoned (fig. 4) : the upper zones are rich in zinc and manganese and contain some lead and a little silver; the central zones are lead ores rich in silver; and the lower zones are rich silver ores consisting of barite and dendritic veinlets of polybasite and native silver. The wallrock within the ore bodies has been nearly completely replaced by the primary sulfides, manganese and ferroan dolomite, carbonates, and barite to form mineralized bodies of many thousands of tons.

Within the upper zinc-rich zones of the silver-lead ore bodies, nearly all the sphalerite has been replaced by dirty brown iron-rich smithsonite (monheimite) and hemimorphite, and some of the galena by anglesite and cerussite. Zinc carbonate is more abundant than zinc silicate. That the ores are rich in both zinc and lead and contain recoverable quantities of silver is shown in table 3 . 


\section{PART 3. COLORADO}

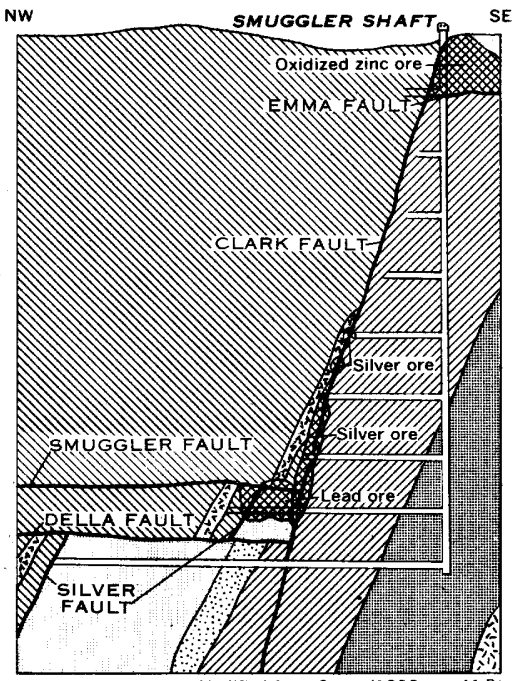

Modified from Spurr (1898, pl. 41D) i 300 FEET

EXPLANATION

SEDIMENTARY AND METAMORPHIC ROCKS

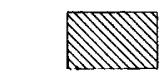

Argillaceous limestone and black shale of Pennsylvanian age

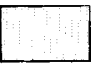

Massive blue dolomite and limestone of Devonian and Mississippian ages, undivided

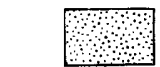

Dolomite, quartzite gray and red shale of Silurian age

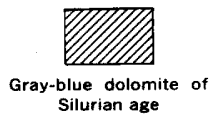

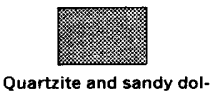
omite of Cambrian age

\section{1ำ,} 准得,

Granitic rocks and gneiss of Precambrian age

INTRUSIVE ROCKS

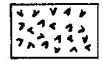

Quartz porphyry

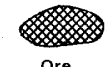

Ore

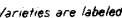

Mine workings

A

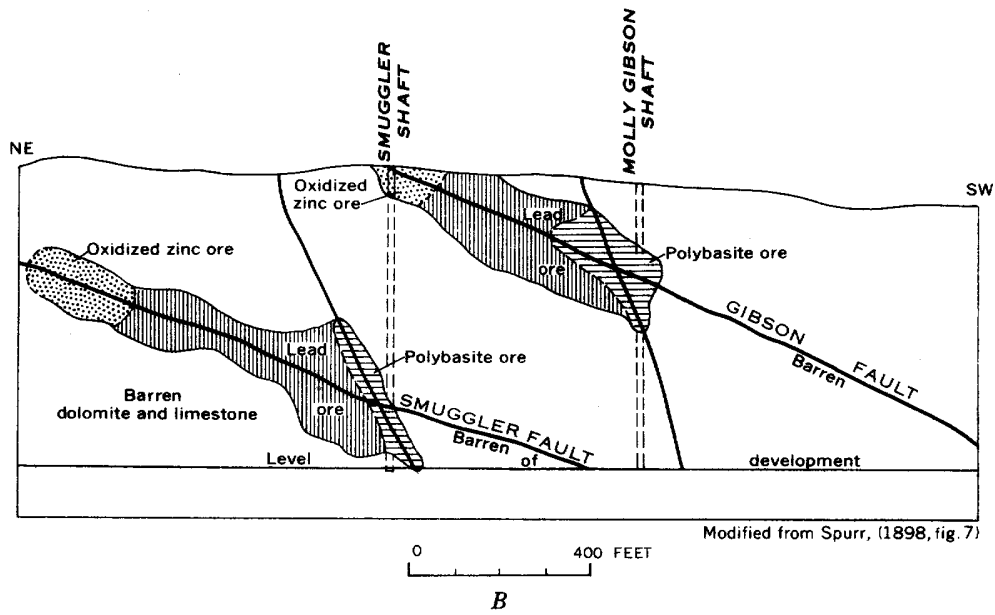

F1G0Re 4.-Diagrams of Smuggler and Molly Gibson ore bodies at Aspen, showing bodies of oxidized zinc ore. $A$, Diagrammatic vertical section through the Smuggler shaft; $B$, diagrammatic projection along the plane of the Clark fault. 
TABLE 3.-Analyses of oxidized zinc-lead ores, Aspen, Colo.

[Published with permission of the owners. nd, not determined]

\begin{tabular}{|c|c|c|c|c|}
\hline & 1 & 2 & 3 & 4 \\
\hline Gold & None & nd & nd & nd \\
\hline Silver & 1.40 & 12.7 & 3. 6 & 4. 2 \\
\hline Lead & 6.8 & 10.7 & 13. 9 & 15. 3 \\
\hline Zinc & 16. 1 & 21.8 & 37. 4 & 26. 8 \\
\hline Calcium oxide & nd & 7. 2 & 4. 8 & 6. 5 \\
\hline Silica & 9.6 & 11. 1 & 6. 1 & 7. 8 \\
\hline Iron & 7.2 & 3. 1 & 1. 9 & 3.2 \\
\hline Manganese & 11.9 & nd & nd & nd \\
\hline Arsenic & .07 & nd & nd & nd \\
\hline Antimony & .03 & nd & nd & nd \\
\hline Sulfur & nd & 1.2 & 14.0 & 2. 7 \\
\hline Barium sulfate & 5. 4 & 22.9 & Trace & nd \\
\hline Carbonate & 33.6 & nd & & nd \\
\hline
\end{tabular}

1. Random grab sample from shaft opencut, Smuggler mine, Aspen; analyst, Deason and Nichols, Salt Lake City, 1954.

2. A verage of 11 shipments of ore (208 tons) from Smuggler mine opencut, Aspen, 1911-13: analyst not known, smelter returns.

3. Average of 20 shipments of ore (625 tons) from Aspen Contact mine, at Lenado north of Aspen, 1920: analyst not known, smelter returns.

4. Average of 2 shipments of ore (24.6 tons) from Great Western mine, Aspen, 1916; analyst not known smelter returns.

Although the ores are dark in color, they are fairly lean in iron; they contain some manganese. Sulfur is present in unoxidized fragments of galena, and barium sulfate is abundant in those ores richest in silver.

One of the largest oxidized zinc-lead ore bodies in Colorado is opened by the Doctor mine (pl. 4) in the Spring Creek district north of Gunnison. The ore body is crescent shaped in plan and lies within a northward-trending zone of probable explosion breccia that cuts vertically across what is probably Leadville Limestone, much of which has been replaced and cemented by jasperoid and oxidized zinc, lead, and copper minerals. The probable Leadville Limestone is in a small faulted block of limestones and dolomites of Devonian and Mississippian age that trend northwest and dip northeast. The block has been uplifted by a fault at its southwest margin.

The mineralized part of the breccia zone is at least 1,100 feet long and 300 feet wide and is known to extend to depths of from 150 to 200 feet (Frank Hoheizel, operator of the Doctor mine from 1914 to 1918, oral communication, 1954). It is shaped somewhat like a funnel; it has an elongate oval section that constricts at depth from all sides. The richest ore is in a zone as much as 200 feet wide that also constricts with depth within the outer lean mineralized breccia (pl. 4). The dolomite dips eastward and is underlain by quartzite, against which the ore body is reported to end at a depth of from 10 to 50 feet beneath the old workings. The ore body may be the large remaining root of a formerly larger body, much of which has been eroded away. 
Most of the present oxidized ore body has directly replaced primary lead, zinc, and, locally, copper sulfides that were deposited in the breccia. Of these primary sulfides, only a very little galena remains, but cubic cavities formerly filled with galena and now partly filled with cerussite or anglesite were observed. Much of the remaining ore body is a fine-grained mixture of smithsonite, hemimorphite, cerussite, and anglesite that contains 10 to 20 percent zinc, several percent lead, and traces to 9 ounces of silver per ton. Other main supergene minerals are jarosite, plumbojarosite, limonite, azurite, malachite, and, locally, aurichalcite. The main gangue minerals are quartz (jasperoid variety), calcite, and dolomite.

Huge kidney-shaped concretionary masses of nearly pure brown smithsonite occur in places within the ore body. Such masses contributed a large part of the high-grade oxidized zinc ore shipped; most of which averaged 35 percent zinc and was nearly free of lead. The masses were undoubtedly formed during oxidation and by transportation of some of the zinc and redeposition as zinc carbonate in locally favorable areas within the mineralized zone. The loci for deposition of the concretionary masses may have been large blocks of unsilicified dolomite within the breccia, inasmuch as dolomite is especially favorable to replacement by smithsonite. Two such dolomite blocksstill unreplaced-in the southeastern part of the breccia zone are shown on plate 4.

Oxidized zinc ores rich in lead, gold, and silver have replaced sulfide deposits in the Tincup district (pl. 3) on the slope of the Sawatch Range in Gunnison County. "The replacement deposits are chiefly in limestone and dolomite of the Manitou, Chaffee, and Leadville formations $* * *$

*

Bedded replacement deposits [replacement deposits that follow bedding] are especially important economically in the Tincup district; ore deposits in the Gold Cup [Republic], Silver Cup, Tincup, Robert E. Lee, Drew, and El Capitan * * *" mines. (Dings and Robinson, 1957, p. 44-45), and in the accessible part of the Napoleon mine (pl. 3), have a roughly tabular form and " $* * *$ commonly plunge northeast down the gentle to moderate dip of the beds. Most of the ore in the district lies along the contact of a gray limestone and overlying dolomite in the Leadville formation about 150 feet stratigraphically below the top, although some ore bodies occur at stratigraphically lower positions ***" (Dings and Robinson, 1957, p. 45, pl. 4). At the mouth of the Napoleon mine, ore and white dolomite cement blue dolomite breccia. The largest ore body found to date is that of the Gold Cup Republic mine (pl. 3, no. 61), where a fairly continuous body of ore 
extends along the strike of the strata for about 1,000 feet and down the dip of the beds for about 800 feet.

The main minerals of the unoxidized ores are galena, sphalerite, chalcopyrite, pyrite, and tetrahedrite; quartz and white dolomite are the main gangue minerals. Such ores remain in the deeper parts of some of the mines, but most of the ore was oxidized to silver-bearing cerussite, hemimorphite, anglesite, and smithsonite, locally accompanied by cerargyrite, argentite, malachite, azurite, gold, chrysacolla, hydrozincite, manganiferous calcite, and porous limonite, limonitic quartz or jaspery limonite. The gray and white simthsonite is in coarse cellular and mamillary masses; the hemimorphite, in crusts of colorless crystals; the hydrozincite, in white egg-shell-like coatings. Small residual masses of galena remain in much of the oxidized lead and zinc ore.

All the oxidized zinc-bearing ores in the Tincup district are rich in silver, some are rich in gold, and nearly all contain some lead. Analyses of such ores are shown in table 4.

TABLE 4.-Analyses of oxidized zinc-lead ores from the Tincup district

[Published with permission of the owner. Analyst, Deason and Nichols, Salt Lake City, 1955; nd, not determinedl

\begin{tabular}{|c|c|c|c|}
\hline & 1 & 2 & 3 \\
\hline 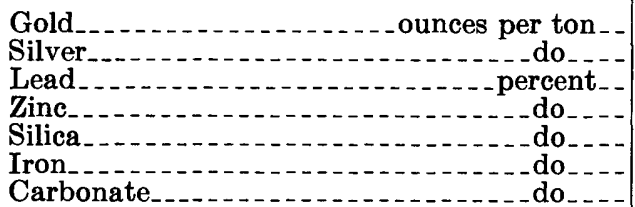 & $\begin{aligned} & 0 . 18 \\
& 50.10 \\
& 11.4 \\
& 39.7 \\
& 22.4 \\
& 3.4 \\
& 10.2\end{aligned}$ & $\begin{array}{l}\text { 0. } 34 \\
36.40 \\
12.2 \\
14.2 \\
36.9 \\
13.7 \\
11.1\end{array}$ & $\begin{array}{l}0.04 \\
28.50 \\
6.6 \\
37.9 \\
25.8 \\
\text { nd } \\
12.1\end{array}$ \\
\hline
\end{tabular}

1 Average of 2 determinations: 1.65 percent, 2.8 percent.

1. Selected richest zinc-lead ore, Creet mine.

2. Grab sample from ore bin of zinc-lead ore, Creet mine.

3. Representative composite sample of 4 ore piles, Napoleon mine.

All the samples are notably rich in silver-rich enough to make a good grade commercial silver and gold ore were it not for the abundance of the zinc. The samples from the Creet mine are notably rich in gold. Neither the gold nor the silver content shows any variation that corresponds with the lead content of the ores or, for that matter, with any of the other elements analyzed. The first and last samples are high-grade oxidized zinc as well as precious-metal ores. The author has described similar ores rich in precious metals from the American Fork, Park City, and Fish Springs districts of Utah (Heyl, 1963 , p. B16, B79-B80) and from several localities in Nevada and southern California (Heyl, 1963; Heyl and Bozion, 1962, p. A7-A8). At each locality the oxidized ores have replaced the primary sulfide ores with a minimum of migration of metal during oxidation. 
At the Sedalia mine north of Salida on the east side of the Arkansas River Valley, a large oxidized copper-zinc deposit has replaced noncarbonate rocks of Precambrian age. The deposit is completely oxidized at the surface and partly oxidized to about 300 feet below the present outcrop. The upper hundred feet has been leached to a gossan consisting mostly of limonite, quartz (jasperoid variety), malachite, and a little yellow earthy sulfate of lead and copper. ${ }^{1}$ Enough secondary zinc and copper from the oxidizing sulfides were concentrated in the second hundred feet to develop an ore body from which was mined much of the 60,000 to 75,000 tons of ore produced prior to 1908 (Lindgren, 1908, p. 161).

Hydrozincite, a mineral typical of the late progressive oxidation stage of zinc deposits, is fairly common in the oxidized zinc-copper ore, although some partly altered smithsonite still remains. Secondary willemite, a mineral characteristic of arid conditions, is present, but hemimorphite is the more abundant silicate of zinc in the ore observed by the writer. Two zinc-copper carbonates, aurichalcite and rosasite (?), are present in the ores, and the aurichalcite formed a commercially important minor constituent of the oxidized zinc ores that were shipped. Other minerals in the oxidized copper-zinc ore include limonite, cuprite, malachite, chalcocite, a little unaltered chalcopyrite, cerussite, and the earthy dull lemon-yellow basic lead-copper sulfate, and galena. A sample collected from the mine dump was analyzed to show the main components of this unusual sulfate-bearing material:

Selected sample oxidized zinc-copper material, Sedalia mine, Salida, Colo.

[Analyst: Deason and Nichols, Salt Lake City, 1956]

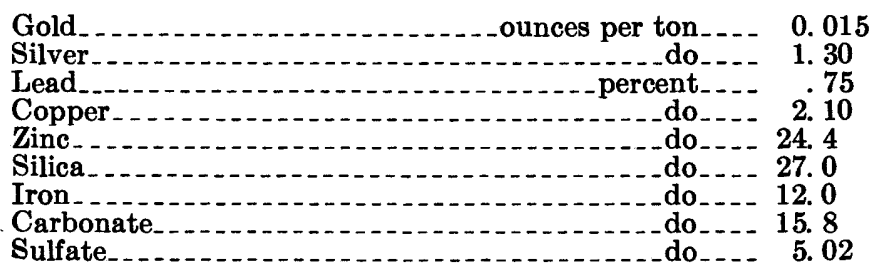

The minerals noted in this sample, in their general sequence of deposition, are quartz, willemite in small colorless etched crystals, limonite and reniform black manganese (and zinc?) oxide, partly decomposed brown smithsonite in scalenohedral crystals, white hydrozincite, limonite, sky-blue aurichalcite, colorless and pale bluegreen hemimorphite, malachite, rosasite(?), and an unidentified bright-blue fibrous mineral (see p. C16).

1 This incompletely described mineral is unnamed but is reported (Lindgren, 1908, p. 164) to have the formula $\mathrm{PbSO}_{4} \cdot \mathrm{CuSO}_{4} \cdot \mathrm{CuO}$. 
The ore body, according to Lindgren (1908, p. 163), is a thick unit of schist containing a mixture of quartz, actinolite, mica, staurolite, chlorite, garnet, sillimanite, and corundum and is richly impregnated with copper, lead, and zinc minerals. The ore body is conformable with the schists of Precambrian age; Lindgren states that it is a $6 * * *$ flat lens, 800 feet long and at most 150 feet thick, of amphibolitic rocks of varying types ***" that strike almost due east and dip $50^{\circ}-70^{\circ} \mathrm{S}$. The amphibolitic rocks are locally altered to talc and asbestos; they are intruded by many granite pegmatities, the largest of which is a dike 50 feet wide that crops out near the second main tunnel above the valley floor. This dike, which dips $70^{\circ} \mathrm{N}$., cuts off the main southward-dipping oxidized ore body; but at least one smaller body, mostly of sulfide ore, was found beneath the dike from the lowest (No. 3) tunnel. The main sulfides in the smaller body are pyrite, pyrrhotite, chalcopyrite, and ferroan sphalerite (marmatite) ; the other main primary minerals are magnetite, platy calcite, dark-green spinel (gahnite), quartz, tremolite, garnet, and hornblende. The ore contains some gold and silver.

\section{OXIDIZED DISSEMINATED DEPOSITS}

Oxidized disseminated zinc deposits are uncommon in Colorado. The Sunshine Lode mine (pl. 5) of the Rifle Creek district (pl. 1, no. 9), Garfield County, serves as an example. The deposit is in a fault zone that strikes $\mathrm{N} .10^{\circ} \mathrm{W}$. About 100 feet south of the mine is a major west-striking fault (Ogden Tweto, written communication, 1942) that displaces an anticline longitudinally on its south flank and brings Leadville Limestone of Mississippian age on the north against grit, shale, and minor limestone of the upper part of the Pennsylvanian Maroon Formation strata on the south. Massive limestone of the Leadville Formation dips gently northward because of local warping at the mine, and the limestone is cut by a narrow graben of sheared breccia as much as 60 feet wide that lies within a much wider and weaker shear zone several hundred feet wide. The graben strikes $\mathbf{N}$. $10^{\circ}-15^{\circ} \mathrm{W}$, and the bordering faults dip steeply eastward and are nearly parallel. Only Leadville Limestone crops out at the main level, but at the upper level, about 125 feet above, contorted red and green shales of Pennsylvanian age have been dropped down into the central block between walls of Leadville Limestone.

Black sphalerite and a little galena are the main sulfides at the Sunshine Lode mine; disseminated crystals and colloform crusts cement, replace, and partly fill the vuggy limestone breccia. Coarse-grained calcite and dolomite are the main gangue minerals, but a few coxcomb marcasite crystals are present; at the upper tunnel, a little white and 
black jasperoid cements the limestone breccia. The ore is lean in silver; the content ranges from 0.20 to 4.60 ounces per ton and apparently averages between 1 and 2 ounces per ton. Gypsum is the most unusual mineral in the sulfide ores, occurring as large selenite crystals in vugs. Probably it is a supergene mineral deposited in the vugs of the unoxidized ores from sulfate-rich solutions that percolated into them from the adjacent oxidizing ores.

The primary ores in this deposit have all the mineralogical characteristics of a low-temperature epithermal deposit and are markedly similar to the ores in several of the Mississippi Valley zinc districts (Ohle, 1959). The simple mineralogy, leanness in silver, colloform crusts, open vugs, coarse disseminated crystals, and abundant carbonate gangue minerals and very small quantities of other gangue minerals are all features typical of deposits in the Midwest.

At the Sunshine Lode the primary disseminated deposit has been fairly completely oxidized in place, and, locally, a very restricted migration of metals has occurred within the deposit. Smithsonite occurs as boxworks that replace the crusts and disseminated crystals of primary sphalerite. Locally the zinc has migrated to the adjacent calcite and replaced it, particularly in vuggy breccia. Much of the smithsonite that replaced calcite has been further altered to white claylike reniform crusts of hydrozincite. Gray cerussite locally surrounds the sparse partly replaced grains of galena. Some limonite stains and pseudomorphs after marcasite crystals are present, as well as a little yellow-brown flaky jarosite or plumbojarosite. Many crystal cavites from which sphalerite has been partly or completely leached are coated with black wadlike crusts of manganese oxides that are probably residues from the black, probably manganoan, sphalerite. No hemimorphite was observed, and no wallrock-replacement pockets of smithsonite or hydrozincite were seen. The abundance of hydrozincite and the fact that the sulfide ore in the fault zone is partly oxidized for at least 300 feet into the hill suggests that the deposit is approaching the late progressive stage of oxidation. More complete hydration of the smithsonite to hydrozincite, further leaching of the galena to cerussite and of the rest of the smithsonite to limonite and perhaps a little hemimorphite would probably complete the development of the late progressive stage in this deposit.

\section{REPLACEMENT OF WALLROCK AFTER MIGRAIION OF ZINC}

The most productive oxidized zinc ore bodies in Colorado were deposited by supergene solutions that migrated from the oxidizing sulfide ore bodies and replaced the limestone wallrocks with secondary zinc minerals, most commonly smithsonite. The lead, silver, gold, and much of the copper were left behind at the site of the primary 
ore body, though commonly they too were leached and then redeposited as supergene minerals within the ore body. The process is described in detail by Loughlin (1918, p. 68-85). Much of the iron, some of the manganese and copper, and a little silver migrated with the zinc in the sulfuric-acid solutions and were redeposited with the zinc in the wallrock-replacement ore bodies. In the early stages, ferroan smithsonite (monheimite), manganosiderite, sauconite, and limonite were deposited with some copper carbonate. Later, when the early deposited carbonates were oxidized, purer drusy smithsonite, aurichalcite, hemimorphite, hetaerolite, chalcophanite, calcite, and more limonite were formed from them. Wallrock-replacement deposits in the late progressive stage of oxidation are not known in Colorado, but they have been described in the oxidized zinc deposits of Utah (Heyl, 1963).

The following analyses (table 5) of oxidized zinc wallrock-replacement ores from five deposits in Colorado show more variation in composition, except in zinc content, than is found in ores formed by direct replacement of the primary ores.

\section{TABLE 5.-Analyses of oxidized zine ore from wallrock-replacement deposits}

[Analyses in percent unless otherwise indicated. nd, not determined]

\begin{tabular}{|c|c|c|c|c|c|c|}
\hline & & & & Maid of & rin mine & \\
\hline & ore bin & mine & & $\begin{array}{c}\text { Brown } \\
\text { zinc } \\
\text { carbonate }\end{array}$ & $\begin{array}{c}\text { Gray } \\
\text { zine } \\
\text { carbonate }\end{array}$ & $\begin{array}{l}\text { Dooure } \\
\text { mine }\end{array}$ \\
\hline & 1 & 2 & & 3 & 4 & 5 \\
\hline 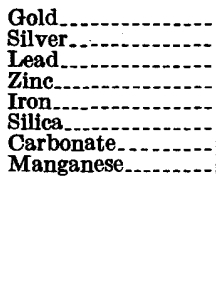 & $\begin{array}{l}10.005 \\
11.20 \\
43.0^{4} \\
8.1 \\
19.6 \\
26.7 \\
\text { nd }\end{array}$ & $\begin{array}{c}10.002 \\
14.50 \\
3.10 \\
21.64 \\
8.4 \\
21.0 \\
12.00 \\
9.24\end{array}$ & $\begin{array}{l}\mathrm{SiO} \\
\mathrm{Al}_{2} \mathrm{O}_{3} \\
\mathrm{Fe}_{2} \mathrm{O}_{3} \\
\mathrm{FeO} \\
\mathrm{MgO} \\
\mathrm{CaO} \\
\mathrm{MnO} \\
\mathrm{ZnO} \\
\mathrm{CO}_{2} \\
\mathrm{P}_{2} \mathrm{O}_{5} \\
\mathrm{H}_{2} \mathrm{O}+ \\
\mathrm{H}_{2} \mathrm{O}- \\
\mathrm{All} \text { others }\end{array}$ & $\begin{array}{r}4.1 \\
1.0 \\
13.4 \\
\text { None } \\
.6 \\
.4 \\
3.0 \\
46.2 \\
27.2 \\
\text { None } \\
2.5 \\
.9\end{array}$ & $\begin{array}{r}1.5 \\
.3 \\
\text { None } \\
9.0 \\
.5 \\
.3 \\
2.2 \\
49.6 \\
34.4 \\
.3 \\
1.0 \\
.5\end{array}$ & $\begin{array}{r}37.10 \\
14.18 \\
.30 \\
\text { nd } \\
1.10 \\
1.22 \\
.02 \\
28.19 \\
\text { None } \\
\text { None } \\
8.82 \\
8.90 \\
2.39\end{array}$ \\
\hline & & & Total & 399.3 & 399.6 & 100. 22 \\
\hline & & & Metallic zinc. & 37.1 & 39.9 & \\
\hline
\end{tabular}

1 Ounces per ton.

2 All others: $\mathrm{Na} 2 \mathrm{O}, 0.24 ; \mathrm{K}_{2} \mathrm{O}, 0.13, \mathrm{CuO}, 0.02 ; \mathrm{TiO}_{2}$, trace

3 Others looked for but not found are $\mathrm{PbO}, \mathrm{Ag}, \mathrm{SO}_{3}$, Cl; not looked for are $\mathrm{Na}_{2} \mathrm{O}, \mathrm{K}_{2} \mathrm{O}, \mathrm{BaO}, \mathrm{TiO}_{2}, \mathrm{FeS}_{2}$, $\mathrm{Au}$, and $\mathrm{CuO}$.

1. Representative sample from Madonna $O$ ore bin, Monarch district; rich hemimorphite (smithsonite ore) presumably mined from Madonna O level. Analyst: Deason and Nichols, Salt Lake City, 1954.

2. Selected dump sample of best oxidized zinc ore; mostly hemimorphite, but some rich smithsonite and chalcophanite; Leadville. Analyst: Deason and Nichols, Salt Lake City, 1955.

3. High-line level, Leadvilie. Analyst: R. C. Wells, U.S. Geological Survey laboratory (Emmons, Irving, and Loughlin, 1927, p. 236).

4. First intermediate above second level, Leadville. Analyst: R. C. Wells, U.S. Geological Survey laboratory (Emmons, Irving, Loughlin, 1927. p. 236).

5. White sauconite, layer 2-feet thick beneath silicified shale bed; Leadville. Analyst: M. K. Carron, U.S. Geological Survey laboratory (Ross, 1946, p. 419). For another analysis of similar material, see Loughlin (1918, p. 26, analysis 4). 
Five principal varieties of oxidized zinc ore formed by wallrock replacement are shown by the analyses. They are (1) mixed carbonate-silicate ore -a common shipping variety at Leadville and Monarch, (2) a heterogeneous mixture of silicate, carbonate, manganese-zinc oxides, silver-lead minerals, and gangue-typical of material recovered by culling old mine dumps at Leadville, Monarch, or Tomichi, (3) ferric zinc carbonate ore-typical of the rich wallrock ores that replaced earlier formed gray carbonate ores at Leadville, (4) gray zinc carbonate ore, which is deposited early in the oxidation process at Leadville as a replacement of manganosiderite and dolomite and is the host rock of the brown zinc carbonate ore represented by sample 3, and (5) zinciferous clay, most of which is fairly pure sauconite, deposited in large bodies in places at Leadville but never successfully produced as a commercial ore. Not shown by analyses are (a) red zinc carbonate ore, which is called zincite by some miners, and which is probably formed by replacement of limestone by intermingled iron- and zinc-rich solutions, (b) hemimorphite (zinc silicate ore without zinc carbonate), which is not very common, and (c) black zinc ore, which is a mixture of hetaerolite hydrohetaerolite, chalcophanite, and hemimorphite that was produced in small quantities at Leadville and occurs at Monarch at the Hawkeye mine (pl. 3, no. 87). Detailed physical and chemical descriptions of the types of ore represented by analyses 3, 4, and 5 are given by Loughlin (1918) under the following headings: "Brown carbonate ore" (p. 40-46), "Gray carbonate ore" (p. 36-40), and "Zinciferous clay" (p. 24-28); a physical description of black zinc ore is given by him also (p. 46-47).

The zinc content and type of ore vary from place to place within ore bodies and districts. In some stopes at Leadville, Horseshoe, and Monarch, ore bodies averaging more than 40 percent zinc have been mined. In other places-for example, the Carbonate Hill workings at Leadville (pl. 2) - much of the ore mined averaged 30 percent zinc. These high-grade ore bodies, however, are separated and rimmed by large quantities of lower grade material that contains between 10 and 20 percent zinc. Much of the ore produced during the 1920's at Leadville was from these marginal lower-grade bodies, and most of the hundreds of thousands of tons that still remain is in such unmined low-grade bodies. Some of the leaner bodies grade into limonite or dolomite in which the percentage of zinc declines outward to nothing. In others, both high-grade and low-grade, the zinc-rich bodies are sharply bounded by unaltered rock or manganosiderite. The boundary is marked by an altered transition zone a few inches to 1 or 2 feet wide separating the rock from the ore. 
BLANKET AND POCKET ORE BODIES

Secondary wallrock-replacement ore bodies are most commonly in blankets and pockets lying beneath or toward the lower end of oxidized silver-lead ore bodies. Commercial ore bodies of this type are restricted to limestones and dolomites. They vary in position, form, and composition; although most of them are small, some at Leadville and Monarch are very large and contain many thousands of tons of rich ore that needs but little further concentration.

Although nearly all oxidized zinc ore bodies of the wallrockreplacement type are closely associated with old silver-lead stopes, their exact positions, shapes, sizes, and grades vary greatly in relation to (a) distribution and abundance of zinc and iron sulfides in the primary ore bodies from which they are derived, (b) the composition of the carbonate-bearing wallrock in which they are deposited, (c) the presence or absence of impervious or nonreplaceable rock units, (d) the influence of local structures such as faults, fissures, joints, breccia zones, caves, bedding planes, or other solution channels or chambers.

For example, some primary ore bodies are rich in sphalerite and lean in the ubiquitous pyrite. Most of the zinc is usually carried only a short distance during oxidation and is redeposited as blankets (fig. $5 A$ ), pockets (fig. $5 B$ ), or casings (fig. 7) of concentrated oxidized zinc ore in the nearest favorable limestone wallrock. The great pocket and blanket ore bodies of Carbonate Hill at Leadville are of this type (Loughlin, 1918, pls. 7, 8). In other ore bodies the sphalerite, though abundant, is accompanied by even more abundant pyrite, as in most of the ore bodies at Leadville. In such deposits iron-rich supergene solutions usually carry most of the zinc fairly long distances from the source body before it is redeposited as less concentrated zinc carbonate. The solution channels between the primary and secondary ore bodies are commonly filled with siliceous iron oxides and clay. Ore deposits formed in this way occur at 50 or 100 feet below the old stopes in the Chrysolite mine at Leadville (Loughlin, 1918, fig. 7).

Where pyrite and sphalerite ores are adjacent to each other, the deposits formed in the wallrock may be separate but adjacent masses of smithsonite and limonite. Such discrete replacement bodies are known both at Leadville and Monarch, particularly in the Madonna mine (Dings and Robinson, 1957, p. 85).

In some places, such as in the Eclipse mine at Monarch, some of the wallrock of the original sulfide ores may have been rich in silica. In such places, limonite, jasperoid, and hemimorphite rather than the more common smithsonite may be deposited in large ore bodies. Smithsonite may have been deposited first and then replaced by the 


\section{PART 3. COLORADO}

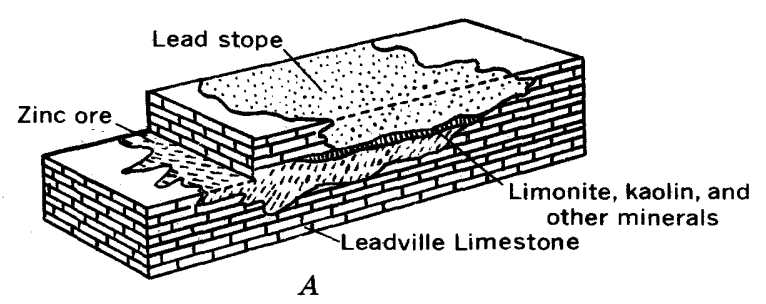

$A$
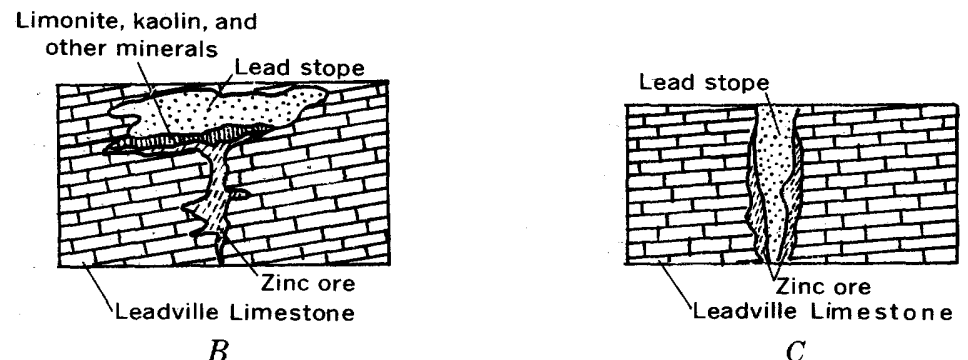

C

Figore 5.-Diagrams illustrating relation of oxidized zinc ore bodies to lead carbonate stopes in the Oro La Plata mine, Leadville. $A$, Oxidized zinc ore replacing dolomite beds beneath a blanket lead ore stope; $B$, oxidized zinc ore replacing rock along a barren fissure, and beds beneath a blanket stope ; $\sigma$, oxidized zinc ore replacing dolomite walls of a lead carbonate vein stope.

hemimorphite, but no certain evidence supporting this possibility was noted.

Impervious rock layers such as quartzite, shale, and porphyry may restrict replacement to the limestone above them, thus forming thin blanket oxidized zinc ore bodies, as at Leadville and Rico. If the zincbearing solutions can escape down through fractures in the impervious layers, then the solutions commonly do not deposit their zinc unless they reach another carbonate rock layer below, where low-grade ore deposits may be formed.

\section{REPLACEMENT . SHELLS AROUND PIPES OR MANTOS}

Zinc carbonate shells and casings surround the primary ore bodies at the Hilltop mine in the Horseshoe district, Park County (Behre, 1953 , p. 154-155). The main ore body is marked by the Big (or Hilltop) stope in the southern part of the mine. This ore body is cylindrical and its long axis extends N. $21^{\circ} \mathrm{E}$. It is 1,450 feet long and 70 feet in diameter, and it plunges gently northward. A typical ore shoot is composed of a central mass of galena associated with small quantities of sphalerite and is bordered by a thick sheathing of smithsonite. Similar sheaths and casings are common in the Ophir 
and Dry Canyon districts of Utah and have been described by Loughlin (1919).

\section{REPLACEMENT BODIES IN VEIN WALLS AND SECONDARY VEINS ALONG FISSURES}

Faults, fissures, and solution channels, where open, served to con. centrate the flow of supergene solutions, producing secondary vein (fig. $5 B$ ) or pipe deposits. If the faults and fissures were filled with impervious material or if they brought limestones against nonreplaceable beds, large thick oxidized zinc ore bodies were deposited in places by the impounded solutions. In some places, as in the Ora La Plata mine at Leadville, the walls of primary veins have been replaced by crusts of zinc carbonate (fig. $5 C$ ).

Other detailed descriptions of the occurrence of oxidized zinc deposits formed by wallrock replacement have been given by Loughlin (1918, p. 36-66), Emmons, Irving, and Loughlin (1927), Behre (1953), Dings and Robinson (1957), and Crawford (1913, p. 218-221, 242-243, 250 ).

\section{ORIGIN OF OXIDIZED ZINC DEPOSITS}

Nearly all the oxidized zinc deposits in Colorado have a common origin-that is, they are the result of the action of supergene oxygenated waters on primary deposits of sphalerite or of sphalerite mixed with iron, lead, copper, silver, and other metallic sulfides. The zincian siderite veins of the F. M. D. mine in the Malachite district may have been formed from carbonated solutions of hypogene epithermal origin as the final low-temperature stage of ore deposition.

\section{HYPOGENE DEPOSITS}

Zincian siderite veins of the F. M. D. mine near Evergreen in the Front Range of Colorado (pl. 1, no. 13) contain small crystals of pyrite, calcite, and radial crystal clusters of a zeolite (possibly stilbite) as evidence that they may be hypogene. The zincian siderite veins are late-stage deposits in narrow open fractures that cut across the wallrock and the massive sulfide deposit. They are clearly later than the main massive sulfide ore body and may have been deposited from fairly low temperature hydrothermal solutions during a final stage of mineralization or a later separate period of mineralization.

Deposits of lead carbonates that contain a little zinc and that may have been deposited directly from hydrothermal carbonated solutions as primary ores are known in Colorado at Ilse in the Wet Mountains (Hunter, 1914, p. 25-37; Emmons, 1896) and at the Lark mine (pl. 1, no. 111) on the southern slope of Red Mountain in the San Juan Mountains (Wilbur Burbank, oral communication, 1954). 


\section{SUPERGENE DEPOSITS}

Sphalerite is one of the more easily oxidized sulfides. Its oxidation and solution take place especially fast when it is in contact with other sulfides; for example, sphalerite in contact with marcasite is oxidized 10 to 14 times as fast as sphalerite that decomposes alone under the same conditions (Smirnow, 1954, p. 168), and ferroan sphalerite marmatite) oxidizes more rapidly than iron-free sphalerite. Sphalerite reacts easily with all the oxidizing agents and solvents that are common in the oxidation zone of a mixed sulfide deposit-oxygenated water, ferric sulfate, sulfuric acid and copper sulfate. Some of the more common reactions producing $\mathrm{ZnSO}_{4}$ in supergene solutions can be summarized as follows:

$$
\begin{aligned}
\mathrm{ZnS}+2 \mathrm{O}_{2} & =\mathrm{ZnSO}_{4} \\
2 \mathrm{ZnS}+2 \mathrm{Fe}_{2}\left(\mathrm{SO}_{4}\right)_{3}+3 \mathrm{3O}_{2}+2 \mathrm{H}_{2} \mathrm{O} & =2 \mathrm{ZnSO}_{4}+4 \mathrm{FeSO}_{4}+2 \mathrm{H}_{2} \mathrm{SO}_{4} \\
\mathrm{ZnS}+\mathrm{Fe}_{2}\left(\mathrm{SO}_{4}\right)_{3} & =\mathrm{ZnSO}_{4}+2 \mathrm{FeSO}_{4}+\mathrm{S} \\
\mathrm{ZnS}+\mathrm{H}_{2} \mathrm{SO}_{4} & =\mathrm{ZnSO}_{4}+\mathrm{H}_{2} \mathrm{~S} \\
\mathrm{ZnS}+\mathrm{CuSO}_{4} & =\mathrm{ZnSO}_{4}+\mathrm{CuS}
\end{aligned}
$$

Pyrite and chalcopyrite are associated with most of the primary zinc ores in Colorado and are abundant in some deposits, as at Leadville, Sedalia, and Monarch. Such sulfur-rich ores produce ferric sulfate, sulfuric acid, and copper sulfate in abundance-all very active agents in decomposing sphalerite. In the oxidation of such ores, the abundant free sulfuric acid and other sulfates in solution so exceed the $\mathrm{HCO}_{3}$ that they buffer its action and prevent the zinc from redepositing as zinc carbonate until it reaches the limestone wallrocks, which neutralize the strongly acid solutions. Thus, casings or pockets of zinc carbonate around oxidizing sulfide bodies, such as are abundant at Leadville, can be easily explained by differences in $\mathrm{pH}$ (or in the ratio of sulfate to carbonate) of interstitial waters during oxidation. In some deposits where the $\mathrm{pH}$ is low and silica is in excess, the solutions fall within the stability range of hemimorphite (Takahashi, 1960, p. 1098), and this mineral is deposited in the ore bodies prior to the deposition of smithsonite. Zinc sulfate, the product of the above reactions, is very soluble at room temperatures, especially in the acidic solutions that are typical of the oxidizing core of the sulfide ore bodies. Commonly the zinc solutions move downward and out from the primary ore body, leaving only cavities or limonite boxworks in place of sphalerite. The distance through which the leached zinc can travel in solution is dependent on the excess of sulfate ions in the acidic solutions and on how far they can travel before being neutralized.

In deposits in carbonate rocks where pyrite is not abundant enough to produce excess sulfate ions and sulfuric acid, this neutralization 
commonly occurs within the oxidizing ore body. The replacement of sphalerite in place by smithsonite is explained by neutral or alkaline ground water containing an abundance of carbonic acid in solution (200-300 parts per million) and normal free oxygen. This ground water is so buffered that the 18 or 20 parts per million of sulfate that can be formed from the much less available sulfur in pyrite-lean sphalerite ore bodies does not significantly change the $\mathrm{pH}$. Only a little zinc would probably go into solution, and the remainder would be converted in place to smithsonite (to hydrozincite in solutions with a pH greater than 8). The carbonated supergene waters are supplied by the limestone wallrocks or carbonate gangue. The oxidation and solution are accompanied by a reciprocal reaction of zinc sulfate (and commonly some ferric sulfate) with carbonic acid to form smithsonite (commonly ferroan). This process may involve little or no transportation of zinc from the original sphalerite.

Zine sulfate solutions in some deposits are formed during the oxidation of concentrations of sulfides, which acidify the solutions only locally; but they are quickly neutralized when they leave the oxidizing areas and enter adjacent masses of carbonate gangue, wall-rock, or areas of carbonated waters. Under such conditions, much of the zinc disperses in solution within short distances downward or outward but is redeposited as smithsonite (or smithsonite replaced by hemimorphite if silica in solution is abundant). This redeposition nearly always occurs within other parts of the same ore body, most commonly in marginal parts near the limestone or dolomite wallrocks or in parts where calcite or siderite gangue is abundant. Most of the oxidized zinc deposits that directly replace primary ore bodies probably are formed in this way. In the absence of available carbonate wallrock, gangue, or carbonated waters, the zinc commonly is dispersed from the ore body in solution and never is precipitated from the ground water, except as minor efflorescences of goslarite where evaporation takes place. The few exceptions in Colorado are discussed on pages C41-C42.

Where the zinc-bearing solutions migrate from the oxidizing sulfide ore body into the limestone or dolomite wallrock, the free sulfuric acid in the supergene solutions rapidly becomes neutralized; and much of the iron is deposited as limonite and jarosite, and the silica as jasperoid. Zones of such siliceous limonite lie between many of the original ore bodies and the secondary zinc ore bodies in the wallrock, but the zones are absent where no free sulfuric acid is present. The neutral zinc-bearing solutions then replace the limestone, dolomite, or (at Leadville) manganosiderite wallrocks with gray smithsonite and monheimite, in a volume-for-volume interchange. Some of this replacement probably is effected well above water table by downward- 
percolating solutions, but in other places it takes place in pockets where the solutions collect or are slow moving at or even below water table. In places where zinc-bearing solutions pass through feldspathic silica-bearing rocks, such as porphyry at Leadville, the free sulfuric acid and ferric sulfate in solution decompose sericite and feldspar and deposit silica, alumina, and zinc as sauconite in replacement bodies in limestone beneath the porphyry or in fissures within the porphyry.

As the remaining primary sulfides continue to oxidize, the ferric sulfate, sulfuric acid, and copper sulfates reach the gray zinc carbonate bodies in solution and leach the upper parts of the bodies to iron and manganese oxides and kaolin and move the zinc downward to the lower margins, where additional zinc carbonate is formed.

When most of the pyrite and chalcopyrite are leached and the remaining galena is armored from further reaction by cerussite, the solutions from the original ore body become lean in sulfuric acid and ferric sulfate ions, and carbon dioxide and oxygen become the principal remaining active agents. These two agents apparently oxidize the gray zinc carbonate and monheimite to limonite, hematite, chalcophanite, hydrohetaerolite and hetaerolite (at Leadville and probably at Monarch), and also strain and leach the gray smithsonite to more porous and vuggy brown and red smithsonite. Some of the leached zinc is redeposited in the vugs or in crystalline druses of lightcolored or white smithsonite after migration to nearby fractures and cavities. After carbon dioxide becomes less abundant, silica becomes an active acid radical and combines with the zinc to form hemimorphite; in places, aurichalcite and hydrozincite are deposited, perhaps under evaporating conditions. In areas of more arid climate, such as at the Mantle mine (pl. 1, no. 1) in the Yampa River canyon, the late stage of deposition is dominant and has produced abundant hydrozincite and hemimorphite. In places, still further oxidation leaches the zinc ores to limonite, calcite (and probably aragonite and nicholsonite), jasperoid, and drusy quartz. However, a little hemimorphite commonly is deposited in vugs as sparse crystals even in these latest stages. No deposits from which all the zinc has been removed were noted in Colorado.

The few oxidized zinc deposits in noncarbonate wallrocks were deposited under more unusual conditions. The simplest conditions caused the deposition and efflorescence of zinc sulfate, goslarite, by evaporation of descending zinc-bearing solutions-for example, the crusts of goslarite reported (Spurr and Garrey, 1908, p. 138-139) on the walls of the Burleigh Tunnel in the Georgetown-Silver Plume district (pl. 1, no. 11). More complex conditions exist in the zinc-rich lead-silver veins at Creede, and both goslarite and smithsonite are locally concentrated in the oxidized zones. The abundance of sphal- 
erite and sparsity of iron in the primary ores probably caused local saturation of the supergene solutions with zinc, and goslarite was deposited along with a little smithsonite, the needed carbonate being supplied in part from rhodochrosite in the gangue and in part from alkaline-earth carbonates in the decomposing feldspathic volcanic rocks of the vein walls.

Direct-replacement smithsonite boxworks and a few crystals of hemimorphite are deposited from similar sources in disseminated veins that cut rhyolite in the southern rim of the Creede caldera, as at the Bird Creek mine in the Spar district (pl. 1, no. 114). Stalactites and incrustations of zinc carbonate were deposited in the Victoria Tunnel near Georgetown (Spurr and Garrey, 1908, p. 138-139) from descending surface waters that had passed through several hundred feet of alkaline granite and granitic rocks.

In the silver-lead-zinc veins in quartz monzonite at Breckenridge (Ransome, 1911, p. 88), spongy brown smithsonite is deposited in veinlets, incrustations, and irregular masses at or below the water table, commonly coating partly leached sphalerite. Ransome suggests that the acid sulfate solutions containing zinc from the zone of general oxidation above the water table attacked siderite, particularly where the siderite is closely associated with sphalerite, and freed carbon dioxide, which, in turn, reacted with the zinc in solution to form smithsonite.

The following origin for the complex Sedalia copper-zinc deposit is suggested: The hypothesis of origin for the primary ores follows in part a proposal by Lindgren (1908, p. 165-166) that in Precambrian time a large body of diabase or gabbro intruded a series of metasedimentary rocks. Probably these rocks originally were dolomitic sandstones and shales, between Sedalia and Salida; the magma contained copper, zinc, and lead. A dike rich in metals and satellitic to the main igneous body was intruded, for the most part parallel to the strata, into the folded metasedimentary rocks at the Sedalia mine. Renewed dynamometamorphism followed the intrusion, converting the metasedimentary rocks into crystalline schists and the dike into amphibolite. The ore minerals were recrystallized, and metals migrated through the wallrocks. These older rocks, including the schists and mineralized mafic dikes, were later intruded by granites of Precambrian age, which further metamorphosed them near the granite contacts. Further dynamic metamorphism made the granites partly schistose. Granite pegmatite intrusions followed, and a large dike cut the Sedalia deposit in two, acting as a partial barrier during subsequent oxidation of the deposit. A later statement by Lindgren $(1933$, p. 803) places the alteration of the gabbro to amphibolite after intrusion of the granite. 
Oxidation has nearly completely converted the upper 200 feet of the deposit above the pegmatite-dike barrier into supergene minerals; only a little chalcopyrite and galena remain. Beneath the barrier, however, more sulfides are unaltered, including some sphalerite and pyrite. The first 100 feet have been leached largely to a gossan consisting mostly of limonite, jasperoid, malachite, and a little yellow earthy sulfate of lead and copper. The zinc that was abundant in the primary ores was almost completely removed by reaction with supergene solutions containing ferric sulfate, sulfuric acid, and copper sulfate, which were supplied by the oxidation of abundant chalcopyrite and pyrite. The resulting zinc sulfate was soluble in the acid solutions yielded by the norcarbonate wallrocks, and the zinc was dispersed downward through the partly leached and permeable mineralized zone below.

The supergene zinc and copper minerals were deposited in an ore body in the second 100 feet of the oxidized zone (above the pegmatite barrier) under chemical conditions that must have been complex. These unusual ores include anhydrous and hydrous zinc silicates, zinc carbonates and less common copper-zinc carbonates, copper sulfides and oxides, lead sulfates, and remnants of unleached hypogene sulfides. A possible hypothesis of genesis of the oxidized ores follows. Willemite, the earliest supergene zinc mineral, has been deposited in several localities elsewhere in the West as a secondary mineral under arid conditions, as in the Lemoigne district in Death Valley, Calif. (Heyl and Bozion, 1962). The large volume of iron and lead sulfates also suggests that the supergene acidic solutions which formed during oxidation of the sulfides were not abundant but seeped down slowly in small quantities to the pegmatite dam where they collected in an unusually concentrated form and reacted further with the sulfides. Some carbonate ions from vein calcite were available in the early stages of this period as the metal-rich solutions were accumulating above the pegmatite, as well as alkalies such as sodium from leaching of the pegmatite by the acidic solutions. Sodium and other alkalies accelerate the deposition of smithsonite in the presence of calcium carbonate (Smirnow, 1954, p. 171), and the reaction of the alkalies may account for the numerous crusts of ferroan smithsonite that coat the willemite. Limonite, jasper, anglesite, cerussite, manganesezinc(?) oxides, cuprite, and tenorite were also deposited. As the concentrated solutions slowly accumulated in this structural pocket, using up the available carbonate, the earlier formed willemite and smithsonite were etched, and the remaining sulfides were leached and replaced or coated by hydrozincite, aurichalcite, and rosasite(?). 
Hydrozincite and aurichalcite, like willemite, are typical of deposits formed in an arid climate during the late stage of oxidation. The climate of the area may have been arid at times in the early. Pleistocene (Lovering and Goddard, 1950, p. 19) and possibly also in parts of the Pliocene, about the time when the Arkansas River was eroding deeply into its valley during the last great mountain-building epoch of the late Tertiary and early Quaternary. The part of the ore body above the pegmatite dike may have been oxidized mostly during this period when the erosion by the river first exposed it, and the lower part (below the dike) may have been oxidized more recently, during the Pleistocene and Recent, as the river deepened its valley.

During the final period of oxidation, hemimorphite and malachite were deposited as end products, perhaps because the more humid climate during the rest of the Pleistocene and Recent provided sufficient moisture for the formation of these hydrated minerals. Hemimorphite is abundant in the partly oxidized ores beneath the pegmatite dike but not in the ores above the dike.

Oxidation, without question, is continuing at present; for the water table is now below the lowest tunnel level, which is 300 feet beneath the outcrop. The most recently formed oxidized minerals (for example, hemimorphite and malachite) are typical of a humid climate and are common in nearby mining districts such as Leadville and Monarch.

\section{RESOURCES}

Resource (and production) data for oxidized zinc ore are difficult to obtain and commonly are incomplete, except at Leadville, where such ores were major products of the district for 15 years. Little prospecting for such ore has been done since 1930. All of the zinc smelters and fuming plants in Colorado that were once readily available have been dismantled, and their abandonment has helped to make extraction of the ore unprofitable in this State, even though similar ores have been produced in Utah, Nevada, and Idaho in recent years.

"Ore" as used in this section and in the descriptive summaries of oxidized zinc deposits (p. C50-C88) includes all oxidized zinc-bearing material containing 25 percent or more zinc and oxidized zinc-leadbearing material containing a total of 20 percent zinc and lead combined, and commonly some silver. In a few places, "ore" includes zinc-bearing material containing sufficient copper, silver, or gold to enrich it to a grade that makes it potentially of commercial value.

All oxidized material that might conceivably be used commercially but is below the grades specified is classified as "zinc-bearing material." 
In this report, in appraisal of the districts and deposits, the term "resources" includes all available oxidized ore of commercial value in 1958 and oxidized zinc-bearing material that might conceivably be utilized in the near and more distant future. Known reserves are included, as well as reserves of ore and zinc-bearing material inferred to be present because of favorable geologic conditions, thus:

Oxidized zinc resources $=$ oxidized zinc, zinc-lead-silver, and zinc-copper ore reserves+marginal and submarginal oxidized zinc-bearing material+potential (the future possibilities of the district).

\section{KNOWN RESERVES}

Reserves of oxidized zinc, lead-zinc, and other types of commercial ore that could be shipped from Colorado at present (1964) are not very large, probably aggregating a little more than 800,000 tons, and most of this ore is inferred. ${ }^{2}$ Some of it contains too much iron or other impurities, is too remote from smelters, or has special smelting problems that prevent its shipment. The districts in which most of this commercial-grade ore remains are Leadville (widely scattered throughout the central part, especially in the Fryer Hill and Downtown areas), Horseshoe and vicinity, Monarch, and probably Aspen, Lenado, Spring Creek, Rico, Tincup, and Red Cliff.

The bulk of the known oxidized zinc resources of Colorado is (a) material that contains between 10 and 25 percent zinc, (b) material that contains between 5 and 20 percent zinc and lead combined, with or without some gold, silver, or manganese (too low grade to be recovered at a profit at the present time), and (c) material that contains copper and zinc. More than 2,200,000 tons of such low-grade material is known, mostly in the walls and dumps of mines at Leadville, Spring Creek, Aspen, Lenado, Sedalia, Monarch, and White Pine, and a little in many other districts west of the Front Range. Under favorable economic conditions, many dumps could be reworked, and small tonnages of shipping ore could be sorted from them. Much of the lowgrade material on the dumps will probably be reworked eventually; but, on the basis of recent experience, the bulk of it is submarginal, even under the best market conditions in recent years. This larger part of the dump material and the substantial tonnages of similar low-grade resources in the mines will probably become profitable sources of zinc again only after better milling and smelting processes are developed, especially if mills and smelters are, as formerly, within the Rocky Mountain area.

\footnotetext{
2 Inferred reserves may be concealed or poorly exposed and are estimated mainly on the basis of geologic data.
} 


\section{OUTLOOK FOR FUTURE DEVELOPMENT OF RESERVES}

The outlook for new discoveries of oxidized zinc-bearing ore is not nearly as favorable in Colorado as it is in some other States. Most of the largest deposits are in districts that were major sources of such ores during the period 1900-25 when the Rocky Mountain region was a center for the oxidized zinc mining and processing industry, or in districts which have been thoroughly explored because of associated ores valuable for other metals such as silver, lead, gold, and copper. For many years the decreased prices and demand for such ores have resulted in little incentive to prospect for or develop oxidized zinc ores.

Field examinations and available information suggest, however, that several districts may contain additional deposits, and also that oxidized zinc ore exists in other districts where it has previously been either unnoticed or considered to occur in negligible quantities. Aspen and nearby Lenado are examples of districts whose importance as producers of oxidized zinc ores is little known. They probably still contain some high-grade ore and large reserves of low-grade material that will average between 15 and 20 percent zinc and may contain enough lead and silver to be shipped as zinc-lead ores. Additional exploration in and around the old stopes would probably locate other oxidized zinc ore bodies.

Similiarly, additional ore probably remains in parts of several mines in the Monarch district. Examples are the Cree Camp mines; the caved upper workings of the Madonna mine above the fourth level, which, though zinc rich, apparently never were mined for zinc; and the upper parts of the Eclipse, Hawkeye, New York, Wilson, Silent Friend, and other mines.

New deposits of oxidized zinc ore may be found at Leadville in certain areas now flooded with water, such as in the Downtown area, but for the most part the district has been thoroughly explored. Loughlin (1926) makes many suggestions for further prospecting.

Some rich ore very probably can be found beneath the deepest workings in the Doctor mine in the Spring Creek district; but quartzite, which is reported to underlie the ore body, may cut off the ore body at a shallow depth.

Several districts that have produced very little or no oxidized zinc ore have deposits that may be large and rich enough for commercial production. Examples are the Rico, Tincup, Gold Brick, White PineTomichi, Taylor Park, Alma, Marble, Carbonate, and Cottonwood Creek districts.

Scattered throughout many mines and districts is a fairly large quantity of low-grade material that contains too little zinc to be shipped as oxidized zinc ore. This material contains sufficient lead 
and (or) copper and is locally associated with enough gold and silver to be shipped to slag-fuming plants under favorable price conditions as lead-zinc ore, copper-zinc ore, or lead-silver-copper-zinc ore. Slagfuming plants have been erected in recent years in California, Utah, Texas, and Montana, and much ore formerly not of commercial value has been shipped to them from nearby mining districts. At present, little or no ore is shipped from Colorado because of the long distance to the plants and the resulting high freight costs.

\section{GEOLOGIC FEATURES FAVORABLE FOR PROSPECTING}

Oxidized zinc deposits of commercial size and grade are closely associated with sulfide ore bodies that contain lead, lead-silver, leadzinc, copper-zinc, or zine that have been deeply oxidized and most commonly are in limestone wallrocks. Most of the deposits lie within or near the lead and lead-silver ore bodies, especially in their footwalls, or directly replace parts of them; but their exact positions, shapes, and sizes depend on too many factors to be determined without actual prospecting. Some general suggestions for prospecting follow :

1. New deposits of oxidized zinc ore may be found by field examination of oxidized lead-silver or lead deposits from which oxidized zine ores have not been produced, in districts where limestone is the main wallirock and where oxidation is deep. Examples are the Tincup, Rock Creek or Marble, Alma, Cottonwood Creek, and Rico districts. Some of the little-known districts near Crested Butte, Taylor Park, and the west slope of the Sawatch Range may contain undiscovered deposits. Oxidized zinc ores are common (but little worked) in some of the larger silver-lead districts where the sulfide ores have been mined, but they are in forms difficult to identify or, as at Aspen, to process.

2. Oxidized zinc deposits in places where the primary ores are lean in silver and lead but rich in zinc have seldom been worked because of their low market value and the high cost of mining and shipping from localities far from the smelters. The Rifle Creek, Massadona-Youghall, and the Gold Brick districts are examples.

3. Unmined pockets of high-grade oxidized zinc ore or large lowgrade deposits are known to many of the formerly productive districts such as Leadville, Monarch, Aspen, Lenado, Spring Creek, and Horseshoe. Similar pockets may be found by additional prospecting in the limestone footwalls and in the lower sides of old stopes where fractures, breccias, or limonite-replaced zones can be followed out from the primary ore bodies.

4. Old dumps or gob back-fills in lead-silver or lead mines may contain fairly large tonnages of oxidized zinc and zinc-lead ore that can easily be recovered by resorting and screening. 


\section{PROBLEMS OF IDENTIFICATION OF ORES}

Regarding the belated discovery of the largest deposits of oxidized zinc ore at Leadville, Colo., Loughlin (1918, p. 7-8) says:

After it was realized, in 1910, that large deposits of oxidized zinc ores were present in the Leadville district, considerable discussion arose over the fact that these ores had been so long overlooked both by the mining engineers and geologists who made frequent visits to the mines and by the mine officers and assayers who had been working in the ore and handling samples of it for several years. It must be admitted that the ore had been exposed both on the dumps and underground and all who have had an opportunity of finding it must share the blame of overlooking it.

And again he writes (p. 9):

The analyses of different vein materials [analyses in Emmons, 1886] show little or no zinc. A siliceous hematite from the Chrysolite mine, carrying $\mathbf{2 . 5 6}$ percent of zinc oxide was said to contain "a rather unusual percentage of zinc" ***. Even after some of the extensive zinc ore bodies had been exposed along drifts and other workings the strong resemblance of the reddish-brown ore to iron ore at one extreme and iron-stained limestone at the other and the close resemblance of the gray ore to partly leached but unstained limestone were hardly likely to lead one to suspect the presence of high-grade zinc ore.

The lack of recognition of oxidized zinc ores by miners, geologists, and engineers, as noted by Loughlin above, is even more prevalent today, because fewer people are familiar with oxidized zinc ores. These ores occur in large quantities in many districts-such as Aspen, Colo., and Park City, Utah-but they are recognized by only a few people. They have been missed in many mines where they are principal ores, even though the mines were examined by very competent men, many of whom unfortunately, know oxidized zinc, lead, and silver minerals only as the pretty, easily identified specimens in museums, college mineral trays, and mine offices.

Oxidized zinc minerals in direct-replacement ores commonly are in spongy boxworks, fine-grained masses, and thin gray, white, or dirtybrown crusts interstitial to galena, cerussite, and associated supergene minerals. Many of the zinc minerals resemble impure limonite, jasperoid, jarosite, siderite, calcite, dolomite, or earthy clay minerals. In some districts, such as Rifle Creek, the white material is hydrozincite; in others, such as Creede, some of it is impure goslarite. Without chemical or X-ray analysis, identification of the zinc minerals is difficult, at best.

Wallrock pockets of commercial oxidized zinc ore can rather easily be distinguished from waste in some places by physical appearance, such as recognizable oxidized zinc mineral grains or high specific gravity, but in many places the distinction is possible only after much careful sampling and analysis. The close resemblance of many oxidized zinc ores to iron-stained gangues and limestone is the main factor 
causing this difficulty in identification. Other factors are the varying degree of porosity of the ores and the varying percentages of iron and manganese oxide impurities. Brown, black, gray, or red zinc carbonate ores of commercial grades at Leadville, Monarch, and in the Mosquito Range may be practically identical in appearance with very low grade zinc-bearing material or even with iron or manganese ores. High-grade brown vuggy ore with hemimorphite crystal druses may have the same appearance as material leached to limonite with similar drusy crystals. Considerable experience at identification in the mines commonly results in the ability to detect the inconspicuous though critical differences between ore and waste. The main result of experience, however, is dependence on sampling and analysis rather than eye for the final distinction between ore and waste.

\section{OUTLOOK FOR FUTURE DEVELOPMENT OF MARKETS}

Very little market exists today in Colorado for ore that contains less than 25 percent zinc or 25 percent zinc and lead, even though ores containing as little as 16 percent zinc were profitably processed by the Western Zinc Oxide Co. plant at Leadville for at least a decade starting in 1915. Also, at present, few zinc-smelting companies will purchase small quantities of high-grade oxidized zinc ore because most of them have changed from the old horizontal retorts to modern vertical retorts that need a uniform grade and large tonnage feed to operate efficiently. The efforts of metallurgists to improve the smelting of zinc nationally have been largely focused on the abundant sulfide ores, although oxidized ores were long preferred by many smelters because they were much more easily processed in the horizontal retorts than were sulfide ores.

Market advantages were lost in Colorado by 1930 when all the zinc smelting and oxide plants had closed, in part because the youthful industry was unable to compete with the established smelters farther east, where the principal markets for the metal still remained in 1959. Consequently, most of the zinc produced and smelted in the West today is a byproduct of more profitable silver-lead or silver-lead-copper mining. Mining of zinc ores or lead-zinc ores, either sulfide or oxide that are lean in gold and silver is uncommon in the West except at a few localities such as Metalline Falls, Wash., and Hanover, N. Mex. The Gilman mine, the largest producer of zinc in Colorado in recent years, is able to operate continuously owing to the abundant lead, silver, copper, and gold in some of the sulfide ores. Low zinc-metal recoveries from oxide ores during smelting or fuming, the exhaustion of the largest and richest known reserves, and the difficulties in successfully concentrating the ores commercially have all contributed to the marketing problems. 
Some experimentation has been undertaken in recent years to develop ore dressing and concentration methods that would successfully process and concentrate low-grade oxidized zinc ores at low cost and with little loss of metal content. Caustic-leach processes that have worked well in pilot plants and laboratory experiments have been developed by the U.S. Bureau of Mines, by research laboratories, and by mining companies (Wendt, 1953, p. 84-90). Flotation and acid-leach processes are used successfully on oxidized and mixed oxidized sulfide ores in large-scale operations in Europe (Rey and others, 1954, p. 416-420; Straniero, 1954, p. 68-72). A similar industry has not been started in this country, partly because the iron-rich zinc ores common in the West are reported not to be amenable to the techniques developed in Europe. Commercial concentration plants to process oxidized zinc ores have not been erected because of a lack of known reserves sufficient to supply a large plant for a long enough time to amortize it, and because of generally unfavorable zinc-market conditions in the Nation since 1952, especially in the West.

\section{DESCRIPTIVE SUMMARIES OF OXIDIZED ZINC DEPOSITS BY DISTRICTS}

The oxidized zinc and zinc-lead ore deposits in Colorado are described by districts in the following pages. Selected individual deposits that have not been described in the section on types of deposits (p. C20-C38) are presented in some detail as examples; minor or little known districts are presented in a condensed format. The district descriptions are arranged by counties from north to south in the same order as listed on plate 1. All the described oxidized zinc mines or prospects are shown on plates 1,2, and 3. Within the Leadville area (pl. 2) the original mine numbering system used by Loughlin (1926, pl. 3) is retained for the hundreds of mines in that district. Place names not found on the illustrations cited in this report can be found on U.S. Geological Survey topographic quadrangle maps.

\section{MOFFAT COUNTY}

\section{MASSADONA-YOUGHAIL (DOUGLAS MOUNTAIN) DISTRICT}

Plate 1, nos. 1, 2

Location.-The district is in the northwest corner of Colorado, T. 6 N., R. 101-102 W., extending for about 12 miles along the south side of the Yampa River Canyon. Most of the deposits lie just south of the south boundary of Dinosaur National Monument. The Mantle mine, the principal working, lies 2 miles east of Johnson Draw in the upper canyon wall. 
Development and production.-The Mantle mine was discovered and located by John Mantle in the 1870's. The openings-three adits and a shaft containing a few hundred feet of drifts and small stopeslie successively above each other up a very steep canyon slope and extend westward into the hill. Shallow pits and cuts of the Oxide Metals Co. lie about 1 mile to the west. J. H. Ratliff of Vernal, Utah (oral communication, 1955), located other claims west of Johnson Draw for 11 miles to Red Rock Canyon. Several Ratliff prospects are in Hells Canyon west of Marthas Peak (pl. 1, no. 2).

The very small production of zinc that is reported from Moffat County probably came from the Mantle mine and from other properties in this district.

Geology and ore.-The Mantle mine workings are in a weak shear zone of nearly vertical fractures that strike between N. $40^{\circ}$ E. and N. $60^{\circ}$ E. in limestones of Mississippian age. The shear zone is probably a subsidiary fracture to the east-striking steeply north-dipping Yampa Fault that lies about one-fourth mile to the north (Untermann and Untermann, 1954, figs. 8, 9). Details of the geology and ore at the Mantle mine have been previously described (p. C25-C26). The other deposits are in similar shear zones or in small pockets.

Oxidized zinc ore resources.-A small tonnage of rich oxidized zinc ore is available in the Massadona-Youghall district, and the possibilities are fairly good that other small deposits of high-grade ore similar to those already found may exist in this little-prospected area. Large deposits of these ores probably do not exist in the district.

\section{ROUTT COUNTY}

\section{HAHNS PEAK DISTRICT}

Plate 1, no. 3

Location.-The district is south of the Colorado-Wyoming border to the west of the main Park Range east of the village of Hahns Peak in T. $10 \mathrm{~N} ., \mathrm{R} .85 \mathrm{~W}$.

Remarks.-No certain oxidized zinc deposits are reported in the Hahns Peak district, which is best known for its production of other metals such as gold, silver, and lead. A fairly large tonnage of zinc sulfide concentrates was produced between 1932 and 1945 (Vanderwilt, 1947, p. 187). Limestones and quartzite of Paleozoic(?) age are reported to be east of Hahns Peak and to contain partly oxidized contact deposits and veins of silver-lead ores, probably with some oxidized zinc minerals (Lovering, T. S., oral communications, 1953, 1955). One such deposit, the Master Key, was being developed in 1920 (Weed, 1920, p. 548).

References.-Gale (1906), George and Crawford (1908), Vanderwilt (1947, p. 186-189). 


\section{GARFIELD COUNTY}

\section{CARBONATE DISTRICT}

Plate 1, nos. 4-7, 10

Location.-The district is in the southern part of White River Plateau in T. 3-5 S., R. 87-89 W., eastern Garfield County. The site of Carbonate is 22 miles by road from Glenwood Springs, but 13 miles due north of it, on the east side of Carbonate Ridge at an altitude of about 10,500 feet. It is 3 miles southwest of Heart Lake and can be reached by unimproved roads and trails starting 2 miles north of Dotsero and extending westward to Heart Lake and Carbonate Ridge. Some of the silver-lead mines and prospects (pl. 1, no. 5) are at the west and northwest edge of the old Carbonate townsite, and others are scattered throughout the southern part of the plateau; the larger ones are at the site of Fort Defiance in Dead Horse Canyon above Shoshone (pl. 1, no. 6), at the heads of Canyon and Johnson Creeks south of Carbonate (pl. 1, nos. 4, 7), and at the heads of Mitchell, Oasis, East No Name, and Cascade Creeks north of the Transfer Springs Ranger Station (pl. 1, no. 10). Probably the largest deposit in the district is the Windy Point (or Strong) mine, which is about 5 miles north of Glenwood Springs and 2 miles north of the Transfer Springs Ranger Station.

Development and production.-Although the area was prospected as early as 1879 , a report in 1881 that very rich silver ore had been discovered led to a large-scale mineral rush early in 1882 , when more than 2,000 men came to the area to prospect. They founded a town called Carbonate, the first county seat of Garfield County, but located only small deposits, widely scattered over the plateau; by the following winter most of them had become discouraged and left. Since then, prospecting and mining have been only sporadic; and production, mostly of gold and silver, has been small (Vanderwilt, 1947, p. 88). A few tons of oxidized zinc ore are reported to have been produced, probably in 1941 or 1942, from the Defiance group of mines and prospects (N. W. Bass, oral communications, 1954).

The workings visited are shafts, pits, adits, and trenches. All the workings are shallow and have little stoping and probably little production.

Geology and ore.-The small ore deposits are in fissure veins and weak stockworks that cut limestones probably of Devonian and of Mississippian age; many are in the Leadville Limestone; some are in the Chaffee Formation. The limestones dip very gently along the axial crest of the gentle White River uplift, which trends northwestward. A report by Bass and Northrop (1963) describes the geology of the Glenwood quadrangle. 
The Fort Defiance prospects are in weak stockworks in limestone, the main fractures of which strike eastward and northward and are mostly nearly vertical. Porous silicified breccia contains masses of cerussite surrounding a little unoxidized and silver-lean galena, chalcocite and malachite, spongy boxworks of limonite, and a very little smithsonite.

Many of the deposits near the site of Carbonate (fig. 6) are in thin vertical fissure veins peripheral to a small basaltic volcanic neck with a scoria core, probably of Tertiary age. The neck intrudes Leadville Limestone, which is locally metamorphosed to marble immediately adjacent to the contact with basalt; the veins, 6 inches to 6 feet wide, pinch and swell slightly along their traceable lengths of 150-1,000 feet and contain some smithsonite, a little cerussite and galena, jarosite, brown jasperoid, and calcite. A 3-foot channel sample across the middle vein at the prospect northeast of the west main shaft yielded the following results when partly analysed:

Partial analysis of 3-foot channel sample from a vein near site of Carbonate

[Analysis by Deason and Nichols, Salt Lake City, 1954]

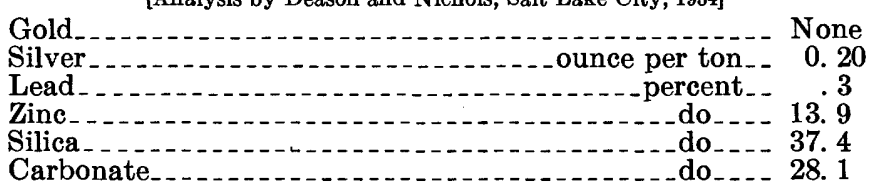

The Windy Point (or Strong) mine (pl. 1, no. 10) contains the largest deposits of oxidized ores known in the district. They are small but rich bodies of zinc-lead ores containing a little copper and very little silver in limestones and dolomites of the Chaffee Formation and the Leadville Limestone.

Oxidized zinc resources.-Known oxidized zinc deposits, though common and spread widely over the White River Plateau, are very small, except those at the Windy Point mine. Unless new deposits larger than those already known are found, the Carbonate district will probably never produce more than a few thousand tons of commercialgrade oxidized zinc ore.

\section{RIFLE CREEK DISTRICT}

Plate 1, nos. 8,9

Location.-The Sunshine Lode mine and nearby prospects of the Rifle Creek district are about 16 miles by road north of Rifle and about 2 miles north of the large vanadium mines on East Fork near the fish hatchery.

Development and production.-The Sunshine Lode mine was first opened as the Grandview mine in 1925 and was operated until 1932. The mine was reopened in 1940 by Mr. Lale Harmon, and it produced 


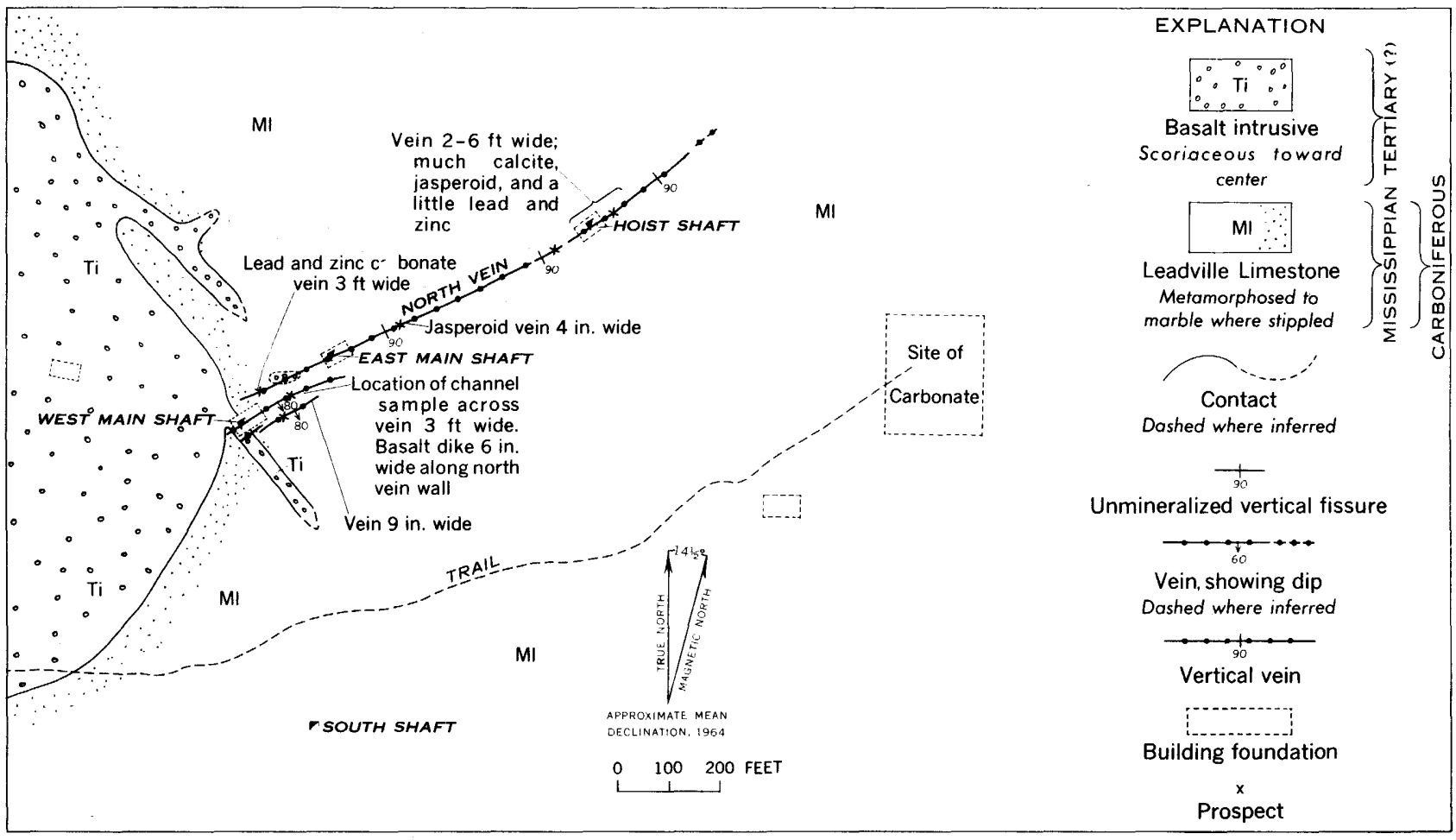

Mapped by A. V. Heyl and Priestly Toulmin, 3d, 1954

Figurm 6.-Sketch map of the geology and some of the oxidized zinc-lead deposits near Carbonate, Garfield County, Colo., SE $1 / 4$ SE $1 / 4$ sec. 34, T. 3 S., R. 89 W. 
periodically until 1951. No other base-metal properties in the district are known to have had production.

Recorded production of the Sunshine Lode mine follows (table 6). Nearly all the ore produced was oxidized and zinc rich. The ore shipped from 1941 through 1951 averaged 2.75 percent lead, 9.27 percent zinc, and 3.4 ounces of silver per ton.

\section{TABLE 6.-Recorded production of the Sunshine Lode mine}

[Data for years 1927, 1941, 1947, 1951 are in the Minerals Yearbook (U.S. Bur. Mines) for the respective years and are in terms of recoverable metals. The other years may be listed in terms of shipments to smelters, but this fact is not certain. Published with permission of the owner]

\begin{tabular}{|c|c|c|c|c|c|c|}
\hline Year & $\begin{array}{c}\text { Ore } \\
\text { (short tons) }\end{array}$ & $\begin{array}{c}\text { Gold } \\
\text { (ounces) }\end{array}$ & $\begin{array}{c}\text { Silver } \\
\text { (ounces) }\end{array}$ & $\begin{array}{l}\text { Copper } \\
\text { (pounds) }\end{array}$ & $\underset{\text { (pounds) }}{\text { Lead }}$ & $\begin{array}{c}\text { Zinc } \\
\text { (pounds) }\end{array}$ \\
\hline $\begin{array}{l}1927 \\
1941 \\
1942 \\
1946 \\
1947 \\
1951\end{array}$ & $\begin{array}{r}66 \\
26 \\
10 \\
707 \\
416 \\
37\end{array}$ & $\begin{array}{r}0.53 \\
1.25 \\
.35 \\
2.00 \\
1.00 \\
.74\end{array}$ & $\begin{array}{r}194 \\
91 \\
56 \\
1,944 \\
1,819 \\
158\end{array}$ & 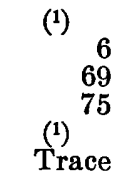 & $\begin{array}{r}10,142 \\
276 \\
404 \\
39,300 \\
22,900 \\
3,055\end{array}$ & $\begin{array}{r}(1) \\
7,974 \\
4,633 \\
128,675 \\
70,800 \\
9,756\end{array}$ \\
\hline Total & 1,262 & 5. 87 & 4,262 & 150 & 76,077 & 221,838 \\
\hline
\end{tabular}

1 Not reported.

The 920 feet of mine workings and stopes are shown on plate 5 , and the geology has been described (p. C32-C33).

Oxidized zinc ore resources.-Oxide and mixed sulfied-oxide ore comparable with that shipped or of slightly lower grade remains in many parts of the Sunshine Lode mine, especially in the walls of the largest stope of the main level and in the northern parts of the first and second levels (pl. 5). The fault zone is leanly mineralized with zine minerals nearly everywhere, including the northernmost and deepest workings, without marked change except for an increase in sulfides with respect to oxidized ores. Thus, the potential resources of low-grade oxide and mixed sulfide-oxide ores and mineralized material in the mine are probably fairly substantial. The oxidized ore is very lean in iron and thus amenable to fuming or fatty anime floatation processes, but the local areas of mixed sulfide-oxide ores would complicate ore dressing. The vein may be completely unoxidized a little farther north and a little deeper than the present workings.

References.-U.S. Bureau of Mines (1927, 1929, 1941, 1947, 1951).

\section{Clear CREek COUNTy}

\section{GEORGETOWN-SILVER PLUME DISTRICT}

Plate 1, nos. 11, 12

Location.-The district is in Clear Creek valley near Georgetown and Silver Plume. Within the district are the Victoria (Mendota 
vein) and Burliegh tunnels (Frostberg), whose specific locations are shown on plate 3 of Lovering and Goddard (1950) and in Spurr and Garrey (1908).

Development and production.--The district has had large production of silver but only mineralogic occurrences of oxidized zinc minerals.

Geology.-The roof and walls of the Vietoria Tunnel workings (pl. 1, no. 12) on the Mendota vein are covered with thick crusts and stalactites of postmining zinc carbonate at a depth of 450 feet beneath the surface. Chalcanthite was associated with the zinc carbonate in 1908 (Spurr and Garrey, 1908, p. 138-139). Spurr and Garrey found that descending meteoric waters contained "surprising" quantities of calcium and iron after having passed through a few hundred feet of alkaline granite and other granitic rocks of Precambrian age.

Nearby, Spurr and Garrey noted crystal crusts of goslarite in the Burliegh tunnel (pl. 1, no. 11) of the Frostberg vein at 750 feet below the surface. At a point where the descending solutions entered the drift, abundant crusts of yellow iron oxides were deposited, as well as basic copper sulfate and probably carbonate.

Oxidized zinc ore resources.-No reserves are known; occurrence is described only to show geology of oxidized zinc mineral deposition in noncarbonate rocks.

\section{JEFFERSON COUNTY}

\section{MALACHITE (PIPE) DISTRICT}

Plate 1, nos. 13, 13a

Location.-The F. M. D. mine is in a deep valley on a north tributary of Cold Spring Gulch, a main branch of Bear Creek, 4-5 miles northeast of Evergreen, Colo., just north of the center of sec. 25, T. 4 S., R. $71 \mathrm{~W}$. The Augusta mine is on Cub Creek, one-half mile south of Evergreen, Colo., in the SE $1 / 4$ sec. 10, T. 5 S., R. 71 W.

Development and proauction.-Both mines have produced some copper ore.

Geology.-Both deposits contain small quantities of unusual oxidized zinc minerals. The geology of F. M. D. mine, the mine containing zincian siderite of apparently hypogene origin, and the occurrence of supergene willemite at the Augusta mine have been described (p. C13).

Oxidized zinc ore resources.-None are known. The oxidized zinc occurrences are only of mineralogic interest.

References.-Lindgren (1908, p. 168-169), Lovering and Goddard (1950, p. 67-68, 279), Pough (1941, p. 97, tables 1, 2). 


\section{EAGLE COUNTY}

\section{RED CLIFF (GILMAN) DISTRICT}

Plate 1, no. 14

Location.-The Gilman mine and others of the Red Cliff district are along the Eagle River near Gilman and Red Cliff, Colo., in T. $6 \mathrm{~S} .$, R. $80 \mathrm{~W}$.

Development and production.-The Gilman mine of the Empire (New Jersey) Zinc Co. is the largest and most productive lead, zinc, silver mine in Colorado and has been for many years; it has also produced substantial quantities of gold and copper. Briefly, from 1912 to 1917 , inclusive, this district produced between 6,000 to 10,000 tons of oxidized zinc ores, mostly from the Black Iron and Iron Mask mines.

Geology and ore.-The oxidized zinc ores are smithsonite and hemimorphite replacing dolomite and manganosiderite in secondary wallrock pockets beneath the primary mantos of lead-zinc-silver ores. The deposits are very similar to those described by Loughlin (1918) at Leadville, but the oxidized zinc ores apparently are much less abundant than at Leadville. The main sulfide ore bodies replaced dolomitized Leadville Limestone and are arranged roughly in the shape of a three-pronged trident or spear pointed southwest or updip (Lovering and Tweto, 1947, p. 381). The prongs of the trident are three long mantos of zinc-lead-silver sulfides surrounded by manganosiderite casings. They turn downward and join in large steeply pitching pyritic copper-silver-gold chimneys. Supergene zinc ore pockets lie beneath and along the mantos near their outcrops, which are oxidized, and in places they are closely associated with supergene deposits of iron and manganese oxides.

Oxidized zinc ore resources.-Most of the richest oxidized zinc ores have been mined, but a fairly large tonnage of lower grade oxidized zinc material may remain in parts of the district. Such material may contain at least 15 percent zinc.

References.-U.S. Geological Survey (1912-1917), Lovering and Tweto (1947), Crawford and Gibson (1925).

\section{SUMMIT COUNTY}

\section{KOKOMO (TEN MILE) DISTRICT}

Plate 1, no. 16

Location.-The district is in the valley of Ten Mile Creek to the northwest and southeast of Kokomo, Colo., in T. 7 S., R. 79 W., and extends southward along the Ten Mile Range.

Development and production.-In 1911 the Kokomo Metals mine shipped 189 tons of ore, probably oxidized, that yielded 113,681 pounds 
of zinc (U.S. Geol. Survey, 1911). The district has been a commercially important source of lead, zinc, silver, and gold from both oxidized and sulfide ores.

Geology.-The largest production has come from irregular fingerlike shoots and mantos in thin limestone units interbedded with sandstone and shale of Pennsylvanian age. The oxidized zinc ores probably occur as secondary replacement pockets in the walls and floors of these primary replacement bodies.

Oxidized zinc ore resources.-Probably small, because the limestone units that are host rocks to the main ores are so thin that formation of large pockets of supergene zinc ores was undoubtedly prevented.

References.-Koschmann (1947), Koschmann and Wells (1946, p. 51-112).

\section{BRECKENRIDGE DISTRICT}

Plate 1, nos. 15, 17-20

Location.-Breckenridge, the county seat of Summit County, is a small mining town on the upper reaches of the Blue River in T. 6-7 S., R. $77 \mathrm{~W}$. Lode mines of the district lie mostly in the hills east and northeast of the town.

Development and production.-The district has been a commercially important source of gold and silver and also of zinc and lead. Zinc is not known to have been recovered from any of the oxidized ores that have been produced, but some of the oxidized ores mined for gold, silver, and lead probably contained sufficient zinc to be worthy of recovery.

Geology and ore.-Veins and lodes of gold and of lead, silver, gold, and zinc are in quartz monzonite porphyry of Tertiary age and in quartzite and silicified shale of Mesozoic age. The veins are commonly oxidized to about 300 feet in depth, and the greatest depth is under ridge crests. According to Ransome (1911), the normal sequence of minerals in the veins, from the surface downward, is as follows :

(1) Soft heavy yellowish claylike ore composed largely of silver- and gold-bearing earthy lead carbonate and, in places, a few residual nodules of galena.

(2) Mostly oxidized lead-silver ore; galena only partly oxidized, pyrite mostly altered to limonite; sphalerite altered to smithsonite and limonite, and much zinc removed from the veins by solution.

(3) Partly oxidized lead-silver-zine sulfide ore; galena is abundant, and a little spongy smithsonite is found replacing part of the sphalerite. 
Smithsonite probably is in the oxidized parts of most of the zincrich veins. Smithsonite is reported in local abundance at the Cashier, Rock Hill, Royal Tiger, Sallie Barber, and Wellington mines (pl. 1, nos. 15, 17-20).

Oxidized zinc ore resources.- Some of the oxidized ore apparently contained between 5 and 15 percent zinc. After 1900, producers were penalized for shipping zinc-bearing oxidized ore if it contained more than 7 or 8 percent zinc. Prior to 1900 most of this ore was accepted without penalty, and the zine was lost in the fumes and slags. Probably most of this oxidized ore was mined many years ago for its lead, silver, and gold; but some may have been left unmined in the old stopes because it was uneconomic at the time. Ransome (1911) apparently saw such ores in several of the mines long after the richest zinc-lean ores had been mined. The quantity that might still remain is not known.

References.-Ransome (1911), Lovering (1934), and Emmons (1917).

\section{PITKIN COUNTY}

\section{LENADO DISTRICT}

Plate 1, nos. 21, 27

Location.-The district is on Woody Creek about 5 miles northeast of Aspen and is easily accessible by road about 7 miles up Woody Creek from Roaring Fork to the old camp called Lenado or Woody (not Woody Creek).

Development and production.-Silver-lead-zinc mines at Lenado, especially the Leadville and Aspen Contact mines, have produced a fairly large quantity of lead-silver ore. In addition, more than 1,500 tons of partly oxidized zinc-lead ore that averaged about 36 percent zinc and contained 9 to 25 percent lead and 3 to 6 ounces of silver per ton was mined from the Aspen Contact mine in 1919, 1920, 1925, and $1926 .^{3}$ Details of this production are given in table 7. Much other oxidized zinc ore was mined and discarded on the dumps after sorting. The entrances to both mines were caved when visited in 1955 .

-Geology and ore.-Ore deposits of the district are satellitic to, and closely resemble, those at nearby Aspen, Colo., which have been described previously (p. C26-C28). Ore bodies are in thick veins of zinc sulfide (locally rich in silver and lead) in a major high-angle fault that strikes northeastward between limestone and quartzite of Carboniferous age. The sides and upper parts of the veins are oxidized to hemimorphite, gray smithsonite, dark-gray silver-rich cerussite, and limonite. A partial analysis representing the average of 20 shipments of this ore has been given previously (p. C28).

${ }^{3}$ Published with permission of the property owner. 
Oxidized zinc ore resources.-Much oxidized zinc ore remains in the fairly large dumps. Much of the ore could probably be shipped without further sorting during periods of favorable economic conditions, as the dumps contain an estimated 6 to 20 percent zinc and lead and a little silver. Some sorting and screening could easily upgrade the dump material. The owners, the Herron Brothers, stated (oral communication, 1956) that shipments they made from the Aspen Contact dumps contained 11 to 16 percent zinc, 5 to 6 percent lead, and a few ounces of silver per ton. They also stated that a fairly large quantity of such ore remains in the mine, as well as some richer ore similar to that shipped in 1920-26.

References.-Spurr (1898, text, atlas; 1909), Vanderwilt (1935), Rohlfing (1928).

\section{ASPEN DISTRICT}

Plate 1, nos. 22-26, 28, 30

Location.-The district is at Aspen, Colo., and extends southward for 5 miles and northeastward for about 2 miles.

Development and production.-Although one of the largest and most productive silver-lead districts in Colorado, the Aspen district has not produced much ore since the 1920's. The first recovery of zinc from oxidized ores in Colorado was from ores mined here about 1900. The history of this production is given in the section "Development" (p. C5-C7).

After the early period of silver-zinc-lead ore production, oxidized zinc and zinc-lead ores containing silver were produced from Aspen at various times from 1911 to 1926 . Production data for several of the mines were supplied by the Herron family, who owned many of the mines and mine records in the district in 1956, and these data are published in table 7 with the Herrons' permission. Other mines in the district may have produced during this same period, but specific production records were not available.

Geology and ore.-The geology of the oxidized zinc deposits at Aspen is described in the section "Oxidized massive bodies" (p. C26C28).

Oxidized zinc ore resources.-When the zinc-rich ore bodies were mined prior to 1930 , the parts richest in zinc, lead, and silver were selected by very irregular stoping; material in the leaner parts was left in the mines or was thrown on the dumps after hand-sorting. Very large quantities of oxidized zinc-lead ore, locally containing silver, remain in the district. Some of the largest bodies are in the Smuggler-Molly Gibson (fig. 4) and Great Western mines. Much of the ore is probably close in grade to a random grab sample from the Smuggler mine that contained 16.1 percent zinc (table 3, analysis 1 ). The analyzed sample is equivalent in grade to the oxidized zinc- 
TABLE 7.-Production of oxidized zinc-bearing ores from several mines at Aspen and Lenado, 1911-26

[Published with permission of John and William Herron, property owners]

\begin{tabular}{|c|c|c|c|c|c|}
\hline \multirow[b]{2}{*}{ Mines } & \multirow[b]{2}{*}{ Years } & \multirow{2}{*}{$\begin{array}{l}\text { Total zinc, } \\
\text { zinc-lead, } \\
\text { silver, silver- } \\
\text { lead-zinc ores } \\
\text { treated } \\
\text { (short tons) }\end{array}$} & \multicolumn{3}{|c|}{ Grade of ore } \\
\hline & & & $\begin{array}{l}\text { Silver } \\
\text { (ounces } \\
\text { per ton) }\end{array}$ & $\underset{\text { (percent) }}{\text { Lead }}$ & $\underset{\text { (percent) }}{\text { Zinc }}$ \\
\hline $\begin{array}{l}\text { Smuggler (opencut and shallow workings } \\
\text { near shaft) }\end{array}$ & \multirow[t]{2}{*}{$\begin{array}{l}1911 \\
1912 \\
1913 \\
1914 \\
1915 \\
1916 \\
1917 \\
1918\end{array}$} & $\begin{array}{r}40 \\
114 \\
53 \\
107 \\
35 \\
19 \\
89 \\
185\end{array}$ & $\begin{array}{c}13 \\
1.6-22 \\
8-33 \\
54 \\
54 \\
17.3 \\
8-32 \\
9-35\end{array}$ & $\begin{array}{c}14 \\
4-14 \\
5-17 \\
8.8 \\
4.5 \\
19.7 \\
4-7 \\
2-7\end{array}$ & $\begin{array}{c}8.5 \\
9-41 \\
3-12 \\
3.5 \\
3.1 \\
29.4 \\
10-19 \\
3-12\end{array}$ \\
\hline Total ore & & 642 & - & 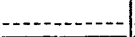 & 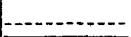 \\
\hline Great Western & \multirow{3}{*}{$\begin{array}{l}1916 \\
1913 \\
1914 \\
1915 \\
1916 \\
1917 \\
1918 \\
1919\end{array}$} & 24 & 4.1 & 15.3 & 46.7 \\
\hline Late Acquisition . . . & & $\begin{array}{r}67 \\
297 \\
214 \\
139 \\
65 \\
96 \\
89\end{array}$ & $\begin{array}{c}3 \\
2.2-8.8 \\
2.6-8.7 \\
2.7-7.8 \\
2.9 \\
1.5-3 \\
1.5-5.5\end{array}$ & $\begin{array}{c}7.1 \\
6-14 \\
11-16 \\
8-23 \\
6.7 \\
3-8 \\
4-14\end{array}$ & $\begin{array}{c}33.2 \\
26-35 \\
15-37 \\
17-30 \\
27.1 \\
28-32 \\
9-32\end{array}$ \\
\hline Total ore & & 967 & $-\cdots$ & - & 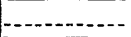 \\
\hline Durant.............. & \multirow[t]{2}{*}{$\begin{array}{l}1912 \\
1913 \\
1914 \\
1915\end{array}$} & $\begin{array}{r}1100 \\
812 \\
90 \\
281\end{array}$ & \multicolumn{3}{|c|}{ (grade not given) } \\
\hline Total ore & & 1,283 & 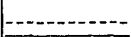 & 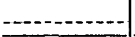 & 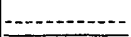 \\
\hline \multirow[t]{2}{*}{ Aspen Contact, Lenado } & \multirow[t]{2}{*}{$\begin{array}{l}1919 \\
1920 \\
1925 \\
1926\end{array}$} & $\begin{array}{r}3 \\
656 \\
512 \\
424\end{array}$ & $\begin{array}{r}6.7 \\
2.6-5.4 \\
3.3-6.9 \\
3.0-11.1\end{array}$ & $\begin{array}{c}22.8 \\
10-21 \\
10-20 \\
\theta-24\end{array}$ & $\begin{array}{l}10.4 \\
37.4 \\
35.8 \\
34.3\end{array}$ \\
\hline & & $\begin{array}{l}1,595 \\
4,511 .\end{array}$ & & $-\ldots-\ldots$ & 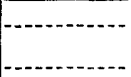 \\
\hline
\end{tabular}

1 Estimated from available information.

lead ores shipped in recent years to Utah, California, and Montana smelters having fuming plants; though manganiferous, it is not so rich in iron as to be unusable. Other bodies besides those known probably exist in the mines of the district.

Many large mine dumps remain, most of which contain an estimated 1 to 3 percent zinc and lead combined, 1 to 4 ounces of silver per ton, and some manganese. Much of this material is in the form of oxidized minerals that might be recovered at some future time. A few of the mine dumps-probably totaling material in excess of 500,000 tons - are richer and are estimated by the writer to contain more than 5 percent combined lead and zine and 1 to 5 ounces of silver per ton. As of 1956, small but rich dumps that contained between 8 and 19 percent combined zinc and lead remained in places. In addition, a very large tonnage of lean zinc-bearing manganoan 
dolomite and manganese oxide is reported by local mining men in Tourtellotte Park south of Aspen.

References.-Spurr (1898, text, atlas; 1909), Vanderwilt (1935), Rohlfing (1938), Volin and Hild (1950).

\section{MONTEZUMA AND ASHCROFT DISTRICTS}

Plate 1, no. 29

Location.-The Montezuma district is 4 miles southwest of Ashcroft in southernmost Pitkin County, on the northeast flank of Castle Peak at an altitude of 12,500 feet. It is accessible by jeep roads from Ashcroft. The Ashcroft district is in the ridges east of Ashcroft.

Remarks.-Mining men at Aspen report that oxidized zinc ores occur in some quantity at the old, long-idle Montezuma mine, the principal productive property of this district. The nearby Ashcroft district is reported to have some oxidized zinc minerals.

\section{LAKE COUNTY}

\section{LEADVILLE (CALIFORNIA) DISTRICT}

Plate 1, no. 38 ; figure 2

Location.-The many mines of the district are in Leadville and east of it nearly to the base of the high main ridge of the Mosquito Range. Although officially called the California district, it is now almost universally known as the Leadville district.

Development and production.-The numerous mines and ore bodies of the Leadville district are shown on plate 2, and those that are known to contain or to have produced oxidized zinc ores are indicated. The reader is referred to Emmons, Irving, and Loughlin (1927), Loughlin (1918), and Henderson (1926, especially p. 130-176) for details on the discovery, development, and production of oxidized zinc ores and the history of the mining district. Table 8 shows the production of oxidized zinc and lead-zinc ores from the district.

Leadville is by far the most productive source of oxidized zinc ores of supergene origin in the United States. The production shows a rapid increase to its maximum in 3 years and then a gradual decline until 1926, when the Western Zinc Oxide Co. plant was closed permanently. Since that time, production has been very small and sporadic, mostly from ore re-sorted from the old mine dumps.

The richest ore was produced in 1910, the year of first production of zinc from oxidized zinc ore. This ore averaged 32.2 percent zinc, but the grade slowly declined to between 17 and 20 percent zine in later years. In fact, most of the oxidized zinc ores that were produced so profitably in the Leadville district for 16 years did not contain the 25 percent zinc now considered a minimum grade for 
such ores; nor did smelters pay the miners extra, as many have in recent years, for lead, silver, or copper, although most of the oxidized ores contained 1 to 3 percent lead and 1 to 4 ounces of silver per ton. and some contained recoverable copper.

TABLE 8.-Oxidized zinc ores produced in the Leadville district 1910-50

[ From Emmons, Irving, and Loughlin (1927) and U.S. Bur. Mines Minerals Yearbooks for years 1926-50, inclusive]

\begin{tabular}{|c|c|c|c|c|}
\hline Year & Ore (short tons) & $\begin{array}{l}\text { Recovered zinc } \\
\text { (pounds) }\end{array}$ & $\begin{array}{l}\text { Recovered lead } \\
\text { (pounds) }\end{array}$ & $\begin{array}{l}\text { Average percent } \\
\text { zinc in original } \\
\text { ore }\end{array}$ \\
\hline $\begin{array}{l}1910 \ldots \ldots \\
1911 \ldots \ldots \\
1912 \ldots \ldots \\
1913 \ldots \ldots \\
1914 \ldots \ldots\end{array}$ & $\begin{array}{r}8,059 \\
83,905 \\
142,782 \\
135,760 \\
113,881\end{array}$ & $\begin{array}{r}4,310,500 \\
45,143,685 \\
71,682,667 \\
63,340,473 \\
46,791,046\end{array}$ & $\begin{array}{l}(1) \\
(1) \\
(1) \\
(1) \\
(1)\end{array}$ & $\begin{array}{l}32.2 \\
31.05 \\
29.2 \\
27.45 \\
24.3\end{array}$ \\
\hline $\begin{array}{l}1915 \\
1916 \\
1918 \\
1919\end{array}$ & $\begin{array}{l}82,592 \\
85,513 \\
69,238 \\
21,292 \\
16,542\end{array}$ & $\begin{array}{r}30,684,552 \\
30,174,903 \\
21,116,726 \\
6,351,683 \\
4,592,170\end{array}$ & $\begin{array}{l}\text { (1) } \\
(1) \\
(1) \\
(1) \\
(1)\end{array}$ & $\begin{array}{l}22.48 \\
21.52 \\
19.84 \\
18.64 \\
17.80\end{array}$ \\
\hline $\begin{array}{l}1920 \\
1921 \\
1922 \\
1924\end{array}$ & $\begin{array}{r}16,726 \\
4,277 \\
11,343 \\
20,304 \\
18,801\end{array}$ & $\begin{array}{l}5,840,835 \\
1,200,000 \\
3,876,000 \\
6,732,000 \\
5,796,000\end{array}$ & $\begin{array}{l}(1) \\
(1) \\
(1) \\
(1) \\
(1)\end{array}$ & $\begin{array}{l}21.79 \\
17.97 \\
21.36 \\
20.72 \\
19.56\end{array}$ \\
\hline $\begin{array}{l}1925 \\
1926 \\
1927 \\
1929-30\end{array}$ & $\begin{array}{r}11,782 \\
8,149 \\
311 \\
2100 \\
\text { None }\end{array}$ & $\begin{array}{l}3,832,000 \\
2,413,000 \\
\quad 129,000 \\
\quad(1)\end{array}$ & $\begin{array}{l}(1) \\
(1) \\
(1) \\
(1) \\
(1)\end{array}$ & ${ }_{(1)}^{20.26} 19.0$ \\
\hline $\begin{array}{l}1931-39 \\
1940 \\
1941 \\
1942 \\
1943\end{array}$ & $\begin{array}{r}\text { (3) } 27 \\
\text { None } \\
4556 \\
4318\end{array}$ & $\begin{array}{r}6,519 \\
415,559 \\
49,906\end{array}$ & $\begin{array}{l}(1) \\
(1) \\
(1) \\
40.822 \\
29,823\end{array}$ & $(1)$ \\
\hline $\begin{array}{l}1944{ }^{5}{ }^{5} \\
19455^{5} \\
1946 \\
19475^{5} \\
1948 \\
1949 \\
1950\end{array}$ & $\begin{array}{r}4478 \\
4194 \\
4694 \\
495 \\
41,039 \\
2448 \\
4331\end{array}$ & $\begin{array}{r}190,596 \\
47,570 \\
57,802 \\
19,335 \\
358,235 \\
(1) \\
132,114\end{array}$ & $\begin{array}{r}58,382 \\
32,600 \\
109,577 \\
21,180 \\
221,225 \\
(1) \\
81,572\end{array}$ & $\begin{array}{l}\text { (1) } \\
(1) \\
(1) \\
(1) \\
(1) \\
\text { (1) } \\
\text { (1) }\end{array}$ \\
\hline $\begin{array}{l}\text { Total production } \\
1910-50\end{array}$ & 885,137 & $\begin{array}{r}355,284,876 \\
(177,642 \text { tons })\end{array}$ & $\begin{array}{r}595,181 \\
(297 \text { tons })\end{array}$ & \\
\hline
\end{tabular}

1 Not recorded. No records of lead recovery from 1910 to 1941 . Probably very little lead was recovered prior to 1930 from oxidized zinc ores.

2.

No data listed, but there was probably some production in 1931, 1936, and 1937; without question, there was production in 1939 . Some of this ore was lead-zinc oxidized ore.

4 Probably mostly oxidized ores, but may include some sulfides. In this period, payments started on lead and other metals in oxidized zinc ores at many smelters.

$s$ For period 1942-50, inclusive, lead-zinc and zinc ore shipments were mostly from Leadville mine dumps. After 1947 some gold, silver, and copper were also recovered from the ores. 
Geology and ore.-Most of the oxidized zinc ore at Leadville was deposited as large supergene replacement bodies after migration of zinc from the oxidizing hypogene sulfide deposits into the Manitou Formation, Fremont Limestone, Chaffee Formation, and Leadville Limestone wallrocks and into large manganosiderite bodies surrounding the sulfides. Such deposits have been previously described in this report (p. C33-C38) and, in detail, by Loughlin (1918) and Emmons, Irving, and Loughlin (1927, especially pp. 231-246, 258-272), so that no further description is necessary. It should be kept in mind while reading these descriptions that most of the oxidized zinc ores contain a little lead, copper, and silver, and locally much manganese and that the ores remaining are mostly leaner than those already produced, probably averaging about 14 percent zinc. The presence of lead and silver may make many of them shippable as zinc-lead ores where they are not rich enough to be produced as zinc ores, but much sampling and analysis is necessary to establish better the average lead, silver, and copper content.

Oxidized zinc ore resources.--The very extensive past exploration and mining for all kinds of ore, including oxidized zinc ores, and the fact that market conditions for the ores were formerly more favorable than at present suggest that most of the accessible high-grade ores have been mined. Nearly all the oxidized zinc ores mined in the future will probably be lower grade and less accessible and be produced under more difficult conditions than previously. Much of the district has long been idle, especially in the Carbonate Hill, Fryer Hill, and Downtown Leadville areas where the zinc carbonate ores were most abundant. In large parts of these areas the workings are so badly caved that a resumption of mining would be very costly. The Leadville Drainage Tunnel has helped dewater some of the northwestern parts of these areas, but it has not helped enough to cause a significant revival of the district.

There are reasons to believe, however, that the productive areas of oxidized zinc ores in the Leadville district may still be enlarged and that some good ground heretofore overlooked or unrecognized may be found within the already developed areas. The ores are notably difficult to identify, and in many places lie far enough out from the silver-lead ore bodies to avoid discovery unless specific exploration is made for them. When the zinc deposits were recognized in 1910, large areas of old workings were already inaccessible, and some of these were never reopened and reexplored for oxidized zinc ores. Also, it is well established that in many places the oxidized ores extend below the present depth of the mines, especially in the Downtown area, but the abundance of water has prevented any deeper 
mining. Emmons, Irving, and Loughlin (1927, p. 323-326), Loughlin (1926), and Behre (1953, p. 116-119) point out many areas worthy of more investigation for both oxidized and sulfide ores. Besides the areas of promising ground that are believed to exist and the developed and partly developed ore bodies that are minable, Loughlin (written communication, 1943) and others familiar with the district report that large quantities of low-grade material are available to be mined when higher prices or improvements in metallurgy make it profitable to treat them.

Very comprehensive and careful studies of the oxidized zinc resources in the Leadville district were made by U.S. Government Agencies during the planning stages of the Leadville Drainage Tunnel. The consensus of opinion at the time was that very large tonnages (about several hundred thousand to 1 millon tons) of oxidized zinc ore and of low-grade material that would average 14 percent zinc (and range between 10 and 25 percent zinc) are inferred to remain in the central Leadville district and eastward to the base of the main Mosquito Range. These reserves include a small but substantial tonnage of inferred ore containing 20 to 25 percent zinc that is scattered through many mines in the central Leadville district. The largest reserves of low-grade material are in the Carbonate Hill, Fryer Hill, Downtown, and Iron Hill areas; much of the richer ore is elsewhere. To those familiar with the district, these reserve figures may appear to be too high; however, they represent total resources-that is, shipping ore and low-grade material in accessible and now inaccessible ground.

Anyone planning to recover some of this large resource should keep in mind that much of it is at present inaccessible because of flooded, filled, or caved workings. Without question, some of the resources are permanently lost, whereas others are not economic under the most favorable conditions in recent years. At some future time, however, when the need develops and better mining recovery methods are known, much, and perhaps most, of this large zinc resource will probably be recovered.

References.-Emmons, Irving, Loughlin (1927), Loughlin (1918, 1926), Behre (1953), Argall (1911, 1914).

\section{MOSQUITO RANGE DISTRICT, INCLUDING SOME OUTLYING PARTS OF THE LEADVTHLE DTSTRICT}

Plate 1, nos. 31-35, 37

Location.-The area lies along the crest and steep western slopes of the main ridges of the Mosquito Range east and southeast of Leadville. 
Development and production.-Most of the mines in the district are small, owing in part to the size of the deposits but also to the difficulty of access and high costs of working. Some of the larger mines are the Continental Chief, Dyer, Liddia, and Helena, most of which produced some oxidized zinc ores. The quantity of oxidized zinc ore produced is not known, but it may have exceeded 1,000 tons.

Geology and ore.-The primary deposits are geologically similar to those of the main Leadville district and occur in veins, small bedded replacement pipes, or shoots (Behre, 1953), in favorable dolomite and limestone beds. Many of the deposits show some epithermal characteristics. High-temperature and contact deposits are absent, as are widespread replacement blankets such as those common in the main Leadville district. As in marginal or outlying deposits elsewhere, Behre points out, chalcopyrite, pyrite, manganosiderite, and silver minerals are less abundant; but barite is much more common, and sphalerite is less ferroan and lighter in color than the dark-brown or black sphalerite typical of the main Leadville district.

Oxidized zinc ores are common in many places, mostly as direct replacements of primary ores, in the form of porous brown or gray boxworks of smithsonite and hemimorphite that include partly oxidized grains of galena. Much more locally, chocolate-brown sauconite and a little aurichalcite, hydrozincite, chalcophanite, and hydrohetaerolite have been found (Behre, 1953, p. 92-93).

Oxidized zinc ore resources.-Behre (written communication, 1958) doubts that more than several thousand tons of oxidized zinc ore of commercial grade could be obtained from the Mosquito Range and Horseshoe districts and the southernmost part of the Leadville district. Probably less than one-third of this might come from the Mosquito Range district as defined in this report.

References.-Behre (1953), Emmons (1886).

\section{WESTON PASS DISTRICT}

Plate 1, no. 36

Location.-This small silver-lead-zine district is at the crest of Weston Pass in secs. 35 and 36, T. 10 S., R. 79 W., and secs. 1 and 2 , T. $11 \mathrm{~S}$, R. $79 \mathrm{~W}$. The district is accessible by 10 miles of dirt road eastward from U.S. Route 24 at a point 5 miles south of Malta.

Development and Production.-The district may have been discovered about 1890 (Behre, 1932, p. 73). Mining was most active between 1900 and 1905 and again between 1912 and 1916. During the latter period about 800 tons of oxidized zinc ore was shipped from the Ruby mine, and a little was shipped from the Cincinnati and Colin Campbell mines. One shipment of this ore in 1915 contained 22 per- 
cent zinc (U.S. Geol. Survey, 1915) ; but according to Behre (1932, p. 73), much of the remainder contained 35 to 40 percent zinc.

Geology and ore.-Bedded replacements of lead, silver, and zinc minerals are in blankets as much as 10 feet in thickness that lie in an ore zone that is about 170 feet above the base of the Leadville Limestone. The zone is traceable along its sinuous northwest trend for 6,800 feet (Behre, 1932, p. 67), but much of it is lean. Nearly all the ore mined is oxidized or partly so. The sinuous zone of mineralized dolomite extends westward through Weston Pass in a narrow open syncline whose northeastern side is displaced upward along a series of faults that are generally parallel to the fold.

The oxidized ores are mineralogically relatively simple, consisting mainly of cerussite, hemimorphite, smithsonite associated with a little chalcophanite(?), chalcedony, and limonite. The deposits are peripheral and are fairly similar to those at Leadville. The sulfide deposits are also mineralogically simple, and they lack high-temperature minerals; these epithermal qualities are even more marked here than in the Mosquito Range district to the north. The oxidized ores directly replace the sulfides and in places form casings around them. Most of the oxidized ores contain some lead (5 to 18 percent) and are lean in silver ( 0.3 to $3 \mathrm{oz}$. per ton).

Oxidized zinc ore resources.-This small district has never been worked to any extent because the small commercial-grade deposits are lean in silver and their location is relatively inaccessible. Other deposits like those mined probably exist, but careful prospecting by drilling is needed to find them (Behre, 1932, p. 75). The water table is shallow in the district, and this fact suggests that oxidized ores are absent in the deeper deposits, although oxidized ores extend far below the water table in places at Leadville. At best, the potential of the district is not very large.

\section{PARK COUNTY}

\section{AIMA (BUCKSKIN) DISTRICT}

Plate 1, nos. 39, 42, 43, 45, 45a

Location.- The district is west and northwest of Alma along Buckskin Creek and on the eastern slopes of Mount Bross and Mount Lincoln in T. 8 and 9 S., R. $78 \mathrm{~W}$.

Development and production.-The district was settled and prospected about 1861 and for many years was a major gold and silver district centered about the London mine and on the slopes of Mount Bross and Mount Lincoln. Oxidized zinc minerals occur in several parts of the district, but only one mine, the Nelson (pl. 1, no. 43), is known to have produced oxidized zinc ores. This mine produced in 
1909 and again in 1910, when one narrow-gauge car (21 tons) of oxidized zinc ore was shipped (U.S. Geol. Survey, 1910). Other mines were oxidized zinc minerals occur in some quantity are the Dolly Varden, Moose, Criterion, and possibly the Russia and Orphan Boy mines.

Geology and ore.-The geology of the district has been well described by Singewald and Butler $(1931 ; 1933 ; 1941$, especially pls. 1,2), and the mines and ore, in more detail, by Patton and others (1912). Most of the known oxidized zinc deposits are in limestones of Ordovician, Devonian, and Mississippian age that form the middle strata of a now thin, partly eroded cap of sedimentary rocks that cap, and dip gently eastward from, the summits of Mount Bross, Mount Lincoln, and Loveland Mountain. This cap of sedimentay rocks unconformably overlies granites and gneisses of Precambrian age. The silver-lead-zinc ores are in rich bedded replacement blankets in the limestones, and the oxidized zinc minerals have directly replaced the sulfide ores. Red and brown granular smithsonite and, less commonly, hemimorphite are closely associated with cerussite, galena, jarosite, limonite, cerargyrite, malachite, and pyrolusite.

Most of the ore has been mined for its silver and lead content, and some zinc-bearing areas that contain silver but are lean in lead are therefore left in the accessible workings. Two partial analyses of such zinc-silver-bearing material follow :

Partial analyses of zinc-silver-bearing material

[Analyst, Deason and Nichols, Salt Lake City, 1954]

\begin{tabular}{|c|c|c|}
\hline & $\begin{array}{l}\text { Dolly Varden } \\
\text { mine, 4ft } \\
\text { vertical chan- } \\
\text { nel across vein } \\
\text { of ore in up- } \\
\text { per open pit }\end{array}$ & $\begin{array}{c}\text { Moose mine } \\
\text { dump grab } \\
\text { sample from } \\
\text { main north } \\
\text { workings }\end{array}$ \\
\hline $\begin{array}{l}\text { Gold } \\
\text { Silver }\end{array}$ & $\begin{array}{r}\text { None } \\
9.05\end{array}$ & $\begin{array}{r}\text { Trace } \\
2,20\end{array}$ \\
\hline Lead & None & None \\
\hline Ging & 6. 1 & 9. 3 \\
\hline Silica _ _ $\ldots \ldots \ldots$ & 1.7 & 1. 6 \\
\hline Carbonate.... & 42.3 & 42. 1 \\
\hline
\end{tabular}

At the Criterion Group, low-grade oxidized material is estimated to average 7 percent zinc and 5 percent lead.

Oxidized zinc ore resources.-The primary lead-silver deposits in the Paleozoic limestones are similar to, but smaller than, many of those to the west at Leadville. Some of the deposits, although rich, are so high on the mountain sides that they are very difficult to work. The known remaining ores are fairly lean in zinc and lead but commonly contain sufficient silver to add substantially to their value. Some of the dumps, such as those at the Moose mine, apparently contain enough silver and zinc to be of economic interest for shipping, after re-sorting during periods of most favorable prices. 
Known reserves in the district are small, but the district is geologically favorable and apparently little prospected for oxidized zinc ores. Patton and others $(1912$, p. 223) pointed out long ago that the search for lead-silver ores had keen concentrated above the Parting Quartzite and that the underlying "white" (Manitou Formation) limestone was little prospected in 1912. Apparently it still is little prospected, and new lead, silver, and zine deposits, both oxidized and sulfide, may be found in these st]:ata, just as they were later found at Leadville.

Very probably no thorough search has ever been made for wallrockreplacement pockets of smithsonite in the limestones beneath and adjacent to the oxidized ore bodies, and the possibilities that such pockets exist seem good. The deposits west and southwest of Alma on Loveland and Pennsylvania Mountains should be examined carefully.

\section{HORSESHOE DISTRICT}

Plate 1, nos. 40, 41, 44

Location.-The district is on the eastern upper slope of the Mosquito Range from Mount Sheridan south to Horseshoe Mountain, all in Park County near the sources of Horseshoe Gulch. Behre (1953) includes some of these deposits in his Mosquito Range district.

Development and production.-The Hilltop mine was the most productive mine in the district. According to Behre (1953, p. 155156), it was discovered about 1875 and was most active from 1883 to 1892, from 1900 through 1916, and again from 1920 to 1923 . The ore mined in the lattermost period was largely sulfide.

Oxidized zinc ores were discovered in 1907 and were produced in quantity from the Hilltop mine from that year until 1916. The largest production was probably in 1910, when an estimated 1,000 tons of ore yielded 695,796 pounds of zinc. valued at $\$ 35,629$ (U.S. Geol. Survey, 1910). According to Behre (1953, p. 155), U.S. Geological Survey and U.S. Bureau of Mines records show that from 1901 to 1923, 2,530,935 pounds of zinc was produced. A large part of this was from oxidized zinc ores and zinc-lead ores, and the records suggest that production of these classes of ores was between 4,000 and 5,000 tons. Much of the oxidized zinc ore averaged 40 percent zinc. It is not known whether other mines in the district produced oxidized zinc ores, but an additional 500 to 1,000 tons probably was produced somewhere in the county, from either the Horseshoe or the Alma district.

Geology and ore.-The Hilltop mine lies in a small exposure of Leadville Limestone and Dyer Member in early white porphyry; all units dip gently eastward. The rocks are cut by a series of north- 
ward-striking westward-dipping normal faults that converge and end against the northwest-striking Fulton fault at the north end of the mine (Main Shaft No. 2). All these faults show strong strike-slip components. The main ore body is a cylindrical pipe that trends and plunges gently northward for 1,450 feet along the Hilltop fault to its intersection with the Fulton fault. The pipe has a maximum diameter of 70 feet. Oxidized zinc minerals form a thick replacement casing of rich ore in the wallrock dolomite around the partly oxidized central part of the pipe, which in places is also rich in zinc carbonate but elsewhere is mostly galena and sphalerite. Smaller pipes and veins follow the Fulton and subsidiary faults. Behre (1953, p. 71, 152-156, pl. 1, fig. 56) gives many other details of the geology.

Smithsonite in irregular spongy masses having a gray or dull olivegreen color is the most common oxidized zinc mineral, but small quantities of aurichalcite, light-blue translucent reniform smithsonite, and chalky white smithsonite or hydrozincite are present also. The lead carbonate ores are rich in silver; and barite, quartz, siderite, and calcite are gangue minerals.

Oxidized zinc ore resources.-The known oxidized zinc ores are largely mined out, but Behre (written communication, 1958) thinks that a few thousand tons of commercial ore might be recovered from the district and from old waste piles.

References.-Behre (1953, p. 71, 152-156, pl. 1, fig. 71) ; Singewald and Butler (1941, especially pl. 1); Henderson (1926, p. 194).

\section{GUNNISON COUNTY}

\section{TOMYCHI (WHITE PINE) DISTRICT}

Plate 3, nos. 46, 49, 53, 54, 60, 64, 66, 74

Location.-The district is on the western slope of the Sawatch Range at White Pine in eastern Gunnison County, mostly in T. 49-50 N., R. 5 E. The district is accessible by good gravel road north from U.S. Route 50 at Sargents. The approximate outline of the district is shown on plate 3 .

Development and production.-Ore was first discovered in 1879, 3 miles north of White Pine near Tomichi Cemetery, which is at the site of the town of Tomichi (Crawford, 1913, p. 224). Crawford gives a history of the earlier mining, and Dings and Robinson (1957, p. 43-44) give information on mining and production in later years. Major production from the district ended in 1952 when the Akron mine closed.

Mining of oxidized zinc ores began in 1907 at the Morning Star mine, and the Victor mine first produced in 1909. Production of oxidized zinc and zinc-lead ores continued until about 1917, but the total 
production apparently was fairly small. The following mines either had produced oxidized ores by 1913 or had smithsonite or calamine on the dumps, according to Crawford (1913): Breadwinner, Denver City, David H., Annie Hudson, and Legal Tender.

Geology and ore.-The ore deposits vary considerably in metallic content, mineral assemblages, and in form and occurrence with respect to the lithology of wallrocks. In general, however, the deposits that are in Paleozoic sedimentary rocks are of the replacement type in limestone and dolomite, and it is this type that contains the oxidized zinc ores in places. Two rather distinct kinds of replacement ore bodies are represented. The most important one economically is replacement of limestone along fault zones; the other is blankets or pods along bedding. The ore near the surface in both types of ore bodies is strongly oxidized, but oxidation is shallow and commonly does not extend much below a depth of 100 feet. The geology has been described by Dings and Robinson (1957).

The oxidized zinc minerals are calamine and dirty white and gray smithsonite, and they are intimately associated with cerussite, limonite, jarosite, and copper carbonates. The oxidized ores, which directly replaced the sulfide ore bodies, contain 20 to 41 percent zinc and commonly much lead and silver. One such oxidized ore body, in the Victor mine, was estimated before mining to be as large as 40,000 tons. Much of the ore in the district was mined for its lead-silver content, and the zinc and copper were not recovered.

Oxidized zinc ore resources.-Small tonnages of oxidized zinc and zinc-lead-silver ores probably remain scattered in the shallow upper workings of many of the mines. Some of the dumps, such as the uppermost dump of the Morning Star mine, could be reworked. No large reserves are foreseen in the district because of the fairly shallow oxidation of the deposits.

References.-Dings and Robinson (1957), Crawford (1913).

\section{QUARTZ CRGHK DISTRICT}

Plate 1, nos. 51, 71; plate 3 , nos. 65,69

Location.-The district is in T. 50-51 N., R. 4 E., near Pitkin.

Remarks.-Smithsonite is a common constituent of the oxidized ores in Leadville Limestone at the Maid of Athens mine in the eastern part of the district; it has also been noted at the Silent Friend mine 2 miles to the south, where the ores are in Manitou Formation or Fremont Limestone. The ores are rich in silver, lead, and gold, and apparently are comparable with those of the Tincup district to the north. A small quantity of zinc (5,359 pounds prior to 1949$)$, most of which may have come from oxidized ores, has been recovered from 
the district (Dings and Robinson, 1957, p. 44). Oxidized zinc minerals are present, at least in small quantities, in the westernmost part of the district northwest of Pitkin at the Silver Islet mine and at prospects in Chicago Park.

\section{TINCUP DISTRICT}

Plate 3, nos. 47, 52, 56, 58, 61, 62, 67, 68, 70, 73, 73a

Location.-The small district is about 3 miles square and lies on the west slope of the Sawatch Range north of Cumberland Pass and south of Tincup, in T. 15 S., R. 81-82 W.

Development and production.-The first and most productive lode mine in the Tincup district was the Gold Cup discovered in 1878. Between 1878 and 1882 most of the larger deposits of the district were discovered, and Tincup, Hillerton, and Virginia City were established. The last two towns have vanished, but Tincup has had a few summer residents in recent years. The greatest period of activity was from 1882 to 1893 . Mining was revived in 1908-12, and it continued at intervals, mainly at the Gold Cup Republic mine and nearby gold placers.

Much of the oxidized ore is zinc rich, but the zinc has not been recovered from most of the ores produced. Perhaps 1,500,000 tons of such ore has been produced from the Gold Cup Republic alone, largely prior to 1883 . From 1901 through 1949 the district produced a recorded 4,133 tons of ore, mostly oxidized, from which 1,031 ounces of gold, 41,860 ounces of silver, 1,200 pounds of copper, 165,369 pounds of lead, and 9,520 pounds of zinc were recovered (Dings and Robinson, 1957, p. 44 ). The only mine reported to have produced oxidized zinc ores is the Napoleon mine, which A. L. Pearson, the owner, reported (oral communication, 1954) produced about 50 narrow-gauge carloads (approximately 900 to 1,000 tons). ${ }^{4}$ This ore, which was shipped to Coffeeville, Kansas, during World War I, apparently was not recorded by the U.S. Geological Survey and thus is in addition to the recorded district production given in Dings and Robinson (1957).

Geology and ore.-Most of the productive deposits are oxidized bedded replacement bodies of gold, silver, lead, copper, and zinc ores. The geology of these deposits has been described previously on pages C29-C30 and, in much greater detail, by Dings and Robinson (1957, p. 57-62).

Oxidized zinc ore resources.-The oxidized ore contained notable zinc. If the zinc had been recovered along with the other metals, the district would have been a substantial source, as perhaps 20,000

\footnotetext{
4 Published with permission of the property owner.
} 
to 50,000 tons of oxidized zinc-bearing ores rich in gold, silver, and lead has been produced in the past. This unusual type of ore-zinc-rich oxidized silver-lead-gold ore-has not been desired by smelters until recent years, and the nearest smelters in 1963 accepting such ores are in Utah or Texas.

Probably district reserves are not large but are high grade and are rich in precious metals. Several thousand tons very likely can be gleaned with ease from the district mines, dumps, and ore piles.

References.-Dings and Robinson (1957); Henderson (1926, p. 124-125) ; Goddard (1936).

\section{GOLD BRICK DISTRICT}

Plate 1, nos. 48, 50

Location.-The district lies in the central part of the Pitkin quadrangle north of Ohio (or Ohio City), in the drainage basins of Gold Creek and Alder Creek. The oxidized zinc deposits are restricted to the northwestern part of the district and are accessible only by trails in T. 51 N., R. 3 E.

Development and production.-Several small mines and prospects, including prospects southwest of Boulder Lake and the Carbonate King group at the head of the East Fork of Alder Creek, have oxidized zinc ores, but only the latter group has produced. In 1917, several narrow-gauge cars of hemimorphite zinc ores were produced, amounting to an estimated 60 to 100 tons of ore (U.S. Geol. Survey, 1917 , p. 823-824).

Geology and ore.-The oxidized zinc deposits are in an area of limestones, shales, and sandstones of Paleozoic age that form a prominent mountain ridge known as Fossil Ridge in the central part of the Pitkin quadrangle. The Carbonate King mine is in fractured limestone described as Leadville Limestone (Crawford and Worcester, 1916, pl. 2). In a drift 30 feet long at the bottom of the mine, veins of hemimorphite 1 to 12 inches thick were noted by Crawford (Crawford and Worcester, 1916, p. 110). The hemimorphite is in crystalline crusts and masses and is associated with some reniform light-colored smithsonite, a little cerussite, and some coarse calcite. An ore pile, containing a few tons of ore, at the mouth of the main incline was sampled and analyzed. The analysis data follow:

\begin{tabular}{|c|c|}
\hline Gold_-_-_--_- & None \\
\hline Silver_____-_ounces per ton_. & 4 \\
\hline Lead___-___-_percent__-_ & 0.90 \\
\hline Zinc_-_-_-_- & - 38.4 \\
\hline 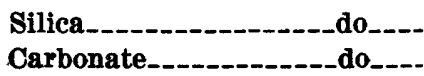 & 15. \\
\hline
\end{tabular}


This sample probably is fairly representative of the ore shipped.

Oxidized zinc ore resources.-Probably a small tonnage, at least, of ore similar to that shipped could be produced from the thin rich veins in the Carbonate King mine. Local mining men report little prospecting has been done in the area because of its inaccessibility and because the lead and zinc ores compare unfavorably with the rich gold-silver-lead veins in the main mines of the Gold Brick district. Other prospects, such as those near Boulder Lake, show oxidized lead and zinc minerals.

\section{TAYLOR PARK DISTRICT}

Plate 1, nos. 72, 75

Location.-The district includes most of the upper drainage basin of the Taylor River north of Taylor Park Reservoir, including the western slopes of the Sawatch Range and the Forest Hill-Italian Mountain area to the west. It is accessible by dirt roads and trails up the Taylor River from Almont and from Tincup.

Development and production.-Prospects and small- to mediumsized metal mines are scattered throughout the large district, which was first opened about 1875. All the known oxidized lead-zinc deposits lie near North Italian Mountain and to the north along the upper reaches of the Taylor River. As far as is known, there has been no production of oxidized zinc or zinc-lead ores, probably in part because the area is so inaccessible.

Geology and ore.-The known oxidized lead-zinc deposits are in the northern part of a band of limestones and other sedimentary rocks of Paleozoic age that extend from the Taylor River Reservoir northward to Ashcroft, north of Taylor Pass. One of the largest deposits, the Star mine, on the north flank of North Italian Mountain, is a silver-lead vein in limestone of the Leadville(?). Limestone that is oxidized to 140 feet. Most of the ore is reported to range between 5 to 20 percent lead as cerussite, 10 to 25 ounces of silver per ton, and 1 to 3 percent zinc as smithsonite. Locally, wallrock-replacement shells or pockets of smithsonite occur, but most of them are probably small.

Oxidized zinc ore resources.-No large oxidized zinc deposits are developed, but in places the limestone belt is strongly mineralized, by deposits very similar to those that contain large quantities of oxidized zinc ores at Spring Creek to the southwest and at Aspen to the north. Potentially, the belt seems very promising, especially as it has probably been much less prospected than many other areas because of poor access.

Reference.-Vanderwilt (1947, p. 101, 107). 


\section{SPRING CRFEK DISTRICT}

Plate 1, no. 55; plate 9

Location.-The Doctor Park area is along Spring Creek in the southwestern part of the Taylor Park area, T. 14 S., R. 83 W. Access is by good to very poor road up Spring Creek from Almont.

Development and production.- The main productive deposit in the district, that of the Doctor mine, was discovered about 1881 and was worked for about 10 years (Frank Hoheizel, oral communication, 1954). The mine was closed because the ore was too lean in silver to make the long and difficult haulage to smelters profitable. From 1914 to 1919 the mine was operated by Frank Hoheizel, who leased it from the Wick Mining Co. of Cleveland, Ohio. Mr. Hoheizel shipped large quantities of very rich oxidized zinc ores, and the Wick Mining Co. continued mining into 1920 after Hoheizel's lease expired. The mine was reopened and was operated in 1937 and 1938 for leadzinc ores, probably mostly from dumps and shallow workings. It was owned in 1954 by John Lambertson's son, of Taylor Park.

Accessible workings of the Doctor mine are shown on plate 4. The underground workings are reported to be extensive and to include large square-set stopes, now mostly caved (Hoheizel and Lambertson, oral communication, 1954).

Oxidized zine and lead-zinc ore production of the Doctor mine from 1914 through 1938 follows (table 9) :

TABLE 9.-Production of oxidized zinc ores from Doctor mine, 1914-38

[Data from Mineral Resources 1914-25, Minerals Yearbook 1925-38]

\begin{tabular}{|c|c|c|c|}
\hline Year & Ore (short tons) & $\begin{array}{c}\text { Recoverable lead } \\
\text { (pounds) }\end{array}$ & $\begin{array}{l}\text { Recoverable zinc } \\
\text { (pounds) }\end{array}$ \\
\hline $\begin{array}{l}1914 \\
1915 \\
1916 \\
1918 \\
1919 \\
1920 \\
1937\end{array}$ & $\begin{array}{l}\text { (1) } \\
22,500 \\
25,000 \\
25,000 \\
3,841 \\
4,170 \\
2,020 \\
548 \\
93\end{array}$ & $\begin{array}{r}25,000 \\
900\end{array}$ & $\begin{array}{r}21,400,000 \\
22,000,000 \\
23,000,000 \\
2,072,615 \\
2,321,849 \\
1,027,798 \\
174,000 \\
29,000\end{array}$ \\
\hline Total & ${ }^{3} 23,172$ & 25,900 & $\begin{array}{r}12,025,262 \\
(6,013 \text { tons })\end{array}$ \\
\hline
\end{tabular}

1 Small production of lead-silver ore. Mine leased to Frank Hoheizel, November 1914.

2 Estimated from published production data on district and Gunnison County. 35 percent zonc (oral communication, 1954).

Geology and ore.-The geology and ore body of the Doctor mine are shown on plate 4 and have been previously described (p. C28-C29).

Much of the oxidized zinc ore that remains contains some lead and 
is lean in silver, except locally. It would be classed as zinc-lead ore. Field examination indicates that the ore ranges in grade from 0 to 10 ounces of silver per ton, 0.5 to 6 percent lead, and 10 to 20 percent zinc. Most of the zinc is in smithsonite and hemimorphite.

Oxidized zinc ore resources.-According to Hoheizel (oral communication, 1954) when his lease expired in 1919, high-grade kidneyshaped masses of smithsonite similar to that shipped remained in the floor of the Doctor mine at a depth of 150 feet. A little mining was done afterward. He said that the body of rich ore, although still large, was constricted somewhat with depth. The dip of the quartzite beds underlying the limestones in which the ore body occurs is such that the ore may be cut off by quartzite at fairly shallow depths beneath the present workings. Large quantities of siliceous zinc-lead oxidized ore containing some silver remain unmined at the surface in this district and are reported by Hoheizel (oral communication, 1954) in the caved workings. They constitute a substantial resource for future use when economic conditions are favorable.

\section{ROCK CRHEK (MARBLE) DISTRICT}

Plate 1, nos. $47 a, 57,63$

Location.-The district is in the Elk Mountains east of Marble in the source area of the Crystal River of northern Gunnison County, in T. $11,12 \mathrm{~S} ., \mathrm{R} .87 \mathrm{~W}$. The mines are on the east and west flanks of Treasure Mountain and in Lead King Basin to the northeast (Vanderwilt, 1937, pl. 1).

Development and production.-The district is best known for its fine marble, which has been widely used throughout the country. Marble used in the Lincoln Memorial in Washington, D.C. is from this district. Many small metal mines are in the area, the largest of which is the Lead King mine. The deposits were found about 1876 and have produced sporadically since then. Oxidized zinc ores are not known to have been shipped from the district, although a few shipments of zinc ore in 1911 may have been oxidized ore.

Geology and ore.-Precambrian feldspar-biotite gneiss, the Paleozoic formations common to central Colorado, Jurassic and Cretaceous formations, and Tertiary intrusive rocks are exposed in a domal uplift. The ore deposits are confined to this structural dome and are most abundant on its northeast flank in a faulted and fissured zone 1-3 miles wide and 8 miles long (Vanderwilt, 1937). Zinc-lead ores are most abundant, although copper-silver and native silver ores have been produced. The deposits are oxidized locally, but elsewhere the oxidized parts have been removed by glacial erosion, and sulfides occur in the outcrops. Deposits reported to contain oxidized zinc ores are 
in limestones and dolomites of Ordovician age at the Eagle Lead Bullet, in veins in hornfels of the Maroon and Morrison Formations at the Bon Ton, and in limestone of Niobara age (Late Cretaceous) in the Mancos shale at the Lead King mine. All the deposits are small, and the oxidized ores replace the sulfides directly.

Oxidized zinc ore resources.-At most, only a small tonnage of oxidized and mixed sulfide-oxidized ores can be expected from this district, although the area has not been as thoroughly prospected as have many others in Colorado; so other deposits may be found. Vanderwilt (1937) points out that prospecting has been concentrated on the veins, which are small, rather than on the bedded replacement deposits, which have produced the most ore. The general Elk Mountain area is especially worthy of further search for new deposits, both sulfide and oxidized.

\section{ChAFFEe COUNTY}

\section{MONARCH DISTRICT}

Plate 1, no. 78a ; plate 3 , nos. 76, 77, 79, 81-88, 90-94, 96-100, 102, 103

Location.-The Monarch-Tomichi-Tincup area is shown on plate 1, and the Monarch district is shown on plate 3. The deposits containing oxidized-zinc ores fall into two main groups: (1) the Monarch group. clustered on Monarch Ridge east and south of Monarch, and (2) the Garfield group north of Garfield in Taylor Gulch and Cree Creek.

Development and production.--The district was prospected for placer gold as early as 1860, but the first lode deposits, including the Madonna and Great Monarch mines, were discovered about 1878 . Prior to 1901, lead-silver-gold ore with an estimated value of $\$ 9$ million was produced from the district; and since that time, leadsilver-gold-zinc-copper ore with an estimated value of $\$+, 195,000$ has been produced (Dings and Robinson, 1957, p. 44). Almost 50 percent of the total came from the Madonna mine.

According to J. B. McDonald (oral communication to G. F. Loughlin, pre-1918, in Loughlin, 1918, p. 12), oxidized zinc ores were first produced from the Madonna, Eclipse, and Monarch Pool mines in 1902 ; and further shipments were made in 1903, 1905, and 1906. Production records begin in 1906, when a substantial tonnage of oxidized zinc ore averaging 34 percent zinc was produced. Oxidized zinc and zinc-lead ores were produced from the Madonna mine every year from 1906 through 1922, and small shipments were made in 1926 and 1930. The total production from this mine alone is estimated from incomplete published data to be about 25,000 tons of oxidized zincbearing ores that ranged in grade from 18 to 34 percent zinc. The next largest production came from the Eclipse mine, where from 1901 to $1926,4,925$ tons of ore, nearly all oxidized, yielded 86 ounces of 
gold, 6,577 ounces of silver, 17,510 pounds of copper, 222,271 pounds of lead, and 2,002,367 pounds of zinc (Dings and Robinson, 1957, p. 87).

The district's production of oxidized zinc and lead-zinc ores is the second largest in Colorado. Incomplete published production data suggest that between 30,000 and 35,000 tons of such ores has been produced to 1963. Mines known to be productive between 1902 and 1949 are the Alaska, Eclipse, Fairplay, Flossie D, Garfield, Great Monarch, Hawkeye, Lilly, Little Claim, Little Giant, Madonna, Monarch Pool, New York, Paymaster, Silent Friend, and Wilson mines. The most active periods of production were apparently 1906-10 and 1914-17.

Geology and ore.-The district includes large areas of Precambrian schist and gneiss intruded by several granites and diorites of the same age. Sedimentary rocks of Paleozoic age occur in several areas as remnants of eroded synclines or down-faulted blocks, and some are partly or completely surrounded by younger intrusive bodies. The Paleozoic formations comprise Sawatch Quartzite (Upper Cambrian), Manitou Formation (Lower Ordovician), Harding Quartzite (Middle Ordovician), Fremont Limestone (Middle and Upper Ordovician), the Chaffee Formation (Upper Devonian), Leadville Limestone (Mississippian), Belden Shale (Pennsylvanian), and the Minturn Formation (Pennsylvanian and probably Permian). The Paleozoic strata older than Pennsylvanian are less than 1,000 feet thick. A great succession of intrusive rocks-mostly quartz monzonite, probably of early Tertiary age-form chonoliths, stocks, sills, and dikes. Dings and Robinson (1957) present a comprehensive geologic description of the district (except its easternmost part) and the areas surrounding it to the north. A fine older report by $R$. D. Crawford (1913) includes the easternmost part.

The ore deposits containing oxidized zinc ores are replacement deposits in limestones and dolomite of Paleozoic age, and the structure and stratigraphy have been instrumental in localizing ore bodies. Manitou Formation and beds in the upper part of the Leadville Limestone are especially favorable rocks. The largest and richest replacement deposits are in these stratigraphic zones along premineral faults; but small faults, particularly bedding slips along favorable zones, localized many of the smaller ore bodies. Ore shoots in the larger bodies follow faults and vary from veinlike to blanket and pipelike bodies in favorable beds along the faults.

The chief primary sulfide minerals are silver-bearing galena, goldbearing pyrite, sphalerite, and chalcopyrite. These minerals, especially in the Madonna and adjacent mines, are oxidized to a variety of 
minerals, such as cerussite, smithsonite, gold, silver, cerargyrite, hemimorphite, anglesite, native sulfur, minium (?), plumbojarosite, leadantimony ochers, chalcocite, covellite, limonite, melaconite, wulfenite, pyrolusite, chalcophanite(?), malachite, azurite, and a little hydrozincite.

The main ore bodies of the Madonna mine (pl. 3, no. 94) are the largest in the district. They consist of large irregular replacements of the Manitou and Fremont Formations. The main ore bodies plunge northward down the dip of the beds along the Madonna fault (pl. 6), and they have many northward-plunging branches (fig. 7A) in breccia zones and beds replaced by ore along the fault. Locally the lower parts of the ore bodies pinch into veins, as shown in the left section of figure $7 B$. Nearly all the ore in the deeper northern part of the mine is in veins and massive sulfide bodies, local parts of which are oxidized. The nearby Eclipse mine is in similar but smaller ore bodies along the Mayflower fault, southeast of the area shown on plate 6. The Hawkeye mine lies just west of the Madonna in a series of similar ore bodies near the Hawkeye fault.

Oxidized zinc ores are abundant in these deposits and in similar ones nearby. They occur in several parts of the Madonna mine: (a) intermixed with the lead-silver-gold ores, especially in the main ore bodies above Level 5 (pl. 6 ; fig. 7 ), but also below; (b) as hemimorphite and smithsonite envelopes around the silver-lead ore bodies; and (c) in the bottom part of limonitic silver-lead ore that forms marginal and footwall replacements of primary ore and limestone wallrocks. Hemimorphite is the most common mineral in the upper levels (levels 0,1 , and 2), and smithsonite is more common on levels 3 and 4 . Hemimorphite is also the most abundant mineral in the large zinc ore bodies in the basal parts of limonitic bodies in the Madonna (fig. 7) and in the deeper veins of this mine, in the Eclipse, and probably in the Silent Friend (judging from the material on the upper dumps). Many of the ore bodies on Monarch Ridge and in the Garfield area-such as the Wilson, Lilly, and Garfield mines - are similar geologically to the Madonna mine. In a few, such as in the partly stoped Iron vein in the Lower New York Tunnel (pl. 3, no. 98), smithsonite ore directly replaces dark-brown sphalerite, and similar deposits occur north of the New York mine at the source of Cree Creek.

Partial analyses showing the range in composition of oxidized zinc ores from the Monarch district follow in table 10.

Although most of the ore is not notably rich in precious metals, the first analysis of ore mined many years ago shows that some was rich in silver, probably as cerargyrite. 


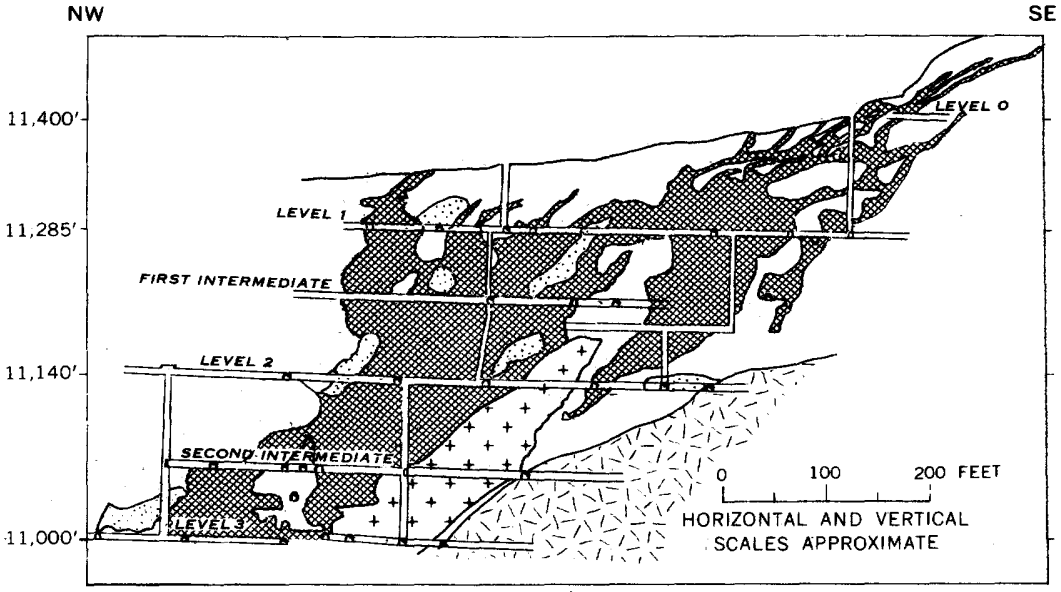

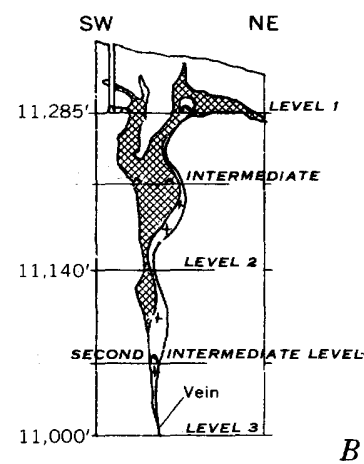

Sections by R. D. Crawford (1913,p| 23)

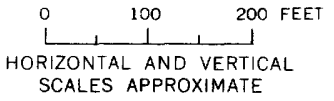

$A$

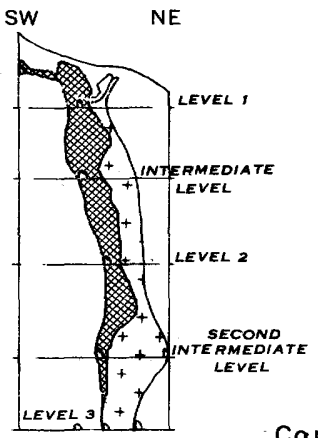

Commercial lead, silver, gold ore bodies

Oxidized zinc minerals intermingled and in casings near margins and bottom of ore bodies

$$
\leftarrow \pm
$$

Limonite iron ore

Marginal footwall replacements of primary ore and limestone wallrocks; contains some silver and a little lead; hemimorphite ore lies in basal parts of limonitic bodies

\section{Mine workings}

Levels, shafts and winzes in and near line of section

Drifts crossing plane of sections

FIGURE 7.-Diagrammatic sections through oxidized zinc-bearing main ore bodies of the Madonna mine, Monarch, Colo. A, Longltudinal section through upper part of main ore zone above level $3 ; B$, sections across central part of main ore bodies above level 3. 
TABLE 10.-Range in composition of the oxidized zinc ores, Monarch district, Colorado

[nd, not determined]

\begin{tabular}{|c|c|c|c|c|}
\hline & 1 & 2 & $\mathbf{3}$ & 4 \\
\hline Gold _......... ounces per ton & & Trace & 0.015 & None \\
\hline Silver & 130. 75 & 1.80 & 1. 60 & 1.60 \\
\hline Lead. & 10.75 & 8. 00 & 5. 60 & .80 \\
\hline Zinc $\ldots \ldots$ do & 39.95 & 37.8 & 30.1 & 22.1 \\
\hline Silica__._._. & nd & 18.2 & 10.4 & 34.6 \\
\hline Iron & nd & 6. 4 & 18. 6 & nd \\
\hline Carbonate. & nd & 17. 6 & 22.2 & 18.5 \\
\hline Manganese & nd & nd & 9.42 & nd \\
\hline
\end{tabular}

1. Carload of ore (about 20 tons) from Fairplay mine (Craw ford, 1913, p. 200): analyst not known, probably smelter returns.

2. Representative sample from ore bin, Eclipse 2 level: analyst: Deason and Nichols, Salt Lake City. 1954.

3. Grab sample from Hawkeye 3 dump: probably a mixture of hemimorphite, smithsonite, pyrolusite, chalcophanite, and earthy manganese oxide: analyst: Deason and Nichols, Salt Lake City, 1954.

4. Five-foot ehannel sample across Iron Vein, southwest stopes of Lower New York Tunnel; analyst: Deason and Nichols, Salt Lake City, 1954.

Oxidized zinc ore resources.--Large dumps rich in zinc remain in the Monarch district. Some of the upper dumps are rich enough in metal to constitute shipping ore. For example, nearly 25,000 tons of inferred ore is estimated to remain on the Eclipse, Madonna, Hawkeye, and Silent Friend 3 dumps. ${ }^{5}$ Preliminary sampling suggests that much of this dump ore contains as much as 20 percent zinc and lead plus a little silver, copper, and gold.

Reserves in the mines are much less certain but may be substantial. For example, in 1920 the Giant-Eclipse Consolidated Mines Co. claimed to have "developed" a reserve of 10,000 tons of low-grade oxidized zinc ore (Weed, 1920, p. 531). Only a small tonnage of ore was produced after this date; so, if the claim is correct, most of the ore remains. In 1931 the company repeated this estimate in the Mines Handbook (Weed, 1931, p. 548) and gave the average grade as 0.017 ounces of gold and 1.3 ounces of silver per ton, 2.2 percent lead, and 20.3 percent zinc. Ore of better grade remains in the upper Eclipse mine bin (see analysis, table 10).

The reserves at the Madonna mine are known with much less certainty because the workings above level 4 were mined and caved early in the history of the mine and were inaccessible as early as 1911 (Crawford, 1913). Most of the oxidized zinc ore produced came from below level 3, but oxidized zinc ores are more abundant on the dumps from the uppermost workings. Little mining was done after 1915 from the upper workings above level 3. Much oxidized ore may be lost because the rich upper stopes are caved, but some and possibly a substantial quantity of good ore might be recovered. The richest

5 Published with permission of the property owner. 
ore is probably similar to that in the Madonna level 0 bin, an analysis of which is given in table 5 .

Some oxidized ore remains in the Iron Vein of the Lower New York Tunnel, in the Lilly mine, and possibly in many other mines in the district. Some mines have been destroyed by the large-scale limestone quarrying operations of the Colorado Fuel and Iron Co. at Monarch.

CHALK CREEK (ROMLEY) DISTRICT

Plate 3, nos. 78, 89, 95

Location.-The district is in the vicinity of St. Elmo in the upper part of the Chalk Creek valley. Mines reported to contain oxidized zinc ores lie near the crest of Crysolite Mountain 3 miles south of St. Elmo, Chaffee County (pl. 3).

Remarks.-Oxidized zinc ores were reported in the upper oxidized parts of the Mary Murphy and Iron Chest mines and at the Blackhawke mine north of them on the same vein system. Field examination failed to reveal any oxidized zinc ores except a few hand samples, although a siliceous sinter carrying gold and a little silver was found that closely resembled smithsonite.

\section{COTTONWOOD CREEK DISTRICT}

Plate 1, no. 80

Location.-This district is along the upper reaches of Cottonwood Creek on the east slope of the Sawatch Range in T. 14-15 S., R. 80-81 W. Two prospect shafts of several in the southern part of the district are shown on plate 3 . The mines are accessible by dirt roads and trails from Buena Vista.

Remarks.-This small silver-lead district is not known to have produced any oxidized zinc ore. Most of the rocks are schists of Precambrian age and intrusive Mount Princeton Quartz Monzonite of Tertiary age. Locally within the district are small synclinal areas of limestones and dolomite of Paleozoic age similar to those in the Monarch district farther south. The largest of these areas is shown on plate 1 and contains bedded replacement deposits of silver-leadzinc ores, in part oxidized. C. S. Robinson (oral communication, 1955) noted a few tons of oxidized lead and zinc ores on some of the dumps during his geologic study in the Garfield quadrangle (Dings and Robinson, 1957). No other reserves are known, but the district may be worthy of a more thorough examination to see if deposits of commercial value exist.

References.-Dings and Robinson (1957, pl. 1) ; Vanderwilt (1947, p. 45). 


\section{SEDALIA MINE}

Plate 1, no. 101

Location.-The mine is commonly included in the Turret coppergold district, but actually it is a distinct mining area about 4 miles north-northwest of Salida on the lower eastern slope of the Arkansas River valley in the NW1/4 sec. 18, T. 50 N., R. 9 E. It is visible from Colorado Route 291 and is accessible by a rough road eastward from this highway at Belleview.

History and production.-The Sedalia deposit was found about 1883 and was worked at intervals for many years, at least through World War I. It produced about 400 tons per month of copper-zinc ores, probably oxidized, in 1906-07 (Lindgren, 1908, p. 161-162); the ore was shipped to the Canon City zinc-lead paint plant, where the zinc was used for paint and the residues were smelted for copper matte. Company information obtained by Lindgren indicated that at that time between 60,000 and 75,000 tons of copper-zinc ore, mostly oxidized, had been shipped from the mine, and that the ore contained at least 5 percent copper, nearly twice as much zinc, and from $\$ 1$ to $\$ 2.50$ worth of gold and silver per ton. Later, in 1912, oxidized zinc ores were shipped (U.S. Geol. Survey, 1912). The total production of the mine is estimated from the size of the workings to have been nearly 100,000 tons of ore; some was sulfide ore, and some was only partly oxidized.

Geology and ore.-The Sedalia copper-zinc-lead deposit is in noncarbonate rocks of Precambrian age. The geology has been described (p. C31-C32, C42-C44), and an analysis of the unusual sulfate-bearing oxidized ore has been given ( $p$. C31).

Oxidized zinc ore resources.-Ore similar to that produced remains in the mine, in addition to a substantial quantity of lower grade material. Some of the ore is sulfide, some is oxidized, and a fairly large quantity is a mixture of the two. The partly oxidized copperzinc ore containing some gold, silver, and lead is difficult to market at present-day copper or zinc smelters because the abundant zinc is detrimental to copper smelting and the abundant copper and incomplete oxidation of the zinc minerals is detrimental to zinc smelting.

\section{FREMONT COUNTY}

\section{COTOPAXI DISTRICT}

Plate 1, no. 103a

Remarks.-The Cotopaxi mine is about one-half mile northwest of Cotopaxi, Colo., in a massive sulfide deposit in rocks of Precambrian age similar to that of the Sedalia mine. Gahnite, the zinc spinel, is a 
common mineral closely associated with the sulfides, but it was never mined commercially. The geology of the deposit was described by Lindgren (1908, p. 166-167).

\section{CUSTER COUNTY}

\section{SILVER CLIFF, ILSE, AND ROSITA DISTRICTS}

Plate 1, nos. 105, 105a, 104, respectively

Location.-The Silver Cliff district is centered on the White Hills, lying just north of the towns of Westcliffe and Silver Cliff. The Defender mine is in the central part of these hills, and the Bull Domingo mine is north of the White Hills. The Rosita district lies about 8 miles east of Silver Cliff. The Bassick mine is the best known property and lies in the semighost community of Querida about 2 miles north of Rosita. The Terrible mine is at Ilse, about 13 miles by road northeast of Rosita.

Development and production.-These districts were major silvergold- and lead-mining areas between 1875 and 1885, but activity has gradually declined since then. Small quantities of zinc have been produced, most of it probably from sulfide ores.

Geology and ore.-The districts have a variety of silver veins, lodes, and breccia-pipe deposits in Precambrian gneisses and in felsic volcanic rocks of Tertiary age. Several types of deposits contain oxidized zinc minerals in quantities approaching commercial value. For example, the vein in rhyolite in the. Defender mine is oxidized to a depth of 75 feet. Zinc carbonate is locally concentrated with lead carbonate ore, particularly in the upper parts of the western stopes. About 2 miles to the north, the famous Bull Domingo mine is a breccia-pipe silver deposit of Tertiary age cutting gneiss of Precambrian age (Emmons, 1896). Crusts of white crystalline smithsonite were noted here in the breccia cavities. Similar smithsonite is reported by Emmons in the upper levels of the Bassick mine, which worked a breccia pipe in volcanics of Tertiary age. The occurrence of zinc carbonate as a minor constituent of the lead carbonate lodes at Ilse has already been mentioned (p. C22).

Oxidized zinc ore resources.-None are known with certainty, but a few of the deposits might have a small quantity of lead-zinc ores.

\section{SAN MIGUHL COUNTY}

\section{PLACER VILLE DISTRICT}

Plate 1, no. 106

Location.-The district is centered at Sawpit along the San Miguel River. 
Remarks.-The Belle Champion gold-silver mine, just north of Sawpit on the San Miguel River near Placerville, has small quantities of smithsonite locally in its deeply oxidized ores. No commercial quantities are known.

\section{DOLORES COUNTY}

\section{RICO DISTRICT}

Plate 1, nos. 107-110

Location.-The district is in the western San Juan Mountains in eastern Dolores County, near the town of Rico. The largest deposits are in the hills just east of Rico.

Development and production.-The Rico district is one of the larger and more productive silver-lead-copper-zinc districts in the western San Juan Mountains. Production of base metals and of pyrite for sulfuric acid has continued on a fairly large scale until at least 1963. No oxidized zinc ores are known to have been produced, though they are present in the district.

Geology and ore.-Ore deposits at Rico are replacement blankets in thin limestone units interbedded with clastic rocks in the middle part of the Hermosa Formation of Pennsylvanian age (Ransome, 1901, p. 259). Oxidized zinc ores occur at the outer margins of oxidized parts of the deposits near the surface or near outcrop areas. Most of the oxidized zinc-lead ores found during field study are a mixture of cerussite, smithsonite, some hydrozincite, and some unleached galena. Aurichalcite is a rare associated mineral. Such ore is most common in the old upper workings on Nigger Baby Hill just east. of Rico. Much of this zinc-rich ore was thrown on the dumps, probably to avoid smelter penalties. A partial analysis of a random sample of oxidized zinc-lead ore from the dumps is given below.

Partial analysis of random dump sample, Rico district

[Analyst, Deason and Nichols, Salt Lake City, Utah, 1954]

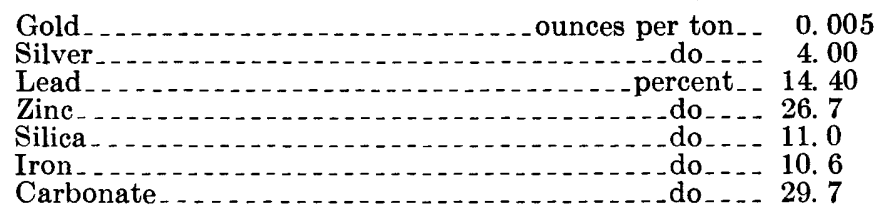

Some of the oxidized zinc minerals are mixed with lead and silver minerals and probably directly replaced the primary ores. Quite a lot of the oxidized zinc ore was fairly pure smithsonite and hydrozincite which occurred as wallrock replacement casings or pockets at the margins of, or beneath, the blanket deposits. 
Oxidized zinc ore resources.-Most of the old shallow workings in oxidized ore are caved and inaccessible, but the quantity of oxidized zinc and zinc-lead ores in the accessible workings and on the mine dumps, especially on Nigger Baby Hill, suggests strongly that com. mercial quantities of such ores remain unmined (and unrecognized by the miners) in the district.

References.-Ransome (1901, p. 229-397); Cross and Spencer (1900, pt. 2, p. 7-165); Cross and Ransome (1905).

\section{SAN JUAN COUNTY}

RED MOUNTAIN AND NEEDLE MOUNTAIN DISTRICTS

Plate 1, nos. 111, 111a, respectively

Location.-The districts are on Red Mountain and on Needle Mountain, both near Silverton.

Remarks.-As far as is known, oxidized zinc ores are uncommon in the central part of the San Juan Mountains. Smithsonite occurs as a minor constituent in the lead carbonate pipes at the Lark mine in the southern Red Mountain district, but nearly everywhere else in the district oxidation is very shallow, extending only a few feet in depth (Wilbur Burbank, oral communication, 1954). At the Mary Holbrook mine in the Needle Mountain district a small body of partly oxidized zinc-copper ore is reported to have about the same metal content and ratio as that of the Sedalia deposit, but nothing is known of the geology.

\section{MINERAL COUNTY}

\section{SUNNYSIDE DISTRICT}

Plate 1, nos. 112, 116-117

Location.-The district is at the site of Sunnyside about 2 miles west of Creede in sec. 35, T. 42 N., R. $1 \mathrm{~W}$.

Development and production.-This silver-lead district is satellitic to the main Creede district. Most of the Sunnyside district has long been idle. The district has produced silver-lead ores but no oxidized zinc ore.

Geology.-The deposits are at the south end of the Alpha-Corsair fissure zone, which trends northwestward, cutting rhyolites and volcanic breccia. The Silver Hoard mine is the southernmost deposit; it is on the southwest side of a hill of travertine and other hot-spring deposits of Quaternary age and volcanic breccia of Tertiary age that lie on the north rim of the Creede Caldera (T. A. Steven, oral communication, 1955). Calamine replaces the most leached parts of the travertine as clear acicular crystals associated with limonite and iron sulfate. Analysis of material from the dumps of the Magnusun 
Tunnel, in a nearby and geologically similar deposit, show about 5 percent zinc and 1 percent lead. Similar zincy material was seen at the Alpha mine a short distance to the west across Rat Creek valley. Oxidized zinc resources.-Some very lean zinc-bearing material is present, but no commercial ore.

References.-Emmons and Larsen (1913, 1923); Larsen (1929).

\section{CREEDE DISTRICT}

Plate 1, nos. 113, 115

Location.-Most of the district is north of Creede along the branches of Willow Creek. The largest and best known properties are the Amethyst-Happy Thought and the King Solomon-Holy Moses mines.

Development and production.-The Creede district is famous for its very rich silver-gold-lead-zinc deposits. More than 10,000 tons of metallic zinc was produced from the sulfide ores prior to 1908 . By 1911, silver, gold, lead, and zinc totalling $\$ 37$ million had been produced, and several million dollars' worth of ore has been produced since then. Most of the ore came from the Amethyst vein. No oxidized zinc or zinc-lead ore is known to have been shipped, but such zinc-rich ores have been left unmined in the stopes.

Geology and ore.-The geology of the district and its ore have been described in an earlier part of the report (see p. C24-C25).

Oxidized zinc resources.-According to miners in the district, about 5 percent of the ore in the district contains enough zinc to result in penalties at the lead smelters. Large quantities of such ore coated with goslarite and zinc sulfate were seen in some of the old stopes, where it is a substantial potential resource of zinc-lead-silver ore that could be mined.

References.-Emmons and Larsen $(1913,1923)$.

SPAR DISTRICT

Plate 1, no. 114

Remarks.-The district lies on the southwest side of the Creede Caldera about 20 miles by road southwest of Creede. The Bird Creek mine, which was one of several, worked a vertical fissure vein several feet wide in felsic volcanic rocks containing coarse white platy barite, a little steel galena, and sparse patches of coarse honey-yellow sphalerite. Near the surface, where the vein is oxidized, the sphalerite is partly or completely replaced by brown smithsonite and hemimorphite, and the galena by cerussite. Large quantities of such material, all low grade, occur here, but no commercial ore. 


\section{COSTILLA COUNTY}

Remarks.-A single shipment of zinc-lead ore, probably oxidized, was made from the Jaroso area about 1941; nothing more is known. The Russell (Grayback) district (pl. 1, no. 118) has produced since 1929. Here Vanderwilt (1947, p. 64-65) reports lean gold mineralization in veins in sandstone and limestone of Carboniferous age intruded by monzonite and diorite. Jaroso, however, is a long way from Russell and not a very likely shipping point for ores from this district; so the ores shipped from Jaroso may have come from somewhere else.

\section{SELECTED REFERENCES}

Ames, E. W.. 1946, Exploration of the Jewell Tunnel zinc property, Chaffee County, Colorado: C.S. Bur. Mines Rept. Inv. 3933, p. 4, figs. 2, 3.

Argall, G. O., 1911, Oxidized zinc ores at Leadville: Eng. Mining Jour., v. 90, no. 8 , p. 399.

Argall, Phillip, 1914, The zinc carbonate ores at Leadville : Mining Mag. [London] v. 10, p. 282-288.

Bass, N. W., and Northrop, S. A., 1963, Geology of Glenwood Springs quadrangle and vicinity, northwestern Colorado: C.S. Geol. Survey Bull. 1142-J, p. J1-J74.

Behre. C. H., Jr., 1932, The Weston Pass mining district, Lake and Park Counties, Colorado: Colorado Sci. Soc. Proc., v. 13, p. 53-75.

1953, Geology and ore deposits of the west slope of the Mosquito Range: C.S. Geol. Survey Prof. Paper 235, 173 p.

Bishop. O. M., and Miller, E. B., 1956, Zinc industry in 1954: U.S. Bur. Mines Mining Market Repts. Mus 2477, p. $2,4$.

Butler, G. M., 1913, Some recent developments at Leadville; Second paper, The oxidized zinc ores : Econ. Geology, v. 8, no. 1, p. 1-18.

Clarke, F. W., 1915, Analyses of rocks and minerals from the laboratory of the C.S. Geological Survey, 1880 to 1914 : L.S. Geol. Survey Bull. 591, 376 p.

Crawford, R. D., 1913, Geology and ore deposits of the Monarch and Tomichi districts, Colorado: Colorado Geo. Survey Bull. 4, $317 \mathrm{p}$.

Crawford, R. D., and Gibson, Russell, 1925, Geology and ore deposits of the Red Cliff district: Colorado Geol. Survey Bull. 30, $89 \mathrm{p}$.

Crawford, R. D., and Worcester, P. G., 1916, Geology and ore deposits of the Gold Brick district, Colorado: Colorado Geol. Survey Bull. 10, $116 \mathrm{p}$.

Cross, Whitman, and Ransome, F. L., 1905, Description of the Rico quadrangle: C.S. Geol. Survey Geol. Atlas Rico folio (no. 130), 20 p.

Cross, Whitman, and Spencer, A. C., 1900, Geology of the Rico Mountains, Colorado: C.S. Geol. Survey 21st Ann. Rept. pt. 2, p. 7-16\%.

Dings, M. G., and Robinson, C. S., 19:57, Geology and ore deposits of the Garfield quadrangle, Colorado: C.S. Geol. Survey Prof. Paper 289, 110 p.

Eckel, E. B., 1961, Minerals of Colorado--A 100-year record: C.S. Geol. Survey Bull. 1114,399 p.

Emmons, S. F., 1886, Geology and mining industry of Leadville, Colo.: U.S. Geol. Survey Mon. 12, p. 376, 389, 398, 547, 550, 556, 557, 560.

1896, The mines of Custer County, Colorado : C.S. Geol. Survey Ann. Rept. 17, pt. 2, p. 40:-472. 
Emmons, S. F., and Irving, J. D., 1907, The Downtown district of Leadville, Colo.: U.S. Geol. Survey Bull. 320, p. 32-33.

Emmons, S. F., Irving, J. D., and Loughlin, G. F., 1927, Geology and ore deposits of the Leadville mining district, Colorado: U.S. Geol. Survey Prof. Paper 148, 368 p.

Emmons, W. H., 1917, The enrichment of ore deposits : U.S. Geol. Survey Bull. $625,530 \mathrm{p}$.

Emmons, W. H., and Larsen, E. S., 1913, A preliminary report on the geology and ore deposits of Creede, Colo.: U.S. Geol. Survey Bull. 530, p. 42-65.

1923, Geology and ore deposits of the Creede district, Colorado: U.S. Geol. Survey Bull. 718, 198 p., 12 pls.

Gale, H. S., 1906, The Hahns Peak gold field, Colo. : U.S. Geol. Survey Bull. 285, p. 28-34.

George, R. D., and Crawford, R. D., 1908, The Hahns Peak region, Routt County, Colorado: Colorado Geol. Survey 1st Rept., p. 189-229.

Goddard, E. N., 1936, The geology and ore deposits of the Tincup mining district. Gunnison County, Colorado : Colorado Sei. Soc. Proc., v. 13, no. 10, p. 551-595.

Gould, D. B., 1935, Stratigraphy and structure of Pennsylvanian and Permian rocks in Salt Creek Area, Mosquito Range, Colorado: Am. Assoc. Petroleum Geologists Bull., v. 19, no. 7, p. 971-1009.

Hazen, S. W., Jr., 1956, Exploration for lead and zinc at the Madonna mine, Monarch mining district, Chaffee County, Colo.: U.S. Bur. Mines Rept. Inv. 5218, 26 p.

Henderson, C. W., 1926, Mining in Colorado: U.S. Geol. Survey Prof. Paper 138, $263 \mathrm{p}$.

Hewett, D. F., and Fleischer, Michael, 1960, Deposits of the manganese oxides: Econ. Geology, v. 55, no. 1, pt. 1, p. 8, 12-13.

Heyl, A. V., 1963, Oxidized zinc deposits the United States, Part 2 Utah: U.S. Geol. Survey Bull. 1135-B, p. B1-B102.

Heyl, A. V.. Jr., and Bozion, C. N., 1960, Varieties of supergene zinc deposits in the United States, in Short papers in the geological sciences: U.S. Geol. Survey Prof. Paper 400-B, p. B2-B5.

Heyl, A. V., and Bozion, C. N., 1964, Oxidized zinc deposits of Nevada and California : U.S. Geol. Survey Mineral Inv. Resource Map MR-39. (In press.)

1962, Oxidized zinc deposits of the United States, Part 1, General Geology : U.S. Geol. Survey Bull. 1135-A, p. A1-A52.

Hodges, J. L., 1901, Agent for Colorado, in Roberts, G. E., Report of the Director of the Mint upon the production of the precious metals in the United States during the calendar year 1900 : U.S. Bur. Mint Rept. for 1901, p. 128-131. 1902, Agent for Colorado, in Roberts, G. E., Report of the Director of the Mint upon the production of the precious metals in the United States during the calendar year 1901; U.S. Bur. Mint Rept. for 1902, p. 130-134, 136-139.

Hunter, J. F., 1914, Some cerussite deposits in Custer County, Colo. : U.S. Geol. Survey Bull. 580, p. 25-37.

Koschmann, A. H., 1947, Kokomo (Tenmile) mining district, Summit County, in Vanderwilt, Mineral Resources of Colorado : Denver, Colo., Colorado Mineral Resources Board, p. 370-378.

Koschmann, A. H., and Wells, F. C., 1946, Preliminary report on Kokomo mining district, Colorado: Colorado Sci. Soc. Proc., v. 15, no. 2, p. 51-112.

Larsen, E. S., 1929, Recent mining developments in the Creede district, Colo: U.S. Geol. Survey Bull. 811, p. 89-112. 
Lindgren, Waldemar, 1908, notes on the copper deposits in Chaffee, Fremont, and Jefferson Counties, Colo.: U.S. Geol. Survey Bull. 340, p. 161-169.

1933, Mineral deposits: New York and London, McGraw-Hill Book Co., p. 803.

Loughlin, G. F., 1918, The oxidized zinc ores of Leadville, Colorado: U.S. Geol. Survey Bull. 681, 89 p.

1919, Zinc carbonate and related ores at Ophir, Utah: U.S. Geol. Survey Bull. 690, 14 p.

1926, Guides to ore in the Leadville district, Colorado: U.S. Geol. Survey Bull. 779, $37 \mathrm{p}$.

Lovering, T. S., 1934, Geology and ore deposits of the Breckenridge mining district, Colorado: U.S. Geol. Survey Prof. Paper 176, 64 p.

Lovering, T. S., and Goddard, E. N., 1950, Geology and ore deposits of the Front Range, Colorado: U.S. Geol. Survey Prof. Paper 223, 313 p.

Lovering, T. S., and Tweto, O. L. 1947, The Gilman district, Eagle County, in Vanderwilt, J. W., Mineral Resources of Colorado: Denver, Colo., Colorado Mineral Resources Board, p. 378-387.

Ohle, E. L., 1959, Some considerations in determining the origins of ore deposits of the Mississippi Valley type : Econ. Geology, v. 54, p. 769-789.

Palache, Charles, and others, 1957, The system of mineralogy of James Dwight Dana and Edward Salisbury Dana, Yale University, 1837-1892 : New York, John Wiley \& Sons, v. 2, p. 178-179.

Patton, H. B., Hoskin, A. J., Butler, G. M., 1912, Geology and ore deposits of the Alma district, Park County, Colorado: Colorado Geol. Survey Bull. 3, $272 \mathrm{p}$.

Penfield, S. L., 1894, Contributions to the crystallization of willemite: Am. Jour. Sci., 3d ser., v. 47, p. 305-309.

Pough, F. H., 1941, The occurrence of willemite: Am. Mineralogist, v. 26, no. 2, p. 92-102.

Ransome, F. L., 1901, The ore deposits of the Rico Mountains, Colorado: U.S. Geol. Survey 22d Ann. Rept., pt. 2, p. 229-397.

1911, Geology and ore deposits of the Breckenridge district, Colorado: U.S. Geol. Survey Prof. Paper 75, 185 p.

Rey, M., Sitia, G., Raffinot, P., Formanek, V., 1954 Flotation of oxidized zinc ores : Mining Eng., v. 6, no. 4, p. 416-420.

Rohlfing, D. P., 1938, The Colorado mineral belt and the Aspen mining district, Pitkin County; Colorado: Colorado Mining Assoc. Mining Year Book 1937, v. 25, p. 16-17, 62-64, 90.

Ross, C. S., 1946, Sauconite, a clay mineral of the montmorillonite group: Am. Mineralogist, v. 31, nos. 9-10, p. 411-424.

Singewald, Q. D., and Butler, B. S., 1931, Preliminary report on the geology of Mt. Lincoln and the Russia mine, Park County, Colorado: Colorado Sci. Soc. Proc., v. 12, p. $389-406$.

1933, Suggestions for prospecting in the Alma district, Colorado: Colorado Sci. Soc. Proc., v. 13, no. 4, p. 110-114.

1941, Ore deposits in the vicinity of the London fault of Colorado: U.S. Geol. Survey Bull. 911, 74 p.

Smirnow, S. S., 1954, Die oxydationszone sulfidischer lagerstätten; Berlin; Academie-Verlag, p. 168, 171.

Spurr, J. E., 1898, Geology of the Aspen mining district, Colorado, with atlas: U.S. Geol. Survey Mon. 31, 257 p., atlas. 1909, Ore deposition at Aspen, Colorado: Econ. Geology, v. 4, p. 301-320. 
Spurr, J. E., and Garrey, G. H., 1908, Economic geology of the Georgetown quadrangle (together with the Empire district), Colo.: U.S. Geol. Survey Prof. Paper 63, p. 138-139.

Straniero, Diego, 1954, Nossa's unique electrolytic plant extracts zinc from calamine ores : Eng. Mining Jour., v. 155, no. 5, p. 68-72.

Takahashi, Taro, 1960, Supergene alteration of zinc and lead deposits in limestone : Econ. Geology, v. 55, no. 6, p. 1083-1115.

U.S. Bureau of Mines, 1924-31, Mineral resources of the United States [annual volumes for the years indicated].

-1932-54, Minerals yearbook [annual volumes for the years indicated].

U.S. Geological Survey, 1883-1923, Mineral resources of the United States [annual volumes for the years indicated].

Untermann, G. E., and Untermann, B. R., 1954, Geology of Dinosaur National Monument and vicinity, Utah-Colorado: Utah Geol. and Mineralog. Survey Bull. 42, p. 10, 149-152.

Vanderwilt, J. W., 1935, Revision of the structure and stratigraphy of the Aspen district, Colorado, and its bearing on the ore deposits : Econ. Geology, v. 30, no. 3, p. 223-241.

1937, Geology and mineral deposits of the Snowmass Mountain area, Gunnison County, Colorado: U.S. Geol. Survey Bull. 884, p. 9-40, 100-113, 125-129, 133-134.

1947, Mineral resources of Colorado: Denver, Colo., Colorado Mineral Resources Board, $470 \mathrm{p}$.

Varnes, D. J., 1947, in Vanderwilt, J. W., Mineral resources of Colorado: Denver, Colo.; Colorado Mineral Resources Board, p. 414-416.

Volin, M. E.; and Hild, J. H., 1950, Investigation of the Smuggler lead-zinc mine, Aspen, Pitkin Gounty, Colo.: U.S. Bur. Mines Rept. Inv. 4696, 47 p.

Weed, W: H., 1920-31, The mines.handbook ; an enlargement of the copper handbook: New York, Hill Publishing Co. [annual volumes for the years indicated].

-Wendt, W. J., 1953, Ammonia-Ammonium carbonate leaching of low-grade zinc ores : Eng. Mining Jour., v. 154, no. 9, p. 84-90. 



\section{INDEX}

[Italic page numbers indicate major references]

A

Page

Abstract

Acknowledgments

Alpha-Corsair fissure zone.

American Fork district of Utah

A methyst vein.

Amothyst-Happy Thought vein

Analyses, channel sample from Carbonate district.

copper-zine material..........................

dump sample from Rico district.

gold-bearing zinc ore.

low-grade zinc-bearing material ore-pile sample from Gold Brick district zincian siderite

zinc-silver-bearing material.

Anglesite

Aragonite

Argentite

Arkansas River

Arkansas River Valley.

Asbestos

Associated minerals, list of

Associated secondary minerals, list of

Aurichalcite $10,15,24,29,31,34,44$

Azurite $13,18,29 ; 30$

B

Barite $13,17,24,26$

Barium sulfate

Belden Shale

Big stope

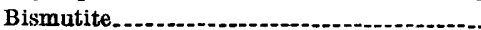

Black zinc ore

Blanket ore bodies

Breccia zone, mineralized......................... 28

Buckskin Creek

Burleigh Tunnel.

\section{$\mathbf{C}$}

Calamino. See Hemimorphite.

Calcite.

Canon City zinc-lead paint plant

Canyon Creek.

Carbonate Hill area.

Carbonate King group

Cascade Creek

Cerargyrite

Cerussite_......... 12,13,17,18, 22, 23, 25, 26, 29, 31, 33

Cerussite, silver-bearing.

Chaffee County.

descriptive summary.

Cus
. C29, 52, 53, 64,78

' Dyer Member of.......................... 20

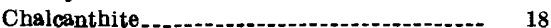

Chatcedony................. 17, 18

Chalcocite.................................... 31

Chalcophanite....................... 10,12, 19, 24, 34

Chalcopyrite.................... $8,21,30,31,32,39$

Chemistry of supergene deposition......... $\quad \$ 9$

Chicago Park prospects._.................. 72

Chrysacolla............... 30

Classification of deposits......................... $\quad 20$

Clear Creek County........... 5

Colorado Mineral Belt. ...................... 3

Copper

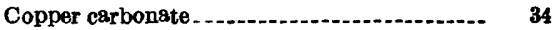

Copper sulfides................................... 29

Copper:zinedeposits. . ........ 31

Copper-zinc ore, definition.................... 45

Costilla County, descriptive summary

Cottonwood Creek

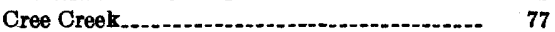

Creede Caldera.... 86,87

Cryptomelane_............. 17

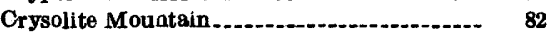

Crystal River................. 76

Cuprite . . . -

Custer County, descriptive summary _........ 84

Deposits, Rifle Creek.

Descloizite . ...................................... 16, 18

Descriptive summaries of oxidized zinc deposits............... $\quad 60$

Development and production:

Alma district._... 67

Aspen district.

Breckenridge district........................... 58

Carbonate district.............. $\quad 62$

Creede district.............................. 87

Georgetown-Silver Plume district. ......- 56

Gold Brick district............................ 73

Horseshoe district..................... 69

Ilse district........... 84

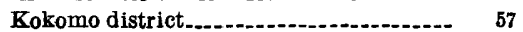

Lead ville district.............................. 62

Lenado district._._.

Malachite district............................. 56

Massadona-Younghall district............. $\quad 61$

Monarch district............................. 77

Mosquito Range district.............. 66

Red Cliff district....... 57

Rico district........... 85

Rifle Creek district............... 53 
Development and production-Continued Page Rock Creek district...................... C76

Rosita district.

Silver Cliff district...

Spring Creek district.

Sunnyside district.

Taylor Park district.

Tincup district.

Weston Pass district

Development of deposits

Dings, $M$. $A$, and Robinson, $C . S_{1}$ quoted

Dinosaur National Monument..............-. 3

Direct-replacement su

Discovery of oxidized zinc deposits........

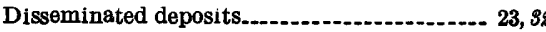

Distribution of oxidized zinc deposits......... 18

Districts:

Alma

Aspen......- 2, 5, 7, 9, 11, 15, 16, 18, 20, 26, 45, 46, 60

Breckenridge_........................ 25,42, 58

Carbonate.......................... 3,16,24,46, 62

Central City.....-....................... 15

Cotopaxi.................................. 88

Cottonwood Creek. ..................... 3,46,88

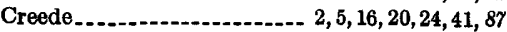

Doctor Park

Georgetown......................... 5

Georgetown-silver Plume.............. 41, 55

Gold Brick_............................ 3, 46,79

Hahns Peak ............................... 51

Horseshoe..........- 2, 5, 6, 9, 15, 20, 35, 37, 45, 69

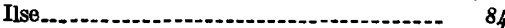

Kokomo-............. 57

Lead ville........................ 2, 5, 11,13,16,17,

$18,20,35,36,37,38,39,45,68$

Lenado........................ 2, 6, 16, 26, 45, 46, 69

Malachite.............................. 21, 38, 56

Marble_............... 46

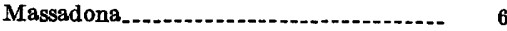

Massadona-Youghall...................... $\quad 60$

Monarch....... 2, 5, 7,9,10,15,20,35, 36,39, 45, 77

Montezuma

Mosquito Range.

Needle Mountain _ ......................... 86

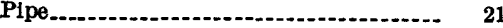

Pitkin.................. 6

Placerville

Quartz Creek

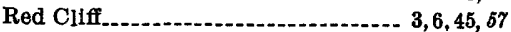

Red Mountain.............................. 86

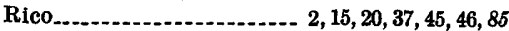

Rifle Creek ................................. 32, 59

Rock Creek. . .

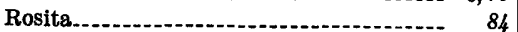

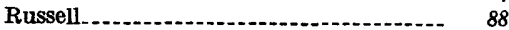

Silver Cliff............................ 3, 25, 84

Silverton ............................... 10

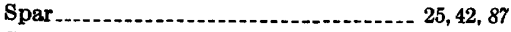

Spring Creek ............................... 2,

$5,6,7,9,17,18,20,26.28,45.46,75$

Sunnyside

86

Taylor Park

$3,46,7_{4}$

Tincup

$2,6,18,29,30,45,46,71,72$

Tomich

$2,6,35,70$
Districts-Continued Page

Turret.......... C6

Weston Pass.............................. 6, 15, 66

White Pine-Tomichi................... 46

Dolores County, descriptive summary........ 86

Downtown area of Leadville district.... 16, 45, 46, 64

Dry Canyon district of Utah................. 38

Dyer Member of the Chaffee Formation.....- 20, 69

E

Eagle County, descriptive summary .......... $\quad 57$

East No Name Creek ............... 52

Elk Mountains ............... 76

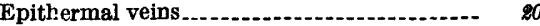

Explosion breccia

F

Ferric zinc carbonate ore.................... 35

Ferroan smithsonite......- 34

Ferroan sphalerite.............................. 32

Fieldwork

Fish Springs district of Utah .............. 30

Fluorite............... 13

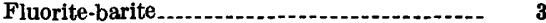

Forest Hill-Italian Mountain area

Fort Defiance...................... 52

Fort Defiance prospects .................... 53

Fremont County, descriptive summary...... 88

Fremont Limestone. . ............. 20, 64, 71, 78, 79

Front Range of Colorado................... 38

Fryer Hill area of Leadville district............ 45, 64

Fulton fault................................... 70

Future development of markets, outlook for-- $\quad 49$

Future development of reserves.............-. $\quad 46$

\section{G}

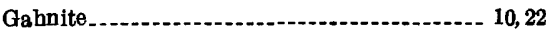

Galens_............. 9, 12, 17, 18, 26, 28, 29, 30, 31, 33

Garfield County.............................. 32

Garfield County, descriptive summary ....... $\quad 62$

Garfield group

Garfield part of Monarch district........... 24

Garnet.

Genthelvite.................................... 10

Geologic features favorablo for prospecting .... $\quad 47$

Geology and ore:

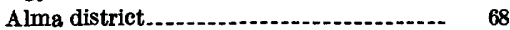

Aspen district.

Breckenridge district...................... 58

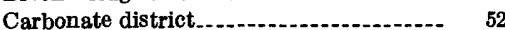

Creede district. . . . .

Georgetown-Silver Plume district......... 55

Gold Brick district........................ 73

Horseshoe district. . . . . . .

nse district....-........ 84

Kokomo district........................ 58

Leadville district............. 64

Lenado district........... 58

Malachite district.......................- 56

Massadona-Youngball district............. 51

Monarch district._........................ 78

Mosquito Range district. . ............. $\quad 66$

Red Cliff district.......... 57

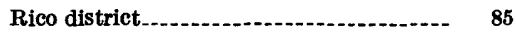

Rock Creek district. 
Rosita district..

Silver Cliff district.

Spring Creek district.

Sunnyside district.

Taylor Park district.

Tincup district.

Tomichi district...

Weston Pass district.

Goethite.

Gold.

Goslarite

Gossans

Minerals in

Granite pegmatites

Gray zinc carbonate ore

Gunnison County

descriptive summary

Gypsum.

\section{$\mathrm{H}$}

Hahns Peak

Harding Quartzite

Hells Canyon. 51

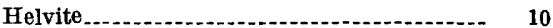

Hemimorphite. 6, 10, 12, 24, 25, 26, 29, 30, 31, 33, 34, 36

Hermosa Formation . . . .

Hetaerolite. . . . . . . .

Heterogeneous ore

History of oxidized zinc ores..............-. 2

$\mathrm{History}$ of zinc production

Horseshoe Gulch .......................... 69

Horseshoe Mountain.

Hydrohetaerolite Hydrozincite ......... 10, 12, 15, 24, 25, 30, 31, 33, 44

Hypogene deposits......................... 21, 38

Hypogene lead-zinc carbonate deposits. . ..... 22

Hypogene minerals............................ 10

\section{I}

Identification of ores, problems of ............ Investigation, previous.

Iron

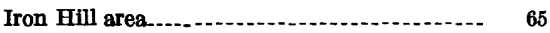

Iron vein

$24,79,82$

$\mathbf{J}$

Jarosite

$17,29,33$

Jaroso area. . . . .

Jasperoid.................................. 12, 17, 18, 24

Jefferson County, descriptive summary ....... 56

Johnson Creek . . . .

$\mathbf{K}$

Known reserves.

\section{$\mathbf{L}$}

Lake County descriptive summary.

Late stage oxidation

Lead.

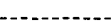

Lead arsenate

Lead carbonate deposits.

Lead carbonate pipes.

Lead King Basin.
Lead-antimony ochers..................... C25

Lead-copper sulfate.................. 31

Lead-silver carbonate ores..................... 3

Leadville, discovery of ore at................ 6

Leadville Drainage Tunnel.................. 64

Leadville Limestone ... ....................... 20 , $26,28,29,32,53,57,64,69,71,73,78$

Lead-zinc sulflde bodies.................... 26

Lead-zinc ore, definition.................. 45

Lemoigne district of California............... 43

Limonite............................ 12, 17, 24, 29, 31

List of associated minerals..................

List of primary minerals...................

List of principal secondary minerals.......... 10

Location:

Alma district_............................ 67

Ashcroft district.................... 62

Aspen district. ............................. 60

Breckenridge district.................... 58

Carbonate district........................ 52

Cottonwood Creek district................ 82

Creede district ............................ 87

Georgetown-Silver Plume district........ 55

Gold Brick district...................... 73

Hahns Peak district. .................... 51

Horseshoe district. . ... .

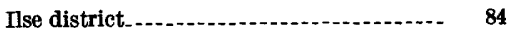

Kokomo district.-.............. 57

Leadville district....................... 62

Lenado district.

Malachite district......................... 56

Massadona-Younghall district............ $\quad 50$

Monarch district.............. $\quad 77$

Montezuma district.

Mosquito Range district._..._............ 65

Needle Mountain district._.............. $\quad 86$

Placerville district......................... 84

Quartz Creek district._._................. 71

Red Cliff district......................... 57

Red Mountain district._.

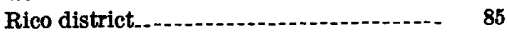

Rifle Creek district.

Rock Creek district. ... . .

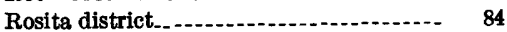

Silver Cliff district....................... 84

Spring Creek district..................... 75

Sunnyside district............ 86

Taylor Park district._................... 74

Tincup district.

Tomichi district........ 70

Weston Pass district.

Loughlin, G. F., quoted

Loveland Mountain

Lower New York Tunnel. . . .

Low-grade material, definition............ 45

Low-grade oxidized zinc ore.................. 5

Low-temperature epithermal deposit. . . ...... 33
5

\section{M}

Madonna fault............................ 79

Magnetite...

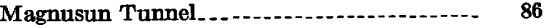

Main oval limestone belt.

Malachite........................ 13, 17, 18, 29, 30, 31

Mancos Shale.....

Manganese_._._....................... 12, 26, 28, 34 


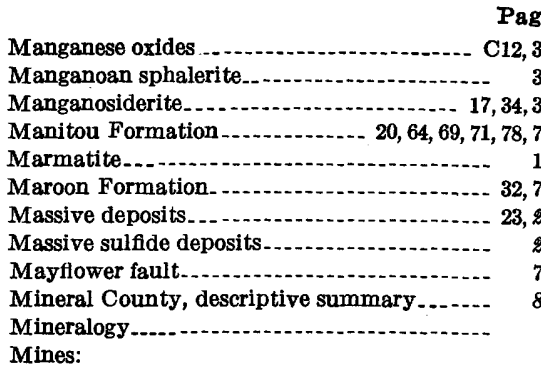

Akron.

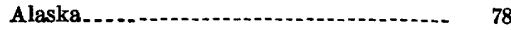
Amethyst-Happy Thought_.......... 87

Annie Hudson.

Aspen Contact. . Augusta...... 3, 13, 56

Bassick............ 84

Belle Champion........... 85

Bird Creek.

Black Iron Mask. .

Blackhawke......... 82

Bon Ton........ 10, 22, 77

Breadwinner...... 71

Bull Domingo . .

Campbell._...... 66

Carbonate Hill.

Carbonate King.

Chrysolite........ 36

Cincinnati..._. 66

Colin....... 66

Continental Chief. .

Cotopaxi........ 10, 22,83

Cree Camp..... 46

Creet.-....... 30

Criterion........ 68

David H_........ 71

Defender..................... 3, 84

Denver City...._._._. 71

Doctor ................ 6, 15, 17, 18, 28, 46, 75

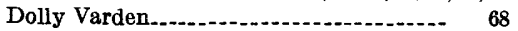

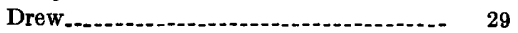

Dyer......... 66

Eagle Lead Bullet_................... 77

Eclipse................ 6, 36, 46, 77, 78, 79, 81

El Capitan.

F. M. D.

Fairplay

Flossie D

Garfield. ....... 78, 79

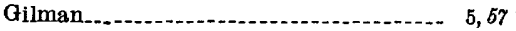

Gold Cup Republic_._._._. 29, 72

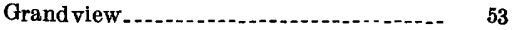

Great Monarch _........ 6,77, 78

Great Western....................... 60

Hawkeye.............. 35, 46, 78, 79, 81

Helena.

Hill Top................... 6, 37,69

Ilse._...

Iron Chest._._.

Jones_._._._. 15

King Solomon-Holy Moses............ 87

Kokomo Metals._.....

Lark _......... 3, 10,22, 23, 38

Lead King.
Mines-Continued Page

Legal Tender......... C71

Liddia. ....... 66

Lilly.

Little Claim ........ 78

Little Giant._. 78

London. . . . 67

Madonna............. 6, 46, 77, 78, 79, 81

Maid of Athens. . . 71

Mantle._........... 15, 25, 41, 50

Mary Holbrook.

Mary Murphy.

May Green....... 6

Molly Gibson.

Monarch Pool............... 67, 78

Montezuma.

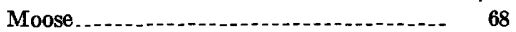

Morning Star...... 6, 70,71

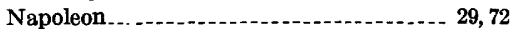

Nelson. . .

New York .......... 46, 78, 79

Ora La Plata.

Orphan Boy

Paymaster.

Robert E. Lee..... 29

Ruby. . . 66

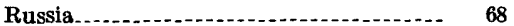

Sedalia. _ 2 2, 3, 5, 6, 10, 11, 12, 15, 20, 22, 31, 39, 42, 83

Silent Friend........... 6, 46, 71, 78, 79, 81

Silver Cup. ............... 29

Silver Hoard. . .

Silver Islet. . .

Smuggler........... 5

Smuggler-Molly Gibson. .

Star.

Sunshine Lode. ...

Terrible._._. 84

Tincup._._. 29

Victor.

Wilson. . . . .

Windy Point............. 52

Wolfton.......... 13

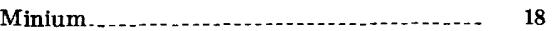

Minturn Formation

Mississippi Valley zinc districts. . . . . . .

Mitchell Creek....... 52

Mode of occurrence of oxidized zinc deposits.- $\quad 18$

Moffat County, descriptive summary . ...... $\quad 50$

Molybdenite. ...

Monarch group........ 77

Monarch Pass........ 2

Monarch quadrangle..................... 2

Monarch Ridge . . . . 77

Monheimite. 11,22

Morrison Formation. . .

Mosquito Range . . . . _ . 15, 65, 69

Mount Bross... 3,67

Mount Lincoln.

Mount Princeton Quartz Monzonite. ...... 82

Mount Sheridan._._. 69

Mount Sherman ...

Native gold

Native silver.

Needle Mountain. . . .

New York Tunnel. 24 


Nicholsonite...
Nigger Baby Hill.
North Italian Mountain....

\section{o}

Oasis Creek

Opaline jasper.

Ophir district of Utah.

Ore, definition.

Ore resources:

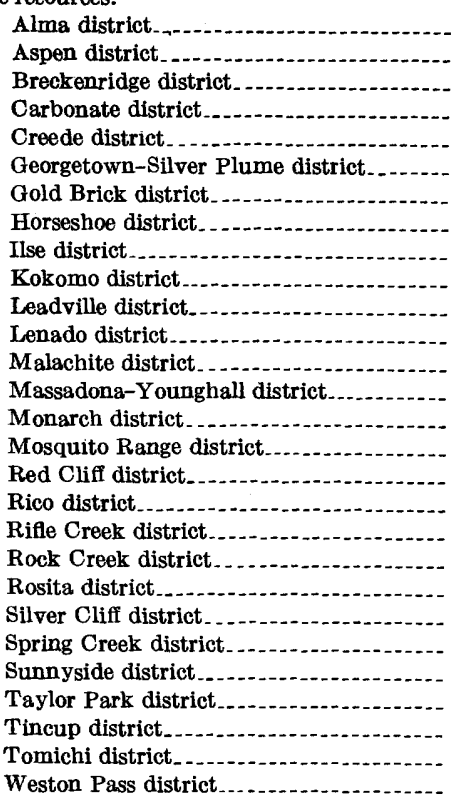

Origin of deposits.........................

Origin of ore in Sedalia mine.

Ouray.

Outlook for future development of markets...

Oxidized, defined.

Oxidized zinc minerals

Oxidizing agents.

Oxidizing solvents.

\section{$\mathbf{P}$}

Park City district of Utah.

Park County, descriptive summary

Parting Quartzite

Phosgenite

Pitkin County, descriptive summary

Plumbojarosite.

Pocket ore bodies.....................

Polybasite

Potential, definition .........................

Precambrian gneisses and schists

Precambrian schists.

Previous reports on

Primary minerals, list of -.................

Primary zine minerals.

Principal known zine deposits, location.-...-...

Principal secondary zinc minerals, list
Page

C16

85,86

74

Problems of identification of ores

Production.

Production of oxjdized zinc ores, publication

$$
\text { of - }
$$

Productive oxidized zinc deposits, location.... 


\section{INDEX}

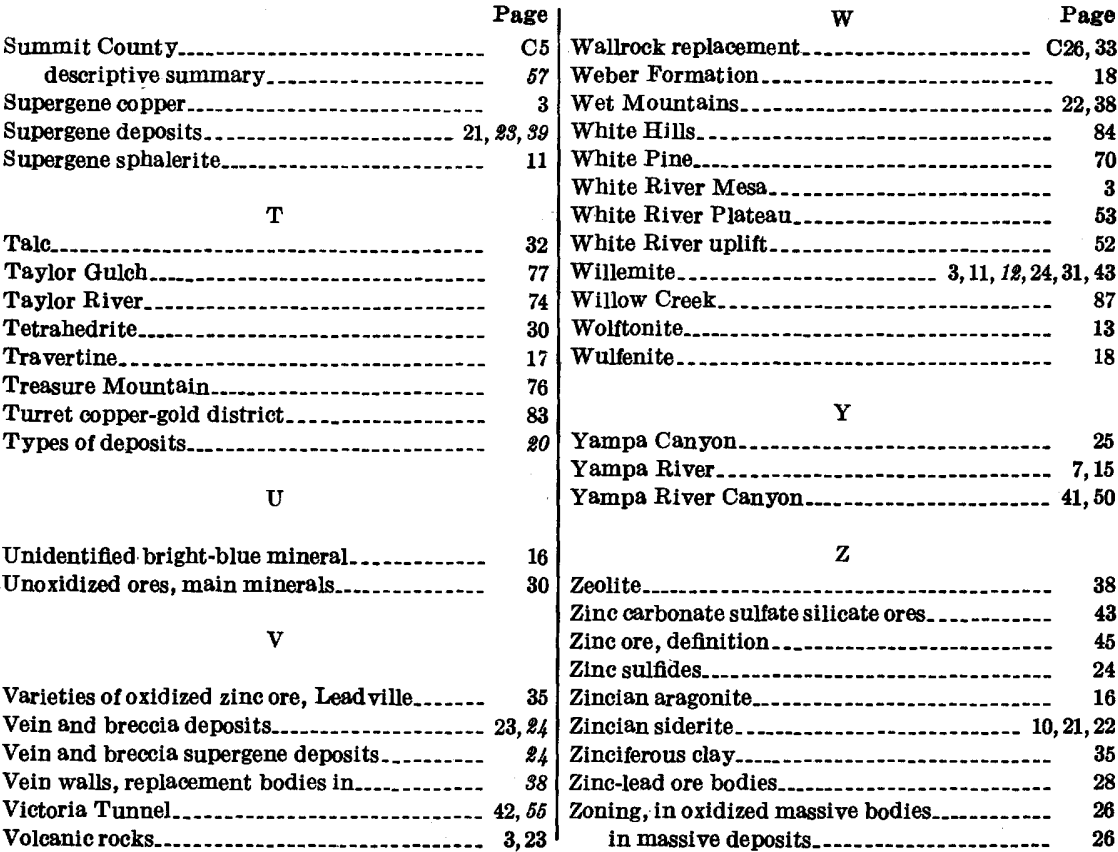

